Effects of Groundwater Withdrawal on Borehole Flow and Salinity Measured in Deep Monitor Wells in Hawai' $i-$ Implications for Groundwater Management

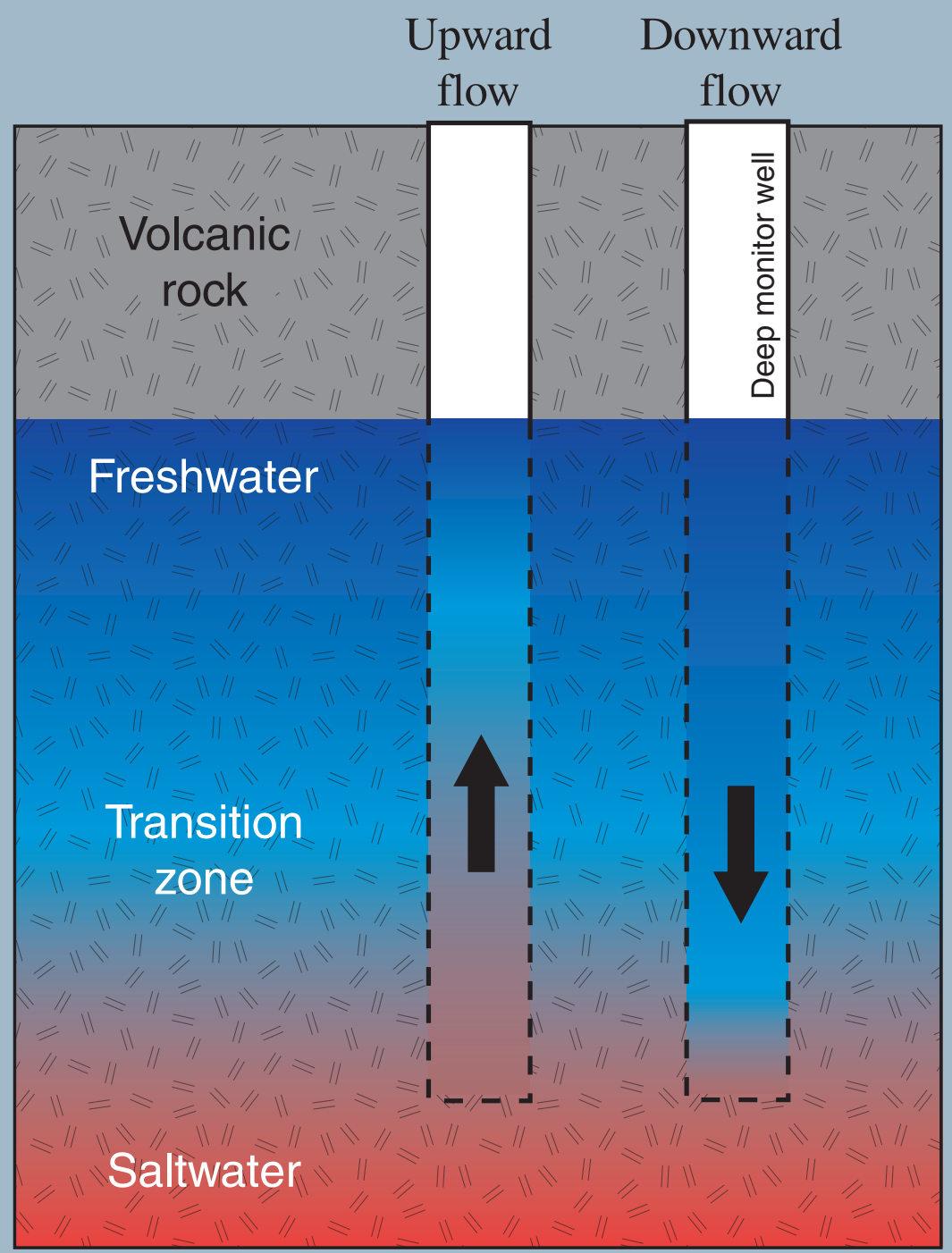

Scientific Investigations Report 2010-5058 


\section{FRONT COVER}

Schematic cross section of deep monitor wells penetrating through the freshwater lens into the underlying saltwater in a volcanic-rock aquifer, showing how upward and downward borehole flow affects the salinity distribution with depth in the wells. 


\section{Effects of Groundwater Withdrawal on Borehole Flow and Salinity Measured in Deep Monitor Wells in Hawai'i- Implications for Groundwater Management}

By Kolja Rotzoll

Scientific Investigations Report 2010-5058 


\section{U.S. Department of the Interior \\ KEN SALAZAR, Secretary \\ U.S. Geological Survey \\ Marcia K. McNutt, Director}

\section{U.S. Geological Survey, Reston, Virginia: 2010}

This report and any updates to it are available online at: http://pubs.usgs.gov/sir/2010/5058/

For more information on the USGS - the Federal source for science about the Earth, its natural and living resources, natural hazards, and the environment, visit http://www.usgs.gov or call 1-888-ASK-USGS

For an overview of USGS information products, including maps, imagery, and publications, visit http://www.usgs.gov/pubprod

To order this and other USGS information products, visit http://store.usgs.gov

Any use of trade, product, or firm names is for descriptive purposes only and does not imply endorsement by the U.S. Government.

Although this report is in the public domain, permission must be secured from the individual copyright owners to reproduce any copyrighted materials contained within this report.

Suggested citation:

Rotzoll, Kolja, 2010, Effects of groundwater withdrawal on borehole flow and salinity measured in deep monitor wells in Hawai' $i$-implications for groundwater management: U.S. Geological Survey Scientific Investigations Report 2010-5058, 42 p. 


\section{Executive Summary}

Vertical salinity profiles measured in deep monitor wells commonly are used to estimate the volume of freshwater in aquifers in Hawai' $i$. Water-resource managers use information from salinity profiles to monitor changes in the freshwater volume over time and determine appropriate groundwater withdrawal rates. Natural or anthropogenic factors can cause water in deep monitor wells to flow vertically within the borehole, and this may cause the observed salinity distribution in the monitor well to be a poor indicator of the salinity distribution in the aquifer, resulting in an underestimation or overestimation of the volume of freshwater stored in an aquifer. Thus, a better understanding of how borehole flow affects the measured vertical distribution of salinity in monitor wells is needed for proper analysis and interpretation of vertical salinity profiles and sound management of the groundwater resources.

\section{Indicators of Borehole Flow}

Salinity profiles from paired shallow and deep monitor wells may differ over the common depth interval of the wells. Observed differences can be explained by borehole flow moving brackish water upward in the deep well, an interpretation supported by flow measurements. Additionally, steplike changes in salinity or temperature with depth may be indicative of borehole flow over a discrete depth interval, and such changes are evident to some extent in all available profiles. Vertical flow may affect hundreds of feet of a salinity profile, and this occurs commonly in monitor wells located in southern O'ahu. Steplike changes in salinity that do not affect long sections (less than $70 \mathrm{ft}$ ) of a profile may be related more to the presence of low-permeability massive rock layers in the aquifer than to borehole flow.

\section{Effects of Withdrawals on Salinity in Boreholes}

Although groundwater withdrawals have caused a regional thinning of the freshwater lens over the past several decades in southern $\mathrm{O}$ 'ahu, the apparent midpoint of the transition zone between freshwater and saltwater in most deep monitor wells has shown only inconsequential depth displacement related to borehole flow caused by short-term variations in nearby groundwater withdrawals. In contrast, the apparent top of the transition zone, indicated by a specific-conductance value of $1,000 \mu \mathrm{S} / \mathrm{cm}$, has risen several hundred feet in some deep monitor wells because of borehole flow induced by withdrawals from nearby production wells (fig. ES1). Some deep monitor wells are affected by borehole flow over sections longer than $70 \mathrm{ft}$, but currently the apparent top of the transition zone is not within the longest vertical step in the salinity profile (yellow triangles in fig. ES1). The vertical step is characterized by nearly constant salinity over the interval affected by borehole flow. However, no significant relation is evident between proximity of production wells to monitor wells and length of vertical step. In some deep monitor wells near production wells, the salinity value within a vertical step in the measured salinity profile may vary in response to withdrawal rate. In deep monitor wells that are distant from production wells but within compartmentalized aquifers, the salinity value within a vertical step in the measured profile may be related to regional withdrawals.

\section{Groundwater Management Implications}

Vertical steps in salinity measured in deep monitor wells are indicative of borehole flow that can cause the measured top of the transition zone in the borehole to rise several hundred feet compared to the top of the transition zone in the aquifer. This may result in an underestimation of the volume of freshwater in groundwater storage. The longest vertical steps in salinity occur in monitor wells located in southern O'ahu, coinciding with the most heavily developed part of the aquifer. Here, the measured top of the transition zone in boreholes may be a poor indicator of the freshwaterlens thickness (fig. ES1). In general, the measured midpoint of the transition zone in a borehole is a better proxy for freshwater-lens thickness than the measured top. Moreover, brackish water flowing upward in deep monitor wells may exit the borehole in the upper part of the aquifer containing freshwater, which can affect the quality of water pumped by nearby production wells.

For deep monitor wells with profiles that are affected by nearby withdrawals from production wells, collecting salinity profiles under consistent withdrawal conditions will facilitate comparisons of profiles over time. Piezometers installed at different depths will provide the best information on aquifer salinity, because they are unaffected by borehole flow. 


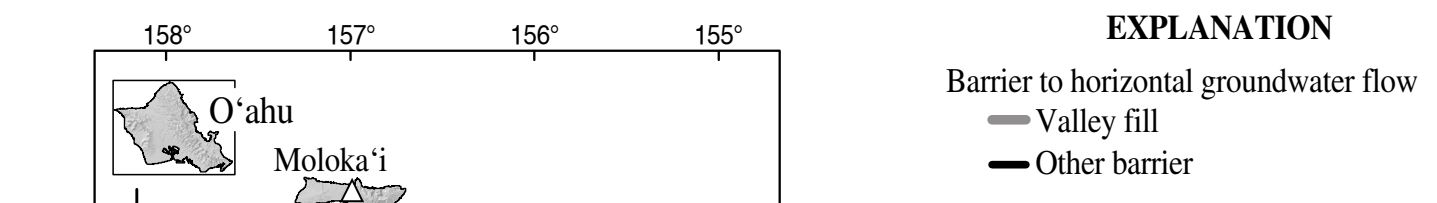

Maximum length of vertical displacement (step) in measured salinity profile, in feet

\section{$\triangle$ Longest step is less than $\mathbf{7 0}$ feet} Longest step is greater than $\mathbf{7 0}$ feet

$\triangle$ Apparent top of transition zone is within the largest step

$\triangle$ Apparent top of transition zone is currently not within the largest step

Mean withdrawal 1996-2005, in million gallons per day

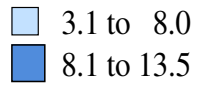

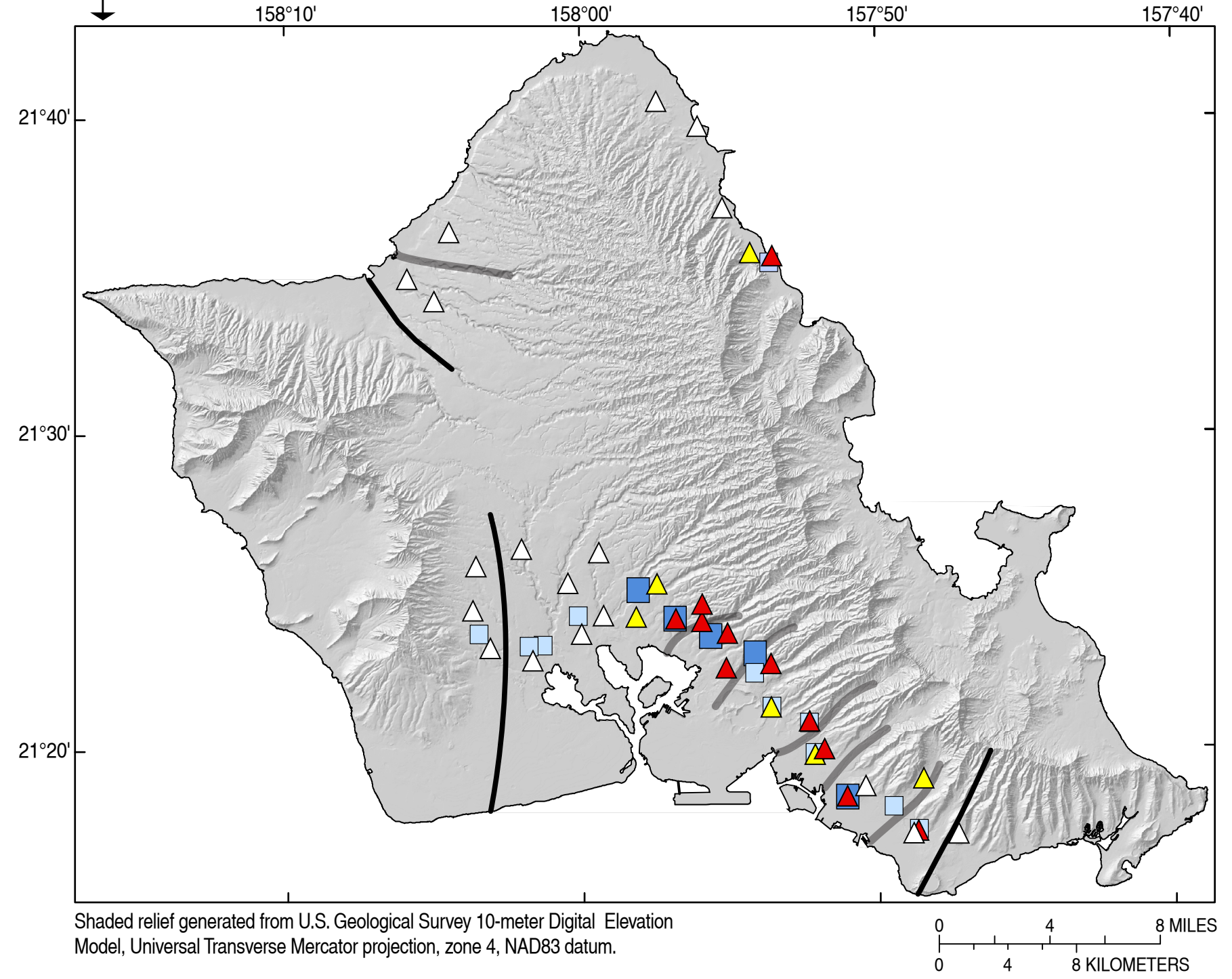

Figure ES1. Vertical steps in measured salinity profiles in Hawaii and their relation to the apparent top of the freshwater-saltwater transition zone, which is defined as having a specific conductance of 1,000 microsiemens per centimeter. Vertical steps longer than 70 feet can indicate borehole flow that may be related to nearby withdrawal or other factors, including regional drawdown in compartmentalized aquifers and natural hydraulic gradients at depth. Mean groundwater withdrawal rates are for wellfields. 


\section{Contents}

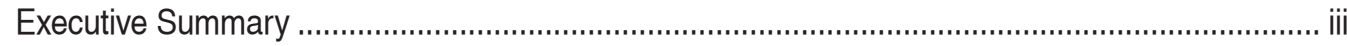

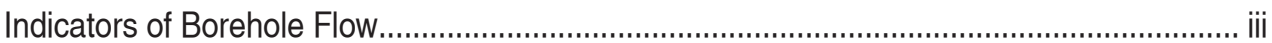

Effects of Withdrawals on Salinity in Boreholes ............................................................. ii

Groundwater Management Implications ............................................................................ iii

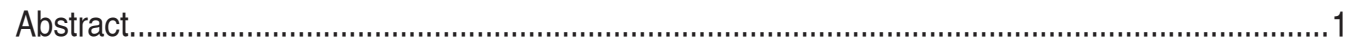

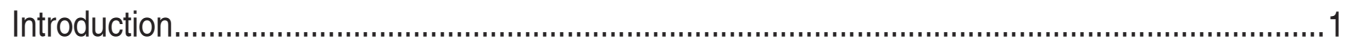

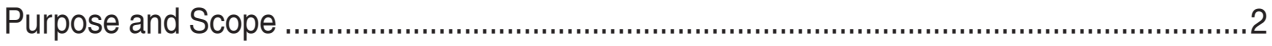

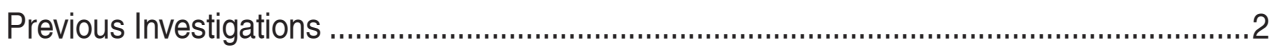

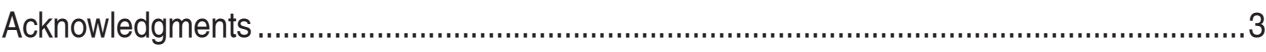

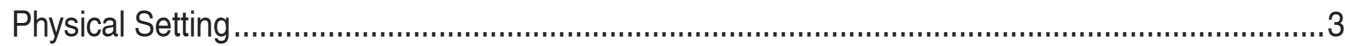

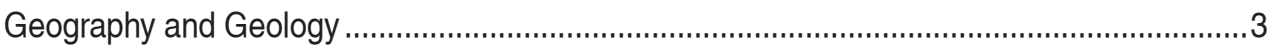

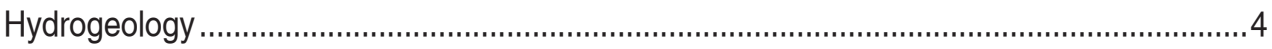

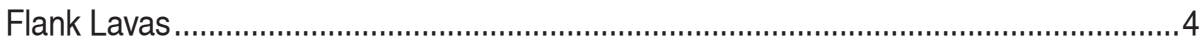

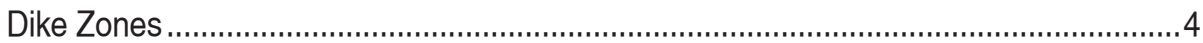

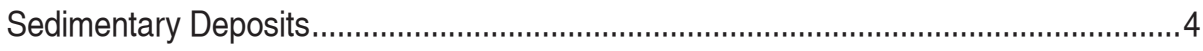

Groundwater Dynamics in the Freshwater Lens ...........................................................

General Characteristics of Salinity Profiles and Deep Monitor Wells............................................

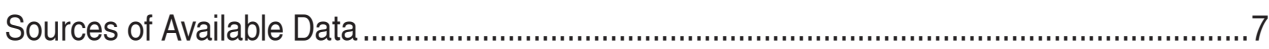

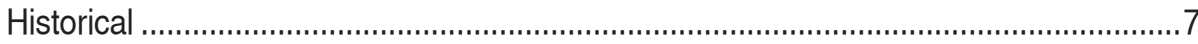

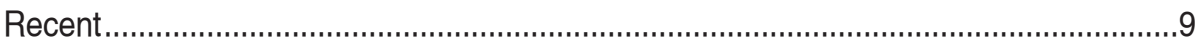

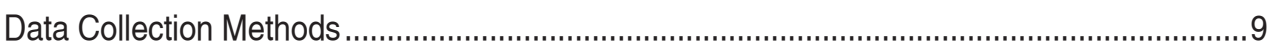

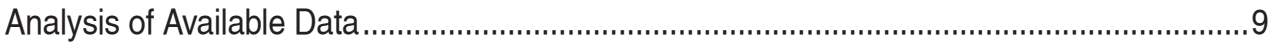

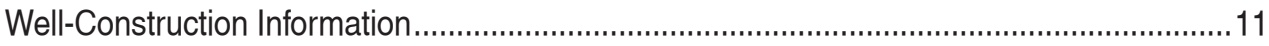

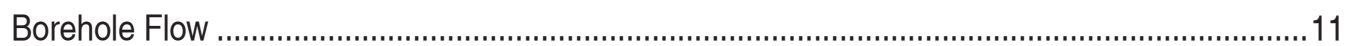

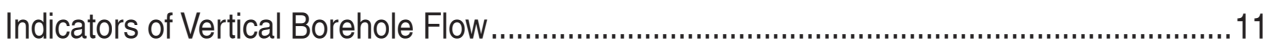

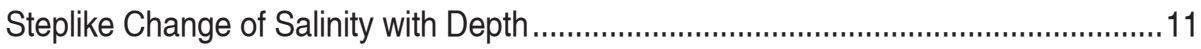

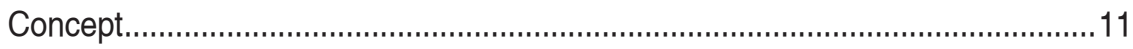

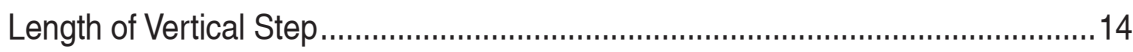

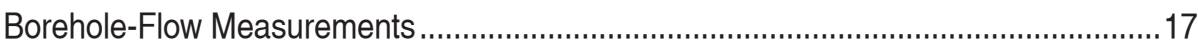

Monitor Wells Near Production Wells..........................................................17

Monitor Wells Distant from Production Wells ........................................................17

Comparison of Salinity and Temperature Profiles from Shallow and Deep Wells.......... 18

Effects of Groundwater Withdrawal on Salinity Profiles ..................................................21

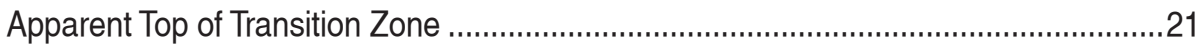

Apparent Top of Transition Zone Not Included Within the Longest

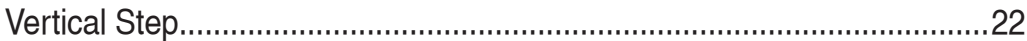

Apparent Top of Transition Zone Included Within the Longest Vertical Step .........24

Apparent Midpoint of Transition Zone ..................................................................... 30

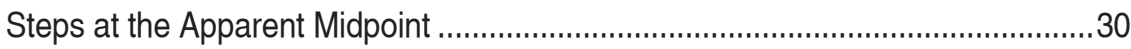

Relation Between Daily Withdrawal Rates and Apparent Midpoint of Transition

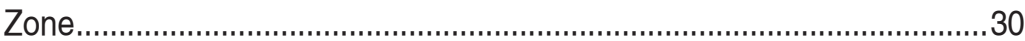

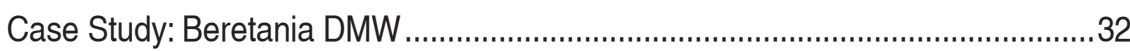




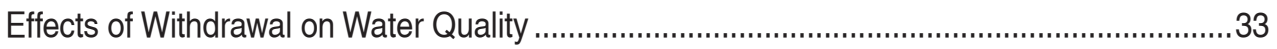

Deep Monitor Wells Acting as Brackish-Water Conduits .............................................33

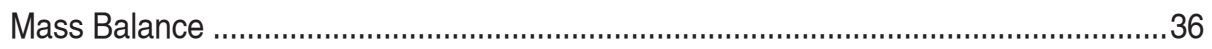

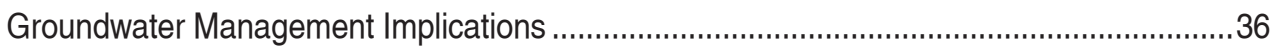

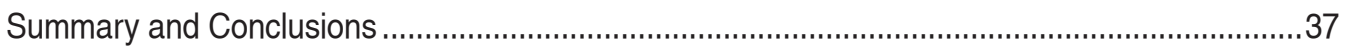

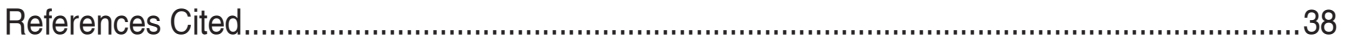

\section{Figures}

ES1. Vertical steps in measured salinity profiles in Hawai'i.................................................. iv

1. Location of deep monitor wells that penetrate through the transition zone .........................6

2. Generalized diagram of the groundwater flow pattern in a freshwater-lens system.............7

3. Locations and names of selected wells mentioned in the text, Island of O'ahu ...................8

4. Salinity-depth profile of Kahului Fairgrounds Well, central Maui, Hawai'i .............................

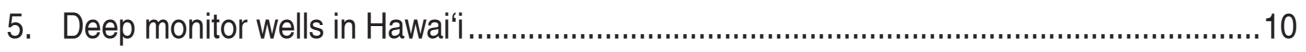

6. Diagrams of conceptual salinity profiles of different shapes in a borehole........................13

7. Salinity profile in South Hālawa DMW on 09/13/2001 ...................................................14

8. Maximum length of vertical step in measured salinity profiles in Hawaii ..........................15

9. Specific-conductance, borehole diameter (caliper), and flowmeter measurements...........18

10. Specific-conductance, borehole diameter (caliper), and flowmeter measurements...........19

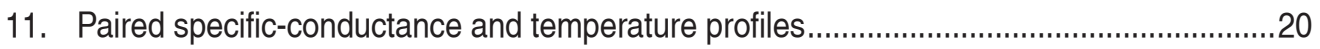

12. Salinity $(A)$ and temperature $(B)$ profiles obtained in Punanani DMW .............................21

13. Selected profiles in which the longest vertical step in salinity does not include the 1,000 microsiemens per centimeter specific-conductance value .............................23

14. Selected profiles in which the longest vertical step in salinity includes the 1,000 microsiemens per centimeter specific-conductance value ............................25

15. Selected profiles in which the longest vertical step in salinity, induced by nearby or regional withdrawal, is persistent......................................................................27

16. Maximum length of vertical step in measured salinity profiles from deep monitor wells in

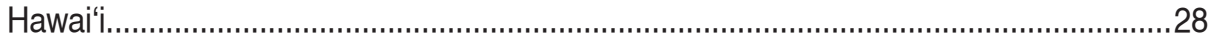

17. Changes from 1968 to 2009 in the depths of the apparent top and midpoint of the transition zone between fresh and saltwater.

18. Influence of natural and human-induced stresses on the salinity profile in a deep monitor well.......

19. Observed and estimated specific-conductance changes and relative vertical displacement of the apparent midpoint of the transition zone in Beretania DMW..........32

20. Conceptual cross section between production well and nearby monitor well .....................34

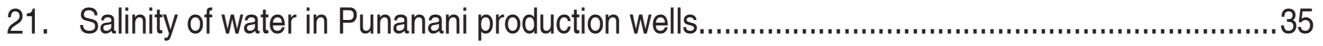

22. Salinity of water from point piezometers through the freshwater-saltwater transition zone in Kawailoa Pump 4 


\section{Tables}

1. Salinity of the top and midpoint of the freshwater-saltwater transition zone.............................

2. Characteristics of deep monitor wells and summary of available salinity and temperature profiles used in this study. 12

3. Specifications of the maximum vertical step of measured salinity. 16

4. Effect of stresses from ocean tides, barometric pressure, and nearby groundwater withdrawals.

\section{Conversion Factors}

Inch/Pound to SI

\begin{tabular}{|c|c|c|}
\hline Multiply & By & To obtain \\
\hline \multicolumn{3}{|c|}{ Length } \\
\hline inch (in.) & 2.54 & centimeter $(\mathrm{cm})$ \\
\hline inch (in.) & 25.4 & millimeter $(\mathrm{mm})$ \\
\hline foot $(\mathrm{ft})$ & 0.3048 & meter $(\mathrm{m})$ \\
\hline mile (mi) & 1.609 & kilometer $(\mathrm{km})$ \\
\hline \multicolumn{3}{|c|}{ Volume } \\
\hline gallon (gal) & 3.785 & liter (L) \\
\hline gallon (gal) & 0.003785 & cubic meter $\left(\mathrm{m}^{3}\right)$ \\
\hline gallon (gal) & 3.785 & cubic decimeter $\left(\mathrm{dm}^{3}\right)$ \\
\hline million gallons (Mgal) & 3,785 & cubic meter $\left(\mathrm{m}^{3}\right)$ \\
\hline \multicolumn{3}{|c|}{ Flow rate } \\
\hline foot per minute ( $\mathrm{ft} / \mathrm{min})$ & 0.3048 & meter per minute $(\mathrm{m} / \mathrm{min})$ \\
\hline foot per day $(\mathrm{ft} / \mathrm{d})$ & 0.3048 & meter per day $(\mathrm{m} / \mathrm{d})$ \\
\hline gallon per day (gal/d) & 0.003785 & cubic meter per day $\left(\mathrm{m}^{3} / \mathrm{d}\right)$ \\
\hline million gallons per day $(\mathrm{Mgal} / \mathrm{d})$ & 0.04381 & cubic meter per second $\left(\mathrm{m}^{3} / \mathrm{s}\right)$ \\
\hline \multicolumn{3}{|c|}{ Hydraulic conductivity } \\
\hline foot per day $(\mathrm{ft} / \mathrm{d})$ & 0.3048 & meter per day $(\mathrm{m} / \mathrm{d})$ \\
\hline \multicolumn{3}{|c|}{ Hydraulic gradient } \\
\hline foot per mile $(\mathrm{ft} / \mathrm{mi})$ & 0.1894 & meter per kilometer $(\mathrm{m} / \mathrm{km})$ \\
\hline
\end{tabular}

Temperature in degrees Celsius $\left({ }^{\circ} \mathrm{C}\right)$ may be converted to degrees Fahrenheit $\left({ }^{\circ} \mathrm{F}\right)$ as follows: ${ }^{\circ} \mathrm{F}=\left(1.8 \times{ }^{\circ} \mathrm{C}\right)+32$

Horizontal coordinate information is referenced to the North American Datum of 1983 (NAD 83).

Vertical coordinate information is referenced in feet relative to mean sea level. Altitude, as used in this report, refers to distance above the vertical datum.

Specific conductance is given either in microsiemens per centimeter at 25 degrees Celsius $(\mu \mathrm{S} / \mathrm{cm})$ or millisiemens per centimeter at 25 degrees Celsius $(\mathrm{mS} / \mathrm{cm})$.

Concentrations of chemical constituents in water are given in milligrams per liter $(\mathrm{mg} / \mathrm{L})$. 
This page left intentionally blank. 


\title{
Effects of Groundwater Withdrawal on Borehole Flow and Salinity Measured in Deep Monitor Wells in Hawai'i- Implications for Groundwater Management
}

\author{
By Kolja Rotzoll'
}

\section{Abstract}

Water-resource managers in Hawai 'i rely heavily on salinity profiles from deep monitor wells to estimate the thickness of freshwater and the depth to the midpoint of the transition zone between freshwater and saltwater in freshwater-lens systems. The deep monitor wells are typically open boreholes below the water table and extend hundreds of feet below sea level. Because of possible borehole-flow effects, there is concern that salinity profiles measured in these wells may not accurately reflect the salinity distribution in the aquifer and consequently lead to misinterpretations that adversely affect water-resource management.

Steplike changes in salinity or temperature with depth in measured profiles from nonpumped deep monitor wells may be indicative of water moving within the well, and such changes are evident to some extent in all available profiles. The maximum vertical step length, or displacement, in measured profiles ranges from 7 to 644 feet. Vertical steps longer than 70 feet exceed the typical thickness of massive lava flows; they therefore cannot be attributed entirely to geologic structure and may be indicative of borehole flow. The longest vertical steps occur in monitor wells located in southern O'ahu, coinciding with the most heavily developed part of the aquifer.

Although regional groundwater withdrawals have caused a thinning of the freshwater lens over the past several decades, the measured midpoint of the transition zone in most deep monitor wells has shown only inconsequential depth displacement in direct response to short-term variations in withdrawals from nearby production wells. For profiles from some deep monitor wells, however, the depth of the measured top of the transition zone, indicated by a specific-conductance value of 1,000 microsiemens per centimeter, has risen several hundred feet in response to withdrawals from nearby production wells. For these deep monitor wells, monitoring the apparent top of the transition zone may not provide an accurate indication of water quality in the adjacent aquifer. Hence, the measured midpoint in boreholes is a better proxy for freshwater-lens thickness.

\footnotetext{
${ }^{1}$ University of Hawai ‘i at Mānoa, Water Resources Research Center
}

Brackish water transported upward in a deep monitor well can exit the borehole in the upper, freshwater part of the aquifer and affect the water quality in nearby production wells. Piezometers installed at different depths will provide the best information on aquifer salinity because they are unaffected by borehole flow. Despite the effects of borehole flow, monitoring the midpoint in deep monitor wells is still useful to identify long-term trends in the movement of the transition zone.

\section{Introduction}

In Hawai ' $i$, dozens of deep monitor wells (DMWs) have been drilled to provide an indication of how groundwater salinity varies with depth. The deep wells penetrate entirely through the freshwater zone and partly or entirely through the brackish-water transition zone that separates freshwater from underlying higher density saltwater in a freshwater-lens system. DMWs typically are constructed as open (uncased) boreholes or are cased with slotted casing that allows water from the aquifer to readily enter the well. Salinity profiles measured in DMWs typically are used to estimate the thickness of the freshwater lens in volcanic-rock aquifers in Hawai ' $i$ under the assumption that the measured vertical distribution of salinity in the borehole is representative of salinity in the adjacent aquifer. However, vertical flow can displace water inside the monitor well so that the observed salinity in the borehole may not accurately reflect the salinity distribution in the aquifer. This can lead to misinterpretations that adversely affect water-resource management. Groundwater provides almost all drinking water and more than half of freshwater for other uses in Hawai 'i (Gingerich and Oki, 2000). Decisions related to future infrastructure development and alternate sources of freshwater, including desalinization, will depend on the long-term sustainability of groundwater resources. It is therefore critically important, from economic and resource perspectives, to have an accurate understanding of the volume of fresh groundwater stored in aquifers and how it is changing in response to changes in recharge and withdrawal.

The status of fresh groundwater resources in Hawai $i$ commonly is assessed through vertical profiles of salinity collected from DMWs. The profiles provide information on 
the thickness of the freshwater zone at the time the profile is collected. Furthermore, monitoring over time provides information on how the freshwater thickness changes as a result of changes in groundwater withdrawals or recharge. By monitoring changes in the freshwater thickness in DMWs over time, water managers can determine appropriate withdrawal rates from production wells. The State of Hawai 'i Commission on Water Resource Management (CWRM) uses the Robust Analytical Model (Mink, 1980, 1981) and the Robust Analytical Model 2 (RAM2) (Liu, 2006, 2007) for estimating the amount of groundwater that can be withdrawn from aquifer systems in the State. RAM2 incorporates information from salinity profiles to estimate sustainable withdrawal rates. Vertical salinity profiles also represent valuable data for calibration of numerical groundwater models designed to simulate density-dependent groundwater flow and transport in coastal aquifers (Voss and Souza, 1987; Oki and others, 1998). These models provide insights into groundwater availability under different recharge and withdrawal scenarios (Oki, 2005; Gingerich, 2008) and are useful tools for managing groundwater resources.

The underlying assumption in using salinity profiles from DMWs is that the measured vertical distribution of salinity in the borehole is representative of salinity in the adjacent aquifer. However, natural or anthropogenically induced vertical hydraulic gradients in the aquifer can generate flow in the borehole. Complex flow patterns may exist in some boreholes in Hawai 'i (Paillet and Hess, 1995). Flow within a monitor well causes water that entered the borehole in one interval to be present in another interval, and thus the salinity profile obtained from a monitor well may not be representative of salinity in the adjacent aquifer. For cases in which upward flow exists in a borehole, brackish water or saltwater entering the borehole from deeper zones can lead to overestimation of salinity in the adjacent aquifer in shallower zones. In contrast, for cases in which downward flow exists, freshwater entering the borehole from shallow zones can lead to underestimation of salinity in the adjacent aquifer in deeper zones. All other factors being equal, higher rates of borehole flow will have a greater effect on the measured salinity profile (Paillet and others, 2002).

Presently (2010), 48 DMWs exist in Hawai 'i, of which 40 are monitored on a routine basis by the Honolulu Board of Water Supply (HBWS), CWRM, U.S. Geological Survey (USGS), National Park Service (NPS), and other private entities. Although various instruments have been used in the past, presently most of the profiles are measured using a multiparameter probe that measures fluid electrical conductivity (as a proxy for salinity), temperature, and pressure as the probe is lowered through the water column.

In 2007, with support from Congress and in collaboration with the CWRM, HBWS, and the Water Resources Research Center of the University of Hawai ' $i$, the USGS initiated an investigation to evaluate the effects of borehole flow on measured salinity profiles in DMWs. The concern was that inaccurate or misleading information on aquifer salinity could adversely affect groundwater management. This study focuses on the effects of groundwater withdrawal on DMWs. Some of the questions addressed by this study include: (1) Does borehole flow occur in all DMWs? (2) What are the indicators of borehole flow? (3) What are the effects of nearby withdrawal on DMWs? (4) Which DMWs are strongly affected by borehole flow? (5) What are the ramifications of borehole-flow effects for groundwater management?

\section{Purpose and Scope}

This report presents evidence for borehole flow in DMWs, explains some of the possible effects of nearby groundwater withdrawals on measured salinity profiles, and discusses implications for water-resource management in Hawai ${ }^{\prime}$ i. This study reviews and evaluates 797 salinity profiles from 42 DMWs and reviews vertical flow measurements in 4 DMWs. The geographic focus of the study is on the most developed aquifer systems in Hawai $i$ - the Honolulu-Pearl Harbor area on $\mathrm{O}^{\prime}$ ahu and the Wailuku area on Maui.

\section{Previous Investigations}

Borehole geophysical logging in Hawai ' $i$ has shown evidence of borehole flow in some cases (Paillet and Hess, 1995; Paillet and others, 2002). Although this phenomenon has been recognized for more than 20 years (for example, Eyre, 1987; Souza and Meyer, 1995; Meyer and Presley, 2001; Oki, 2002), it has not been comprehensively addressed in published literature. As a result of possible borehole-flow effects, salinity profiles from monitor wells may not accurately reflect the salinity distribution in the surrounding aquifer (Paillet and Hess, 1995). Underwood and others (1995) stated that if upward borehole flow exists, salinity profiles would tend to indicate a thinner freshwater zone than exists in the aquifer. Voss and Wood (1994) concluded that borehole flow may affect local sections of the profile that are as much as $66 \mathrm{ft}$ long, although salinity measurements on the scale of the entire profile generally are representative of water quality in the aquifer. Paillet and others (2002) found electrical-conductivity profiles of the fluid column generally similar to that of the groundwater in the adjacent formation by comparing them to induction logs. Vertical flow was observed in the Waipi'o Mauka DMW (fig. 1), and complex flow patterns were observed in boreholes near Waipahu DMW, O'ahu, and the east side of the Island of Hawai ' $i$ (Paillet and Hess, 1995). Borehole flow also was observed in the Kaimuki Station DMW (fig. 1) (Paillet and others, 2002). The flow and the salinity in the well both increased in the Kaimuki Station DMW when the withdrawal rate from the nearby production wellfield doubled. Causes of borehole flow and the effects of borehole flow on vertical salinity profiles in coastal aquifers in Hawai ' $i$ and Guam have been addressed by Oki and Presley (2008).

Borehole flow can influence the reliability of groundwater quality samples collected from monitor wells (Giddings, 1987). Since the late 1980s, the use of long-screened boreholes (hundreds of feet) for groundwater sampling has been 
discouraged in many studies because water samples obtained from them are not representative of water in the adjacent aquifer (for example, Shosky, 1987; Reilly and others, 1989; Robbins, 1989). Vertical borehole flow can occur in a longscreened monitor well because of a natural hydraulic gradient with depth (Church and Granato, 1996). This flow also could act as a conduit for contaminants (Lacombe and others, 1995). In long-screened wells in a sandy aquifer in France, sampling for groundwater age at discrete depths was biased by ambient vertical flow (Corcho Alvarado and others, 2009). A sand-tank model study indicated that a long-screened well can create an artifact even in the absence of vertical ambient flow and that water-quality stratification in a borehole may not correspond to stratification in the aquifer (Britt, 2005). Sukop (2000) used a simple solute mass-balance and water-balance method to compute the vertical distribution of solute concentration in the aquifer using water-quality information from a long-screened monitor well. Applying this mass balance, McDonald and Smith (2009) found that contaminant stratification in a wellbore is not necessarily representative of stratification in the aquifer, and they discouraged using passive or micropurge sampling techniques.

Hutchins and Acree (2000) found considerable ambient flow in monitoring wells using an electromagnetic flowmeter. Izbicki and others (2005) studied temporal changes of chloride concentrations and vertical flow in observation wells under pumping conditions in California. The combination of flowmeter data and depth-dependent water-quality data revealed sources of saline water being transported from deeper parts of the aquifer into shallower parts. Similar observations showed a monitor well forming a connection between the higher and lower hydraulic head zones (Elci and others, 2001; Elci and others, 2003). Konikow and Hornberger (2006) modeled preferential groundwater flow through monitor wells and concluded that solutes can be redistributed in different aquifers through monitor wells. Zinn and Konikow (2007) used a numerical model to demonstrate that borehole flow can substantially bias groundwater ages determined from water samples, but they also indicated that the effects are highly dependent on local or regional flow conditions and may change with time.

Hanson and others (2002) attributed temporal differences in electromagnetic induction logs to possible seasonal seawater intrusion in Monterey, California. Newhouse and Hanson (2002) used a prototype borehole acoustic-doppler velocimeter for threedimensional flow measurements in uncased wells in Idaho. Their data delineated two independent flow zones with a downward flow component and indicated a more complex hydrogeologic setting than could be interpreted from water-table maps. Hanson (2005) noted that wellbores connect layered aquifers and that vertical borehole flow is mainly responsible for the extraction of water from or recharge of water to deeper aquifers.

The location of the freshwater-saltwater interface is strongly related to the ocean tide in Jeju Island, Korea (Kim and others, 2006). Salinity profiles changed depending on the stage of the tide. A sharp interface was observed during low tide, but the transition zone broadened to $60 \mathrm{ft}$ at high tide (Kim and others, 2008; Kim and others, 2009). The change was not directly attributed to borehole flow, although the shape of the specific-conductance profiles may indicate vertical flow in the monitor wells. Salinity profiles in long-screened coastal wells in Israel also varied with ocean tides, which was attributed to vertical flow in the borehole (Shalev and others, 2009). Numerical modeling that incorporated an open borehole indicated that vertical flow in the monitor well is three orders of magnitude greater than in the aquifer, which indicated that measured salinity profiles do not accurately reflect the freshwater-saltwater transition zone in the aquifer (Shalev and others, 2009).

\section{Acknowledgments}

Glenn Oyama and Darrell Wong of the Honolulu Board of Water Supply and Diane England of the State Commission on Water Resource Management provided access to numerous specific-conductance and temperature profiles, geophysical $\operatorname{logs}$, and other data. Paul Eyre, formerly of the U.S. Navy Public Works Center, and Joe Mendonca of the Maui Department of Water Supply provided information on pumping rates. Constructive comments from Delwyn Oki, William Souza, Randall Hanson, and many others from the USGS Pacific Islands Water Science Center helped improve the report.

\section{Physical Setting}

\section{Geography and Geology}

The Islands of Hawai'i include six major populated islands that were formed by eruption of thousands of lava flows as the Pacific Plate of the Earth's lithosphere moved over the Hawaiian hotspot. Each island consists of one or more shield volcanoes, from which extrusion of primarily thin basaltic lava flows from central calderas and from fissures along rift zones took place between 5 million years ago (Kaua'i) and the present (Hawai' $i$ ). The young basalts are highly permeable and form productive aquifers. Changes in sea level, subsidence, and erosion of volcanic rocks contributed to deposition of marine and terrestrial sediments on coastal plains and deeply incised valley floors (Peterson, 1993).

The aquifers in Hawai' $i$ are recharged by rainfall, the distribution of which is characterized by steep spatial gradients (Giambelluca and others, 1984). Maximum precipitation occurs at high altitudes and along the mountain flanks that are exposed to the northeast trade winds. Annual rainfall is less than $10 \mathrm{in}$. in dry leeward areas and can exceed 400 in. in wet mountainous areas (Giambelluca and others, 1986). Intense rainfall and steep terrain commonly produce flashy stream discharge, although most moderate storms generate little runoff and large amounts of infiltration because of the high permeability of the volcanic rocks (Peterson, 1972).

The most densely populated areas, and thus the most developed aquifers, in Hawai' $i$ are in the Honolulu-Pearl 
Harbor area on O'ahu (Oki, 2005) and in the Wailuku-'Tao area in central Maui (Meyer and Presley, 2001; Gingerich, 2008). Many areas in Hawai 'i are undergoing a transition in land use from decades of large-scale agriculture (sugarcane and pineapple) to small-scale diversified agriculture and rapidly expanding urban developments. Changes in recharge through different irrigation patterns and increasing water demands of a growing population affect the sustainability of the groundwater resources (Engott and Vana, 2007). In addition, it is unclear how changes in recharge associated with climate change will affect the groundwater resources.

\section{Hydrogeology}

More than 80 percent of Hawai'i's DMWs are located on O'ahu, and more than three-quarters of those are concentrated in the Honolulu-Pearl Harbor area (fig. 1). The regional hydrogeology of southern $\mathrm{O}^{\prime}$ ahu is therefore briefly summarized here, although many more detailed descriptions exist (for example, Stearns and Vaksvik, 1935; Wentworth, 1951; Visher and Mink, 1964; Hunt, 1996; Nichols and others, 1996). For a comprehensive overview of Maui's geology, the reader is referred to Stearns and Macdonald (1942).

\section{Flank Lavas}

O'ahu is formed by the eroded remnants of two shield volcanoes. Rocks from the older Wai'anae Volcano were dated between 3.7 and 2.9 Ma (Doell and Dalrymple, 1973; Presley and others, 1997). The volcanic rocks of the Wai 'anae Volcano consist primarily of thin-bedded shield-stage tholeitic flows that are on average $40 \mathrm{ft}$ thick and dip about 6 degrees (Stearns and Vaksvik, 1935). The lava flows of the shield-stage Lualualei Member of the Wai'anae Volcanics are 5-75 ft thick, those from the transitional or late shield-stage Kamaile 'unu Member are 10-120 ft thick, and those from the postshield-stage Pālehua Member are 50-100 ft thick (Stearns, 1940). Rocks from the Ko'olau Volcano consist mainly of thin-bedded shieldstage tholeitic flows that have ages between 2.6 and $1.8 \mathrm{Ma}$ (Doell and Dalrymple, 1973; Langenheim and Clague, 1987). The lava flows of the Ko'olau Volcano range in thickness from several to $80 \mathrm{ft}$, with an average thickness of $10 \mathrm{ft}$, and have dip angles between 3 and 10 degrees. In central $\mathrm{O}^{`} \mathrm{ahu}$, where lava flows of the Ko'olau Volcano overlap those of the Wai'anae Volcano, dips of the Ko'olau Basalt are typically between 3 and 5 degrees (Stearns and Vaksvik, 1935).

Openings within lava flows and at contacts between flows contribute to the high permeability of the volcanic rocks. The bulk hydraulic conductivity of the aquifer formed by flank lava flows is controlled by factors including the thickness of the flows, the thickness of clinker zones associated with ' $a$ ' $\bar{a}$ flows, extent of fractures, occurrence of lava tubes associated with pāhoehoe flows, and the degree of weathering (Lau and Mink, 2006). The effective regional horizontal hydraulic conductivity of dike-free flank lavas is on the order of 1,000 $\mathrm{ft} / \mathrm{d}$, although locally the horizontal hydraulic conductivity can vary by orders of magnitude (Hunt, 1996; Rotzoll, 2007). The basaltic aquifers are heterogeneous and anisotropic, with a horizontal hydraulic conductivity that tends to be greater parallel to the flow direction of lava flows than perpendicular to it (Nichols and others, 1996). The horizontal hydraulic conductivity can be as much as 200 times greater than the vertical hydraulic conductivity (Souza and Voss, 1987).

\section{Dike Zones}

The Wai'anae and Ko'olau Volcanoes each have two primary rift zones and a third less pronounced rift zone. The rift zones are characterized by numerous nearly vertical intrusive dikes (Stearns and Vaksvik, 1935). Dikes are thin, nearvertical sheets of massive, low-permeability rock that formed by magma intruding existing rocks and cooling beneath the surface. The abundance of dikes can be as high as 1,000 per mile in the center of the rift zone and decreases away from the center. Dikes impede lateral groundwater flow because of their low permeability (Takasaki and Mink, 1985). The overall hydraulic conductivity of an entire dike complex can be as low as $0.01 \mathrm{ft} / \mathrm{d}$, although the hydraulic conductivity of individual dikes may be lower and the conductivity of rocks between dikes may be much higher (Meyer and Souza, 1995).

\section{Sedimentary Deposits}

The coastal plain of southern $\mathrm{O}^{\text {‘ahu comprises terrestrial }}$ and marine sediments and reef limestone deposits. The coastal sedimentary wedge overlying the flank lavas commonly is referred to as caprock in literature on Hawaiian hydrology. In the area of Pearl Harbor, the caprock ranges in thickness from 1,000 ft near the coast to $0 \mathrm{ft}$ about 5 miles inland (see fig. 5). The hydraulic conductivity of individual units in the caprock spans several orders of magnitude, from 0.01 to $1 \mathrm{ft} / \mathrm{d}$ for fine-grained muds and saprolite (Wentworth, 1938) to as much as several thousand feet per day for coral gravels and reef limestone deposits (Oki, 1998). The overall permeability of caprock is lower than that of the underlying basalt. The caprock, therefore, impedes groundwater discharge to the ocean and acts as a confining unit over the volcanic-rock aquifer (Visher and Mink, 1964). As a result, the groundwater levels in the Pearl Harbor-Honolulu area are higher than in comparable areas without caprock.

Alluvium-filled stream valleys also affect groundwater flow. During sea-level lowstands, stream valleys were deeply incised and subsequently filled with terrestrial and marine sediments. Additionally, beneath the valley-filling sedimentary deposits is a layer of highly weathered volcanic rock. The valley fills and underlying weathered rock have lower permeability than the surrounding flank lavas and can impede lateral groundwater flow across valleys. The effectiveness of the barriers formed by the valley-fill deposits is dependent on the hydraulic properties of the deposits and depth of valley 
incision (Oki, 2005; Rotzoll and El-Kadi, 2007). Contrasting water levels on either side of a hydrologic barrier are an indication of the barrier's effectiveness at impeding horizontal groundwater flow. Valley fills, dike zones, and the coastal caprock compartmentalize aquifers in southern $\mathrm{O}^{\prime} \mathrm{ahu}$, and these barriers tend to enhance water-level drawdown caused by groundwater withdrawals from pumped wells.

\section{Groundwater Dynamics in the Freshwater Lens}

Groundwater in Hawai 'i principally occurs in the flank lavas as a freshwater lens that floats on saltwater and as highlevel water in dike-impounded systems in the rift zones of the volcanoes (Mink and Lau, 1990). The latter form of occurrence will not be discussed in detail, because most DMWs are located within freshwater-lens systems. Furthermore, the distribution of freshwater and saltwater at depth in the dikeimpounded systems remains uncertain because the principles of hydrostatic buoyancy may not strictly apply in the rift zones (Hunt, 1996). Besides freshwater-lens and dike-impounded groundwater systems, groundwater exists on $\mathrm{O}^{\prime}$ ahu as highlevel water (about $275 \mathrm{ft}$ above sea level) beneath the Schofield Plateau between hydrologic barriers of uncertain origin (fig. 1) and locally as perched water bodies over poorly permeable layers (for example, volcanic ash).

The freshwater lens is commonly called a Ghyben-Herzberg lens following the independent descriptions of Badon Ghyben (1889) and Herzberg (1901). The occurrence of the freshwater lens in Hawai' $i$ was described in the early part of the 20th century by a number of individuals, including Lindgren (1903), Andrews (1909), Palmer (1927), and Meinzer (1930). Understanding the factors that control the occurrence and dynamics of a freshwater lens was later improved by Stearns and Vaksvik (1935), Stearns and Macdonald (1942), Wentworth (1942, 1947, 1948, 1951), Cox (1954), Visher and Mink (1964), Lau (1964, 1967), and Chung and others (1982). According to the Ghyben-Herzberg principle, which assumes hydrostatic conditions, the altitude of the water table in a freshwater lens is controlled by the isostatic buoyancy of the freshwater floating on saltwater. For freshwater and saltwater densities of 1,000 and $1,025 \mathrm{~kg} / \mathrm{m}^{3}$, respectively, the GhybenHerzberg principle is simplified to the following relation:

$$
z=-40 h,
$$

where $z$ is the depth of the interface between freshwater and saltwater in feet below sea level and $h$ is the water level in feet above sea level. For every foot of freshwater above mean sea level the freshwater lens extends $40 \mathrm{ft}$ below sea level, a relation that has been widely used in Hawai ' $i$ (Izuka and Gingerich, 1998; Oki and Meyer, 2001; Rotzoll and others, 2010) and that will be used in this report. The Ghyben-Herzberg principle generally is applicable in homogeneous steady-state flow systems in which the transition between freshwater and saltwater is sharp (Hubbert, 1940; Glover, 1959). Mixing of freshwater and saltwater forms a brackish-water transition zone separating the two water bodies. The thickness of the brackish-water transition zone may be enhanced by factors including ocean tides and variations in barometric pressure, recharge, and discharge (Wentworth, 1948; Cooper, 1959).

The freshwater-lens system in southern $\mathrm{O}^{\prime}$ ahu comprises an upper layer of water derived from local rainfall and irrigation over the past decades, a cooler freshwater core containing waters with measured carbon-14 ages of about 1,800 years, the brackish-water transition zone, and saltwater with measured carbon-14 ages ranging from about 9,000 to 6,000 years (Voss and Wood, 1994). The thickness of the freshwater lens depends on factors including the amount of recharge, the hydraulic properties of the aquifer, and the effectiveness of the sedimentary caprock that acts as a coastal confining unit. Generally, brackish groundwater occurs in areas of low recharge without caprock sediments (Stearns, 1941), such as the west side of the Island of Hawai 'i or central Maui. Thin freshwater lenses (tens of feet) exist in areas where the coastal caprock is thin, such as the Kawailoa area of northern $\mathrm{O}$ 'ahu. Thick freshwater lenses (hundreds of feet) exist in the Honolulu and Pearl Harbor areas of O'ahu and the 'Tao area of Maui, where coastal caprock effectively confines the volcanic-rock aquifer (Meyer and Presley, 2001). Water-table altitudes are typically lowest at the coast and increase inland at a rate of about $1 \mathrm{ft} / \mathrm{mi}$ (Lau and Mink, 2006). However, local variations in the hydraulic gradient may be caused by aquifer heterogeneities, discharging springs, heavily pumped wells, and valley-fill or other barriers (Oki, 2005).

The amount of fresh groundwater stored in a freshwater lens may change over time in response to changes in recharge or discharge. Early measurements from about 1880 indicate predevelopment water levels between 32 and $42 \mathrm{ft}$ above sea level in the Pearl Harbor and Honolulu areas. In 2000, the regional water table in the Pearl Harbor and Honolulu areas was between 18 and $25 \mathrm{ft}$ above sea level. Relatively wet years during 2002-06 resulted in recharge that caused water levels to rise by several feet.

Groundwater flow within the freshwater lens of island aquifers is mainly horizontal, although groundwater flow has a downward component in inland recharge areas and an upward component in coastal discharge areas (Tóth, 1962). The regional groundwater flow pattern in volcanic-rock aquifers can be summarized as follows (after Souza and Voss, 1987; Oki, 1998): (1) most of the recharge of fresh groundwater from rainfall occurs in the mountainous interior areas, and groundwater flow has a downward component in the inland recharge areas; (2) groundwater flow is from inland recharge areas towards coastal discharge areas and is generally horizontal; (3) in the coastal area, a caprock impedes groundwater discharge to the ocean, and the flow of fresh and brackish water generally is upward into the caprock; and (4) the caprock also impedes the inflow of saltwater into the volcanic-rock aquifer (fig. 2).

Evidence for upward flow near the discharge area of the flow system is available from the Halekauwila Well located $660 \mathrm{ft}$ 


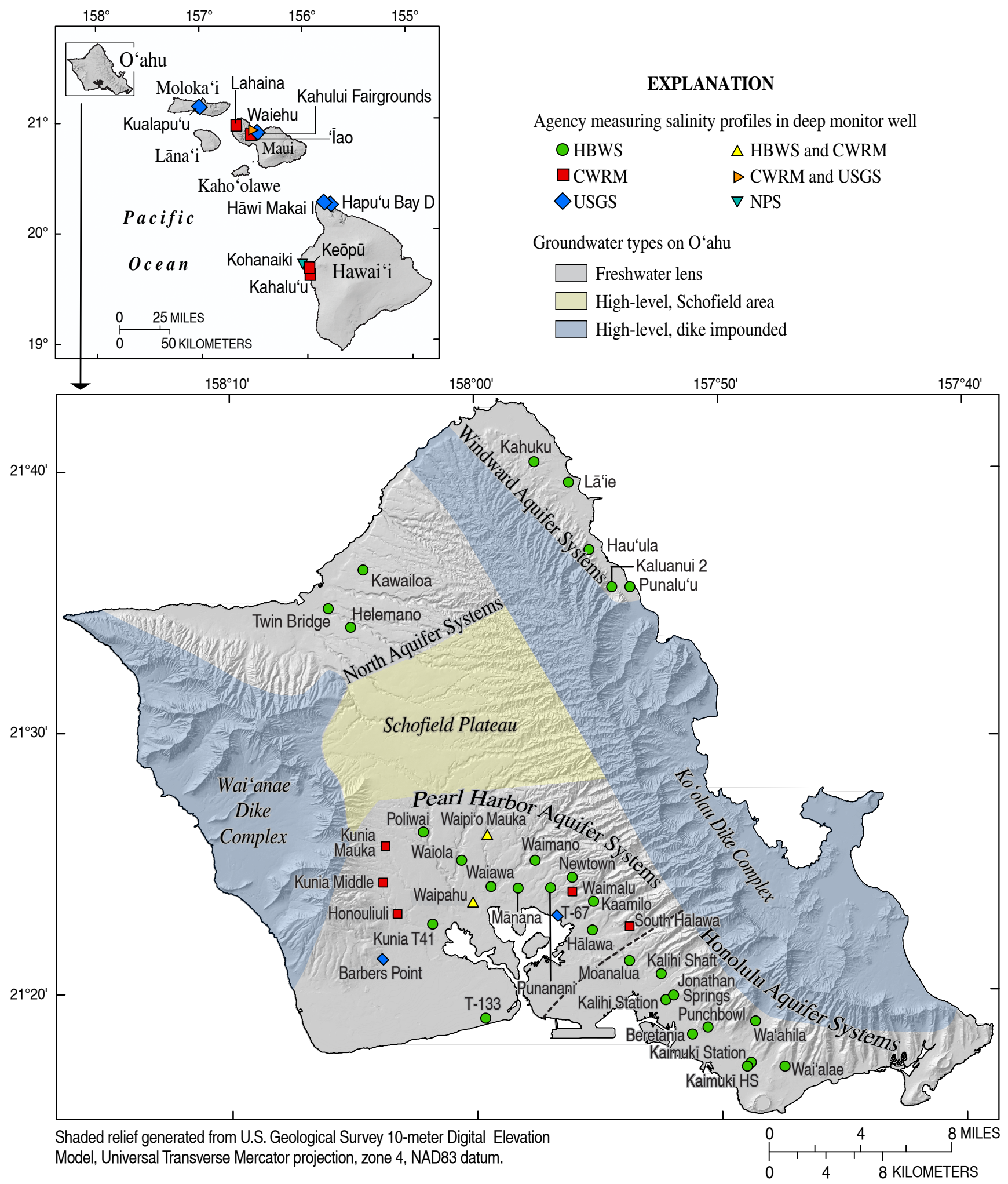

Figure 1. Location of deep monitor wells that penetrate through the transition zone between freshwater and saltwater in Hawai'i, and areas with freshwater-lens systems and high-level groundwater on O'ahu, Hawaii (modified from Mink and Lau, 1990). Symbols indicate the agency that collected most of the salinity profiles from the indicated well: Honolulu Board of Water Supply (HBWS), Commission on Water Resource Management (CWRM), U.S. Geological Survey (USGS), and National Park Service (NPS). The dashed line separates the Pearl Harbor aquifer systems from the Honolulu aquifer systems. 
inland near the coastal discharge zone of the Honolulu area (fig. 3). This artesian well has two piezometers open to the Ko'olau Basalt aquifer at altitudes of -988 and -1,043 ft. Generally, the equivalent freshwater head (elevation of freshwater in the well needed to balance the pressure outside of the well screen created by the denser brackish water and saltwater) in the deeper piezometer is about $1.5 \mathrm{ft}$ higher than in the shallower piezometer, indicating an upward vertical head gradient of $0.027 \mathrm{ft} / \mathrm{ft}$ (140 ft/mi). Upward flow in the aquifer is consistent with the regional aquifer flow concept at this location. Upward flow also occurs near the Helemano area of northern O'ahu. Two exploratory wells located 4,820 ft inland and $20 \mathrm{ft}$ apart (fig. 3) are open to the Ko'olau Basalt aquifer, one from altitudes of -68.5 to $-73.5 \mathrm{ft}$ and the other from -271 to $-291 \mathrm{ft}$. During 1995, artesian heads measured in the deep well were $0.23 \mathrm{ft}$ higher than in the shallow well (Presley and Oki, 1996). The smaller vertical head gradient of $0.001 \mathrm{ft} / \mathrm{ft}(5 \mathrm{ft} /$ mi) associated with the Helemano wells compared to the head gradient of $0.027 \mathrm{ft} / \mathrm{ft}$ from the Halekauwila Well may be related to the greater distance to the discharge zone associated with the Helemano wells.

\section{General Characteristics of Salinity Profiles and Deep Monitor Wells}

Deep monitor wells in Hawai' $i$ generally penetrate through the freshwater lens and the transition zone into saltwater, although some wells terminate in the brackish-water transition zone. Because the amount of water that can be developed for potable use from a freshwater lens is constrained by its salinity, the altitudes of the top and midpoint of the transition zone are monitored in Hawai ' $i$ (table 1). A change in thickness of the upper part of the transition zone can be identified by monitoring the water level and the top and midpoint of

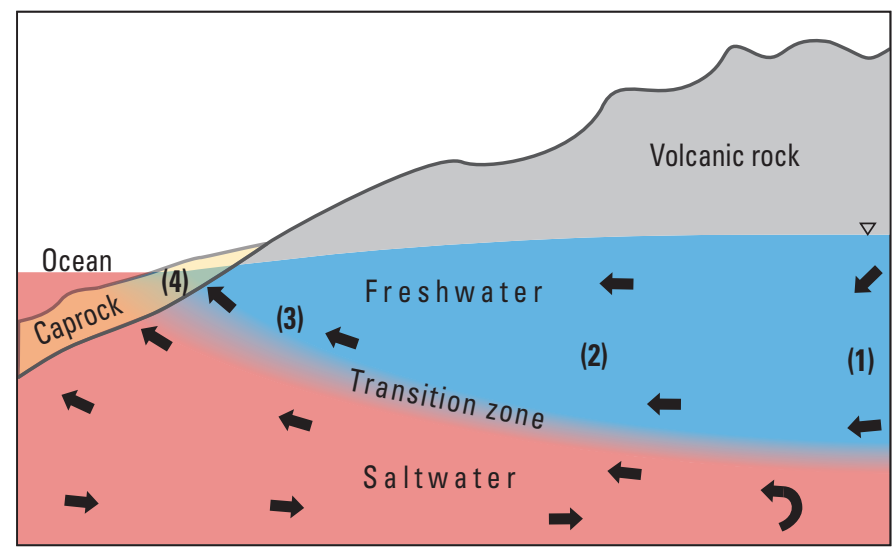

Figure 2. Generalized diagram of the groundwater flow pattern in a freshwater-lens system in volcanic rocks in Hawai'i: (1) downward flow in recharge areas, (2) horizontal flow, (3) upward flow in coastal discharge areas, and (4) discharge through the coastal sediments. the transition zone over time. By convention, the depth of the midpoint between freshwater and saltwater is the depth where the fluid specific conductance equals 25,000 microsiemens per centimeter $(\mu \mathrm{S} / \mathrm{cm})$. However, this may not represent the true 50-percent point of seawater salinity, because the measured specific conductance at the bottom of several DMWs exceeds 50,000 $\mu \mathrm{S} / \mathrm{cm}$. For example, the maximum specific conductance in South Hālawa DMW and Waiehu DMW is $51,500 \mu \mathrm{S} / \mathrm{cm}$, and the maximum specific conductance in Punalu' $u$ DMW is $54,250 \mu \mathrm{S} / \mathrm{cm}$. For the purposes of this report, saltwater is defined as having a specific conductance of $55,000 \mu \mathrm{S} / \mathrm{cm}$, although the definition of the midpoint is kept at the conventional specific conductance of $25,000 \mu \mathrm{S} / \mathrm{cm}$. The top of the transition zone is represented by a salinity of about 2 percent of the seawater salinity, corresponding to a specific conductance of $1,000 \mu \mathrm{S} / \mathrm{cm}$, which is approximately equivalent to the advisory secondary drinking water standard of 250 milligrams per liter $(\mathrm{mg} / \mathrm{L})$ for chloride, based on aesthetic concerns (U.S. Environmental Protection Agency, 2006).

\section{Sources of Available Data}

\section{Historical}

Information from DMWs in Hawai'i has contributed tremendously to the understanding of water quality in freshwater-lens systems. Palmer (1927) reported a progressive increase in salinity with depth in several wells below $-500 \mathrm{ft}$, indicating a broad transition zone. The first salinity measurements with depth on Maui were made in 1935 (Stearns and Macdonald, 1942, p. 117). Chloride concentrations of water samples collected at selected depths in a well increased from 500 to $18,000 \mathrm{mg} / \mathrm{L}$ between -116 and $-139 \mathrm{ft}$ relative to mean sea level (fig. 4). The observed water table was at $3.24 \mathrm{ft}$ above sea level, and the midpoint of the salinity profile was at $-124.2 \mathrm{ft}$. Using the Ghyben-Herzberg ratio of 1:40, the estimated midpoint is at $-129.6 \mathrm{ft}$, which is consistent with the observed midpoint depth from the salinity profile.

Table 1. Salinity of the top and midpoint of the freshwatersaltwater transition zone compared to saltwater salinity.

$[\mu \mathrm{S} / \mathrm{cm}$, microsiemens per centimeter; $\mathrm{mg} / \mathrm{L}$, milligram per liter; ppm, parts per million; \%, percent; , approximately]

\begin{tabular}{lcccc}
\hline \multicolumn{1}{c}{$\begin{array}{c}\text { Physical } \\
\text { property }\end{array}$} & Units & $\begin{array}{c}\text { Top of the } \\
\text { transition } \\
\text { zone }\end{array}$ & $\begin{array}{c}\text { Midpoint of } \\
\text { the transi- } \\
\text { tion zone }\end{array}$ & Saltwater \\
\hline $\begin{array}{l}\text { Specific } \\
\text { conductance }\end{array}$ & $\mu \mathrm{S} / \mathrm{cm}$ & 1,000 & 25,000 & 55,000 \\
$\begin{array}{l}\text { Chloride } \\
\text { Salinity }\end{array}$ & $\mathrm{mg} / \mathrm{L}$ & 250 & 9,800 & 19,600 \\
$\begin{array}{l}\text { Seawater } \\
\text { salinity }\end{array}$ & $\%$ & 0.7 & 17.9 & 35.7 \\
\hline
\end{tabular}


In the 1950s, several specific-conductance logs were collected by the Hawaiian Sugar Planters' Association using a bridge and weighted cell to measure capacitance variability between the two elements (Lao and others, 1969). In 1960, wells at Kaimukī and Beretania pumping stations were drilled $1,500 \mathrm{ft}$ deep into the basalt aquifer (Lao, 2005). Visher and Mink (1964) observed a thick transition (1,200 ft) between freshwater and saltwater in well T-67, which is located near the Pearl Harbor shoreline (fig. 1). Well T-133 (fig. 1) was drilled in 1965 near O'ahu's south coast to a depth of $-1,070$ $\mathrm{ft}$ relative to mean sea level. The well penetrates the transition zone into the saltwater (Cox and Lao, 1967). These early wells were used to make preliminary observations of the freshwaterlens thickness. Over time, additional monitor wells were drilled, and salinity profiles in these wells were measured on a routine basis. Starting in 1966, the applicability of electrical geophysical logging (Lao and others, 1969; Peterson and Lao, 1970) and neutron logging techniques (Peterson and Seghal, 1974) were tested in several wells on O'ahu and Kaua'i by the HBWS and the University of Hawai' ${ }^{i}$. Beginning in 1968, as

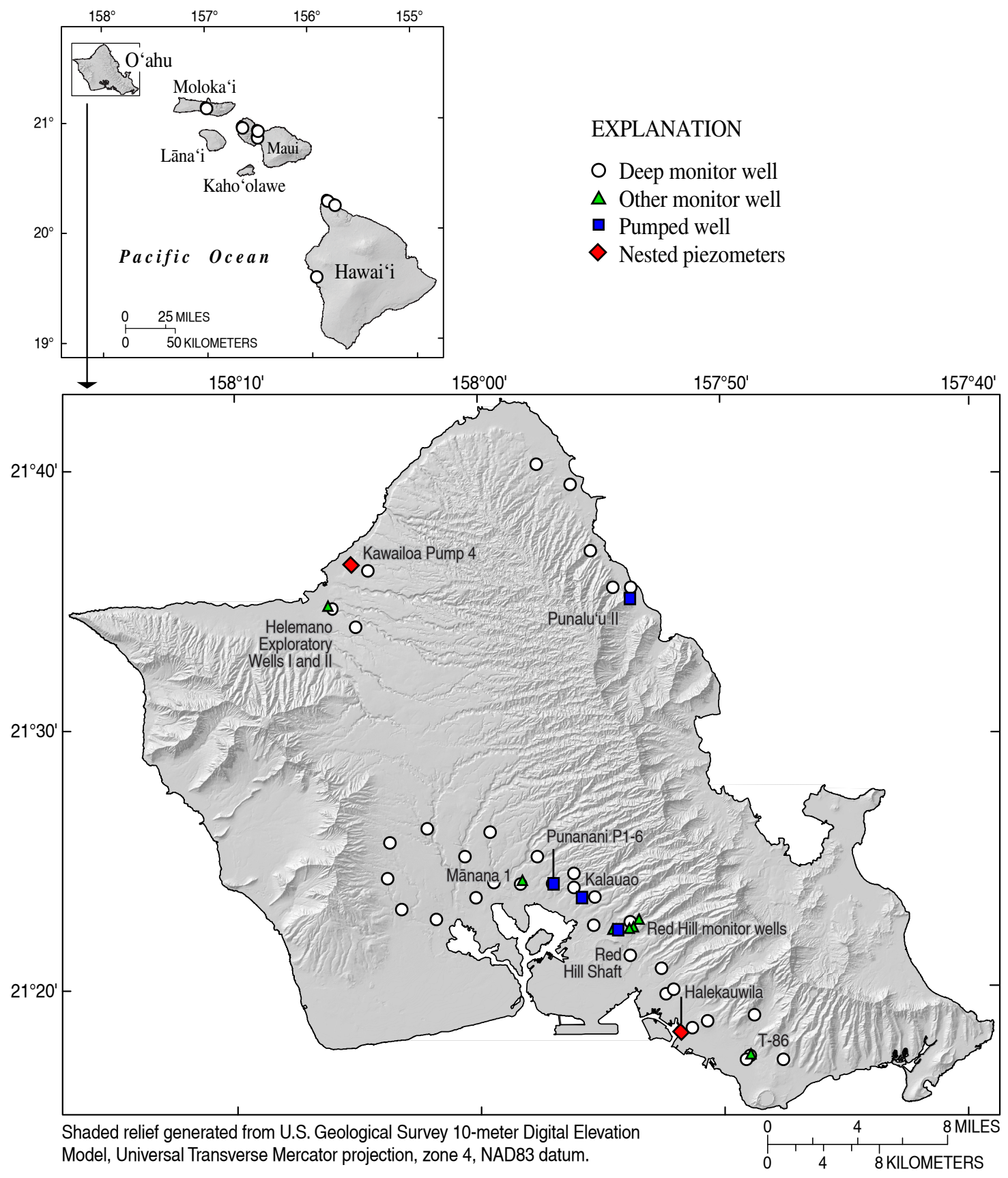

Figure 3. Locations and names of selected wells mentioned in the text, Island of O'ahu. 
part of the testing of techniques, the HBWS regularly logged four DMWs (T-86, Beretania DMW, Punanani DMW, and Punalu'u DMW) with analog specific-conductance and temperature sensors. In the 1980s, the logging efforts were expanded to include additional DMWs (Kaimukī Station DMW, Waipahu DMW, and Waipi 'o Mauka DMW on O'ahu and Waiehu DMW on Maui). Because the monitor well T-86 at Kaimukī pumping station was not plumb, which made monitoring at depth difficult, it was replaced with Kaimukī Station DMW in 1986.

\section{Recent}

In the past 10 years, additional DMWs have been drilled and are frequently logged to monitor the freshwater lens. For example, during 1999-2002, 19 DMWs were drilled. Currently, 40 DMWs regularly are logged in Hawai'i (fig. 5). Altogether, a dense network of monitor wells exists in the Pearl Harbor and Honolulu areas. Several agencies collect salinity profiles on a routine basis, and some DMWs are monitored by more than one agency. The majority of wells (30) are monitored by the HBWS, 11 are monitored by the CWRM, and 2 are monitored by the U.S. Geological Survey (USGS) (table 2). Recently (2008), a DMW (Kohanaiki DMW) was completed near the western coast on the Island of Hawai ' $i$, and this well is monitored by the National Park Service (NPS). The 797 salinity profiles analyzed for this study include profiles measured occasionally in Twin Bridge DMW, Hāwī Makai I DMW, Hapu'u Bay D DMW, and profiles from monitor wells that regularly are logged (fig. 5), excluding Kohanaiki DMW on the Island of Hawai'i.

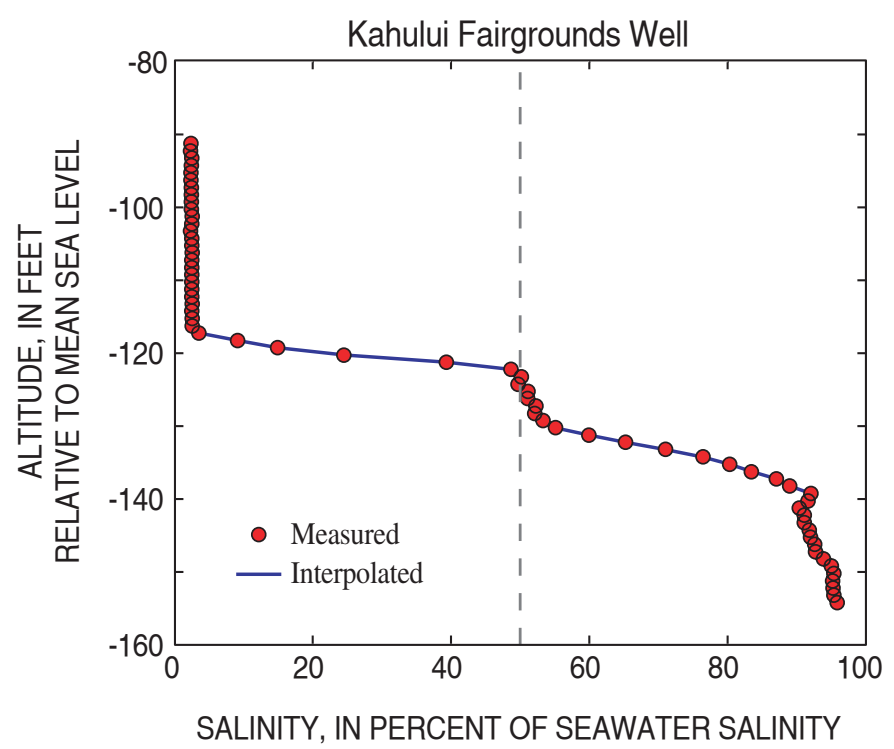

Figure 4. Salinity-depth profile of Kahului Fairgrounds Well, central Maui, Hawai'i. Water samples were taken at 1-foot intervals on May 22, 1936, and analyzed for salt content (Stearns and Macdonald, 1942).

\section{Data Collection Methods}

Salinity-profile data were collected using several methods. An early method involved collecting water samples at discrete depths and analyzing the water samples for salt content. This method is still used by the USGS at Waiehu DMW on Maui. Early profiles were collected by the HBWS with analog specific-conductance and temperature sensors and were recorded on paper charts at three different sensitivity scales. Data handling and archiving improved in 1998, when the CWRM began using a digital conductivity, temperature, and depth sensor (CTD) to collect data. The HBWS began collecting data with this type of sensor in 1999. The HBWS uses a winch equipped with a rotation-counting wheel for automatic measurements at every $0.33 \mathrm{ft}$. The CWRM and USGS use recorded pressure data and convert pressure to depth. The USGS corrects for errors in pressure measurements using a calibrated steel cable to measure depths. The HBWS, the CWRM, and the USGS currently log the monitor wells 2-4 times per year, although some data gaps exist when equipment was malfunctioning or unavailable.

\section{Analysis of Available Data}

Proper comparison of data from different sources requires consideration of differences in how instruments record fluid conductivity. The analog recorder of the HBWS compensated for temperature internally and recorded specific conductance at a reference temperature of $25^{\circ} \mathrm{C}$. Selected profiles collected by the HBWS with the analog recorder were digitized from the paper charts for this analysis. The electrical conductivity measured by the HBWS with a digital sensor since 1999, and all electrical-conductivity profiles collected by the CWRM and USGS, required conversion from electrical conductivity under ambient temperatures to specific conductance at $25^{\circ} \mathrm{C}$. The following equation was used for postprocessing (Clesceri and others, 1998; Hayashi, 2004):

$$
S C=\frac{E C}{1+0.0191(t-25)}
$$

where $S C$ is the specific conductance, in microsiemens per centimeter at $25^{\circ} \mathrm{C}, E C$ is the measured electrical conductivity, in microsiemens per centimeter, and $t$ is the measured temperature, in degrees Celsius.

The USGS integrates regular accuracy checks of the conductivity sensor and annual accuracy checks of the temperature sensor in their data-collection routine. The USGS checks the accuracy of the conductivity sensor with four potassium chloride standard solutions $(1,10,25$, and $50 \mathrm{mS} / \mathrm{cm})$ before each use. Differences between specific conductance of each standard and the corresponding measured specific conductance are recorded and archived for quality control. The sensor is considered properly calibrated if the error is within 5 percent 
(U.S. Geological Survey, variously dated). The accuracy of the pressure sensor of the instrument is checked during each log by comparing the recorded pressure to known depths from the calibrated steel cable.
The CWRM did not check the accuracy of their conductivity sensor before each deployment, although the sensor was sent back to the manufacturer annually for calibration. Between March 2007 and August 2008, negative conductivity

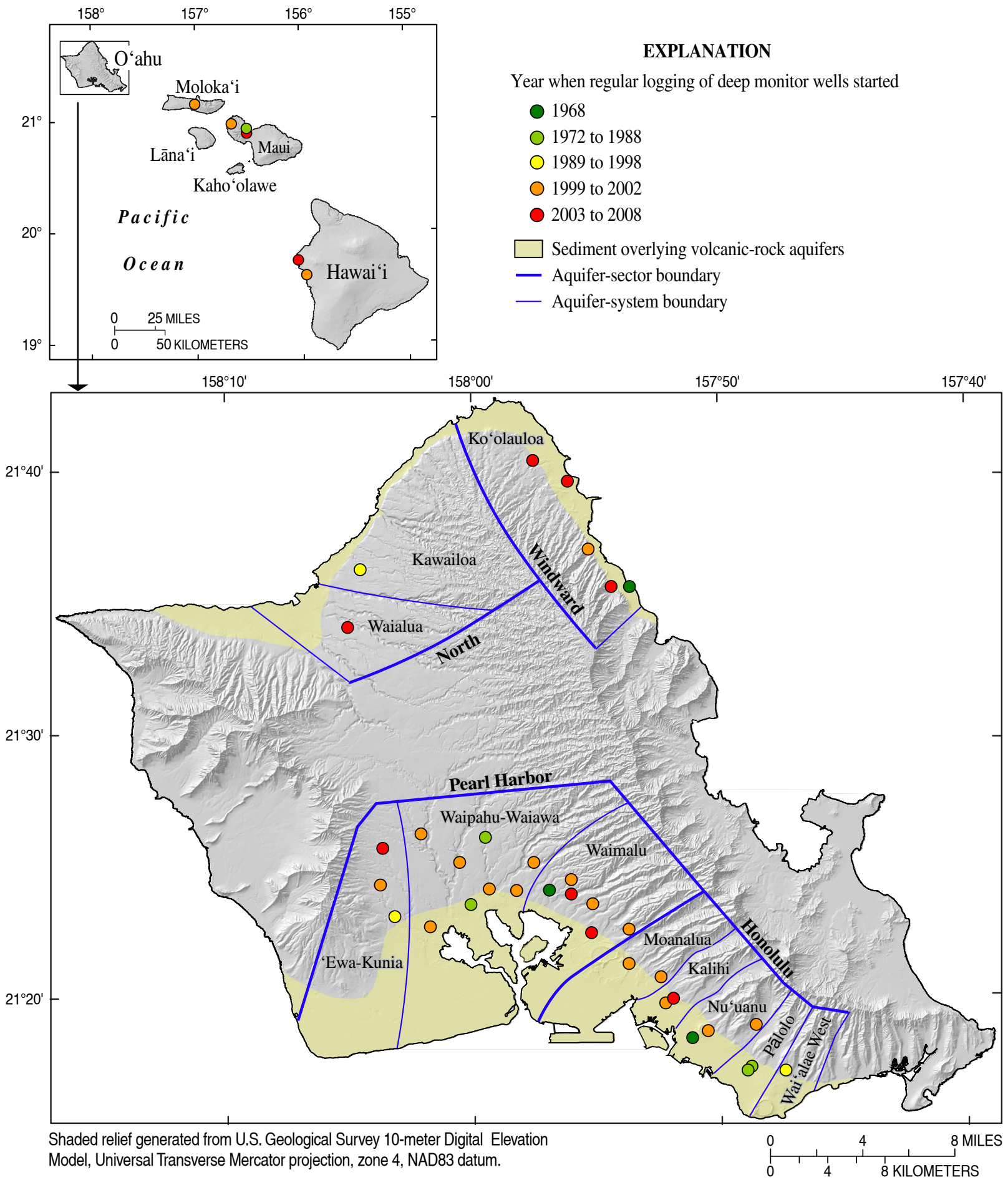

Figure 5. Deep monitor wells in Hawai'i, with the time period when routine logging of salinity profiles in each began. Also shown are the State of Hawai'i aquifer systems and sectors for the freshwater-lens systems on O'ahu (modified from Mink and Lau, 1990) and the surficial extension of capping sediments on O'ahu. 
values were measured in the shallow part of profiles using the CWRM sensor. On March 27, 2008, the USGS and CWRM checked the accuracy of the CWRM sensor using standard solutions and found the following errors: -137 percent at $1 \mathrm{mS} / \mathrm{cm}$; -15.4 percent at $10 \mathrm{mS} / \mathrm{cm} ;-7$ percent at $25 \mathrm{mS} / \mathrm{cm}$; and -4.5 percent at $50 \mathrm{mS} / \mathrm{cm}$. Because of uncertainty related to the accuracy of the CWRM sensor, all profiles collected using the CWRM sensor between March 2007 and August 2008 were excluded from the analysis. The CWRM acquired a new sensor in June 2008. The HBWS also did not check the calibration of the conductivity sensor before each use, although they sent their digital sensor back at least once to the manufacturer for calibration in June 2008.

To enable meaningful comparisons of salinity profiles collected by different agencies and instruments, consistent quality-assurance (protocol) and quality-control (independent check) measures are needed. Regular accuracy checks of the conductivity, temperature, and pressure sensors are necessary to ensure proper data quality. In addition, review procedures conducted by personnel not directly involved in the data collection are part of a sound approach to data collection.

\section{Well-Construction Information}

The monitor wells used in this study generally penetrate through the transition zone into saltwater and have bottom altitudes ranging from -137 to $-1,881 \mathrm{ft}$ relative to mean sea level. The shallower wells are located on the Island of Hawai' $i$, whereas the deepest wells are in the Pearl Harbor and Honolulu areas of $\mathrm{O}^{\prime} \mathrm{ahu}$. The wells generally are cased above the water table and are uncased at depths below several tens to a few hundreds of feet below mean sea level (table 2). The Honouliuli DMW, Twin Bridge DMW, Kawailoa DMW, Kualapu 'u DMW, and Kahalu 'u DMW are cased to bottom depth with slotted casing. Casing diameters range from 4 to 14 in. The uncased holes have uneven diameters, because the volcanic rocks penetrated have varying degrees of competence and voids. Caliper logs indicate that it is not uncommon for the hole diameter to vary between 10 and 20 in. over a vertical distance of several feet (see fig. 9).

\section{Borehole Flow}

\section{Indicators of Vertical Borehole Flow}

Data from salinity profiles generally have been used under the assumption that the observed vertical distribution of salinity in the borehole is representative of the salinity in the surrounding aquifer. However, natural or anthropogenically induced vertical hydraulic gradients in the aquifer can generate vertical flow that is greater in the borehole than in the aquifer, causing salinity inside the well to be displaced with respect to the aquifer (Oki and Presley, 2008). Indicators of vertical borehole flow include steplike changes in specific conductance or temperature with depth, flow measurements in monitor wells, and differences in observed salinities in paired shallow and deep wells.

\section{Steplike Change of Salinity with Depth}

\section{Concept}

Vertical borehole flow commonly is evident in measured salinity profiles as steplike changes in specific conductance with depth. These steps indicate where water may be either entering or exiting the borehole (Eyre, 1987). Flow may be upward, downward, converging, or diverging (fig. 6) (Oki and Presley, 2008). Temperature profiles have been used to estimate groundwater flow rates (Stallman, 1963; Bredehoeft and Papadopulos, 1965; Cartwright, 1970; Sorey, 1971), and analysis of thermal anomalies allows a quantitative estimate of water flow within a borehole or between a borehole and intersecting fractures (Drury and Jessop, 1982; Drury, 1984). Steplike changes in available temperature profiles in Hawai ' $i$ commonly occur at the same depths as those observed in salinity profiles. However, the temperature distribution with depth in the aquifer, the temperature near the bottom of the DMW, and the exact geothermal gradient are unknown, which makes it difficult to interpret deviations in temperature profiles. The analyses in this study therefore focus on steps in salinity profiles, because the general shape of the profile and the specific conductance of saltwater are known.

Upward Flow.-Suppose water flows into a borehole at a depth where a conductive layer is present and flows upward within the borehole, driven by an upward vertical hydraulic gradient. As the water moves up within the borehole through a massive, low-permeability layer, little or no inflow or outflow occurs. Thus, the salinity of the water in this zone remains nearly uniform and equal to the salinity of the inflowing water. Water flows out of the borehole into a shallower conductive zone where the horizontal hydraulic gradient is directed away from the borehole. Water that exits the borehole mixes with water of lower salinity in the aquifer. The section over which upward flow occurs appears as a vertical line in the measured specific-conductance profile, and the horizontal line shallower in the profile is indicative of the outflow location. The deviation from the assumed aquifer salinity appears as an upwardflow step (fig. 6A).

Downward Flow.-Suppose water flows into a borehole at a depth where a conductive layer is present and downward within the borehole, driven by a downward vertical hydraulic gradient. As the water flows down in the borehole through a massive, low-permeability layer where no mixing with the water outside the borehole occurs, the salinity of the water in this zone remains nearly equal to the salinity of the inflowing water. Water flows out of the borehole into a deeper conductive zone where the horizontal hydraulic gradient is directed away from the borehole and mixes with water of higher salinity in the aquifer. The section over which downward flow occurs appears as a vertical line in the measured specific-conductance profile, 
Table 2. Characteristics of deep monitor wells and summary of available salinity and temperature profiles (as of March 2009) used in this study.

[HBWS, Honolulu Board of Water Supply; CWRM, Hawai ' i Commission on Water Resource Management; USGS, U.S. Geological Survey; C, Fluid electrical conductivity; T, Temperature; ft, feet relative to mean sea level; --, not applicable]

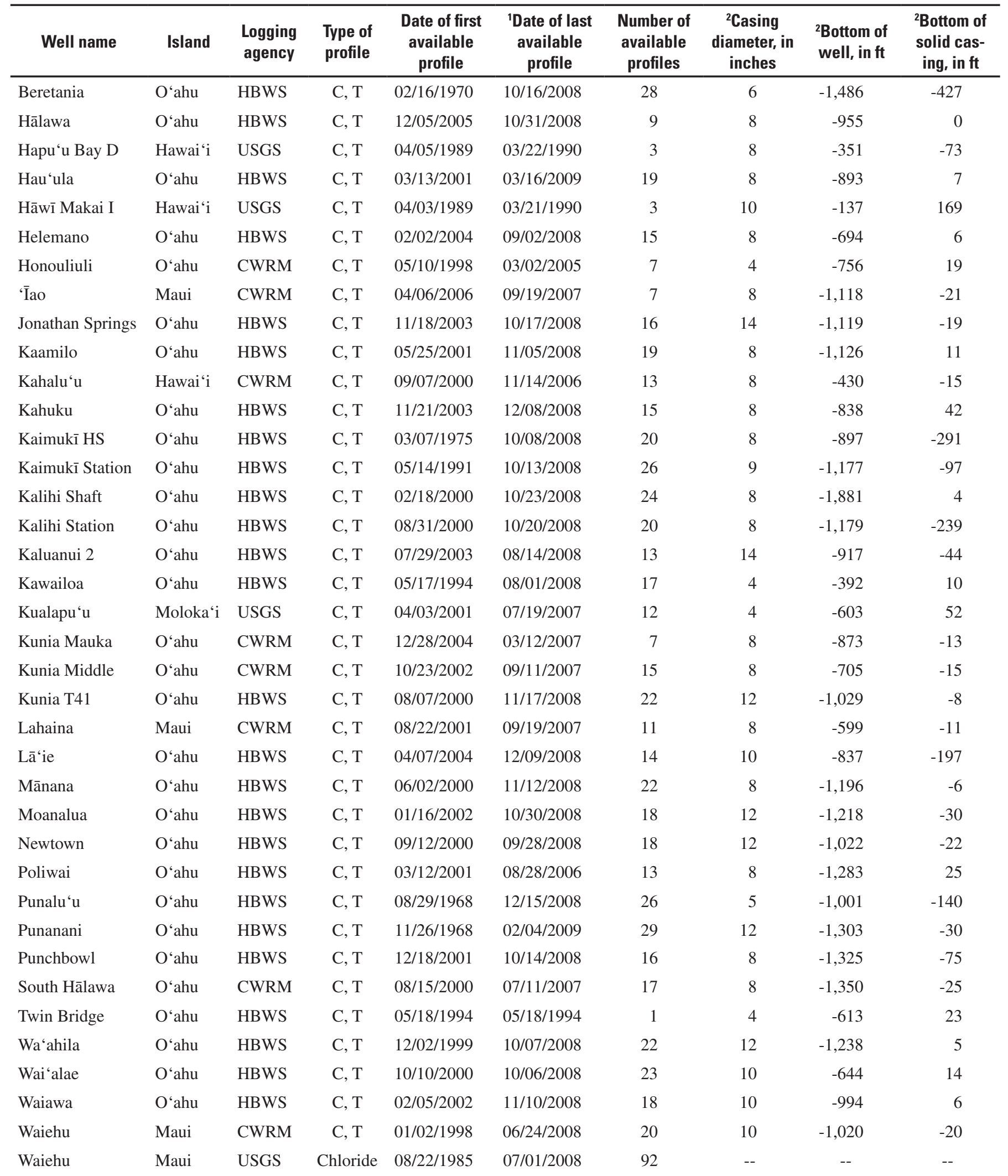


Table 2. Characteristics of deep monitor wells and summary of available salinity and temperature profiles (as of March 2009) used in this study. - Continued.

[HBWS, Honolulu Board of Water Supply; CWRM, Hawai 'i Commission on Water Resource Management; USGS, U.S. Geological Survey; C, Fluid electrical conductivity; T, Temperature; ft, feet relative to mean sea level; --, not applicable]

\begin{tabular}{lllllcccrc}
\hline Well name & Island & $\begin{array}{c}\text { Logging } \\
\text { agency }\end{array}$ & $\begin{array}{c}\text { Type of } \\
\text { profile }\end{array}$ & $\begin{array}{c}\text { Date of first } \\
\text { available } \\
\text { profile }\end{array}$ & $\begin{array}{c}\text { 'Date of last } \\
\text { available } \\
\text { profile }\end{array}$ & $\begin{array}{c}\text { Number of } \\
\text { available } \\
\text { profiles }\end{array}$ & $\begin{array}{c}{ }^{2} \text { Casing } \\
\text { diameter, in } \\
\text { inches }\end{array}$ & $\begin{array}{c}{ }^{2} \text { Bottom of } \\
\text { well, in ft }\end{array}$ & $\begin{array}{c}{ }^{2} \text { Bottom of } \\
\text { solid cas- } \\
\text { ing, in ft }\end{array}$ \\
\hline Waimalu & O'ahu & CWRM & C, T & $01 / 09 / 2005$ & $09 / 30 / 2008$ & 10 & 10 & -975 & -45 \\
Waimano & O'ahu & HBWS & C, T & $01 / 17 / 2002$ & $11 / 06 / 2008$ & 14 & 14 & $-1,032$ & 2 \\
Waiola & O'ahu & HBWS & C, T & $02 / 15 / 2000$ & $01 / 06 / 2004$ & 9 & 8 & -982 & 13 \\
Waipahu & O'ahu & HBWS & C, T & $11 / 13 / 1986$ & $11 / 13 / 2008$ & 20 & 12 & $-1,074$ & -12 \\
Waipahu & O'ahu & CWRM & C, T & $01 / 16 / 1998$ & $03 / 24 / 2009$ & 24 & -- & -- & -- \\
Waipi'o Mauka & O'ahu & HBWS & C, T & $04 / 23 / 1987$ & $05 / 27 / 2004$ & 9 & 9 & $-1,377$ & 0 \\
Waipi' ${ }^{\prime}$ Mauka & O'ahu & CWRM & C, T & $01 / 16 / 1998$ & $07 / 12 / 2007$ & 21 & -- & -- & -- \\
\hline
\end{tabular}

${ }^{1}$ Last available profile refers to at the time of this study.

${ }^{2}$ Information from CWRM.
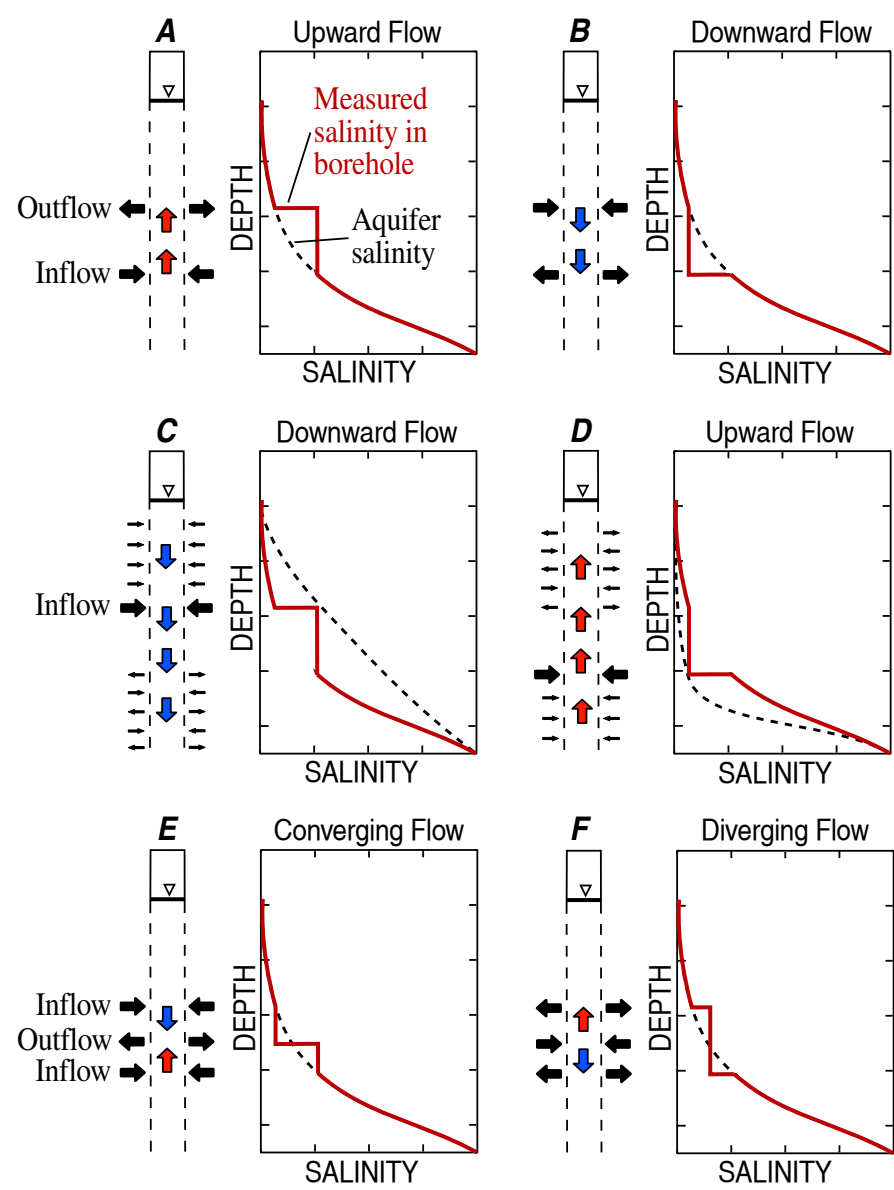

Figure 6. Diagrams of conceptual salinity profiles of different shapes in a borehole (modified from Oki and Presley, 2008). A, Upward flow. $B$, Downward flow. $C$, Downward flow. $D$, Upward flow. $E$, Converging flow. $F$, Diverging flow. and the horizontal line deeper in the profile is indicative of the outflow location. The deviation from the assumed aquifer salinity appears as a downward-flow step (fig. 6B).

Because aquifer salinity is unknown, it is not possible to determine unequivocally whether an upward or downward flow condition exists solely by inspection of a measured salinity profile. This is illustrated in the next cases (figs. $6 C$ and $6 D$ ), in which the same step can be reasonably interpreted to be indicative of flow in either direction. Diffuse inflow of water from the aquifer at a shallow depth interval with downward flow results in a measured salinity profile that is slightly curved above the zone of high inflow (fig. $6 \mathrm{C}$ ). The depth of higher inflow of water that is saltier than the water in the well is the horizontal line in the observed profile. The section over which the salinity remains constant can be associated with massive layers from which there is little or no inflow to the well. In contrast, the deeper section with downward flow is characterized by diffuse inflow and outflow, resulting in a curved salinity profile (fig. $6 C$ ). What was interpreted as an upward flow step in figure $6 \mathrm{~A}$ can also be caused by downward flow in the borehole (fig. 6C). Similarly, what appears to be a downward flow step (fig. $6 B$ ) may be caused by upward flow in the borehole (fig. $6 D$ ).

Converging and Diverging Flow.-Converging flow may occur near an outflow zone as water flows both upward and downward within the borehole toward the outflow zone (fig. $6 E$ ). Diverging flow may occur near an inflow zone where water enters the borehole and flows both upward and downward within the borehole away from the inflow zone (fig. $6 F$ ). Because the aquifer salinity is unknown, it is not possible to determine unequivocally whether a converging or diverging flow condition exists solely by inspection of a measured salinity profile. 


\section{Length of Vertical Step}

Available salinity profiles for a given well indicate consistent steplike changes in salinity at the same depths under repeated profiling over several years. These steps likely reflect alternating hydraulically conductive and massive (relatively less hydraulically conductive) zones and vertical flow within the borehole. The heterogeneous and anisotropic nature of basalt aquifers in Hawai ' $i$ would tend to cause deviations from a smooth increase of salinity with depth in measured salinity profiles. Steps of different magnitude occur in all DMWs. Voss and Wood (1994) indicate, on the basis of borehole-flow measurements in southern $\mathrm{O}^{\prime}$ ahu, that water enters and leaves open boreholes through conductive zones and that these boreholeflow zones generally are limited in scale to lengths of less than about $66 \mathrm{ft}$. This length scale generally is consistent with the thickness of lava flows. Available data were insufficient to confirm whether inflows and outflows corresponded to conductive zones and whether zones of uniform salinity in measured profiles corresponded to massive low-permeability zones. Available data examined included caliper, spontaneous potential, resistivity, neutron, and gamma logs from various DMWs (unpub. data, HBWS and CWRM data files).

Regardless of the interpretation of borehole-flow direction, the vertical distance over which physical properties, such as salinity and temperature, remain uniform can be uniquely determined for each well. The longest vertical step or apparent displacement of salinity within the borehole (vertical distance over which salinity remains uniform) in each monitor well, considering all available profiles for that well, was used as an indicator of borehole flow in the well. A vertical step is defined by a zone of nearly uniform salinity, within a tolerance of plus or minus 0.1 percent seawater salinity, which is equivalent to a specific conductance of $55 \mu \mathrm{S} / \mathrm{cm}$. For each profile, every data point was compared to all other data points in the profile and the longest continuous depth interval in which salinity varies by less than plus or minus 0.1 percent of seawater salinity was identified (fig. 7). For some DMWs, only a segment of the entire salinity profile was analyzed to identify vertical steps, because vertical sections of near-uniform salinity in the profiles occur naturally in the freshwater and saltwater range that are not considered vertical steps. Exclusion zones were defined to exclude sections in some DMWs that were not interpreted to be vertical steps associated with borehole flow (table 3 ). The longest continuous interval from all profiles was designated as the single longest vertical step in each DMW (table 3). This method identifies only the single maximum vertical step, although additional smaller vertical steps may exist in the same profile (for example, Kaimukī Station DMW, Kalihi Station DMW, Moanalua DMW, or South Hālawa DMW). The length of the vertical step can be extended if the $55 \mu \mathrm{S} / \mathrm{cm}$ tolerance is increased. Profiles from the Punanani DMW between -340 and $-450 \mathrm{ft}$ (see fig. 15A) have specific-conductance increases of several hundred $\mu \mathrm{S} / \mathrm{cm}$ in multiple smaller steps.

The longest vertical steps in measured salinity profiles in Hawai' $i$ have lengths between several feet and several hundreds of feet (table 3). The longest individual step known is $644 \mathrm{ft}$ in Kaamilo DMW, and the shortest is $7 \mathrm{ft}$ in Kahalu 'u DMW. Shorter steps may not indicate borehole flow but simply reflect the heterogeneity of the basalt aquifer; longer steps greater than $70 \mathrm{ft}$ likely are related to borehole flow because the step length exceeds the typical thickness of lava flows. Spatially, a cluster
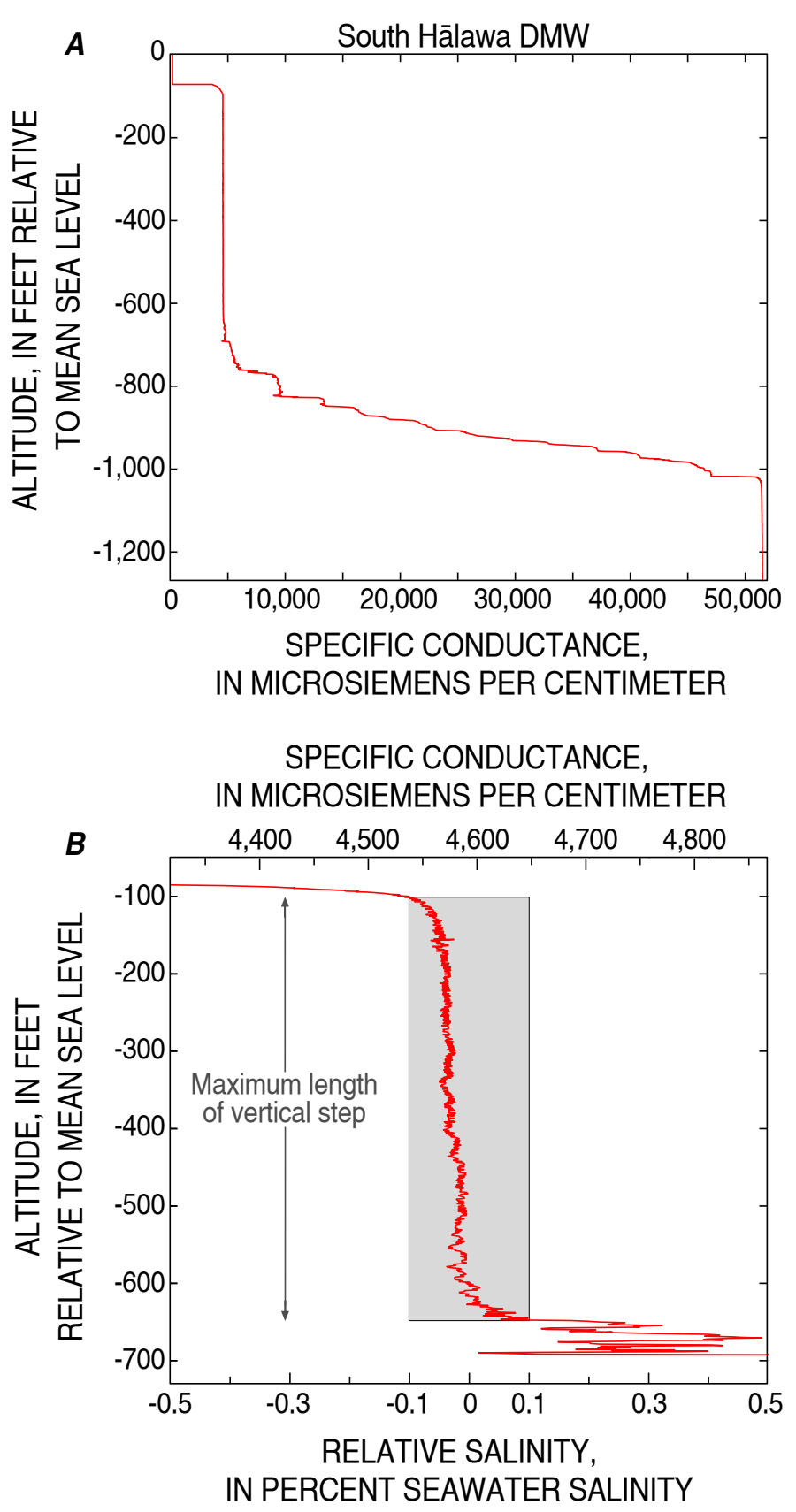

Figure 7. Salinity profile in South Hālawa DMW on 09/13/2001. $A$, Entire salinity profile. $B$, Closeup of the longest vertical step (outlined by gray box), with upper boundary at -102 feet and lower boundary at -647 feet relative to mean sea level, within which salinity varies by less than 0.1 percent of seawater salinity. 
of wells with long steps spans from northeast of Pearl Harbor to Honolulu (fig. 8). Other locations with long steps are in the Punalu ' $u$ area on the northeast coast of $\mathrm{O}^{\prime}$ ahu and the Waiehu area on Maui. Not surprisingly, areas of long vertical salinity steps in boreholes coincide with areas where monitor wells are located near large production wells. However, the distance between the production well and monitor well is not the only factor influencing the step length. The linear relation between distance of the closest major production well and maximum length of vertical step of salinity has a correlation coefficient of -0.25 and is statistically not significant at the 95 -percent confidence level $(p=0.11)$. Although DMWs with vertical steps

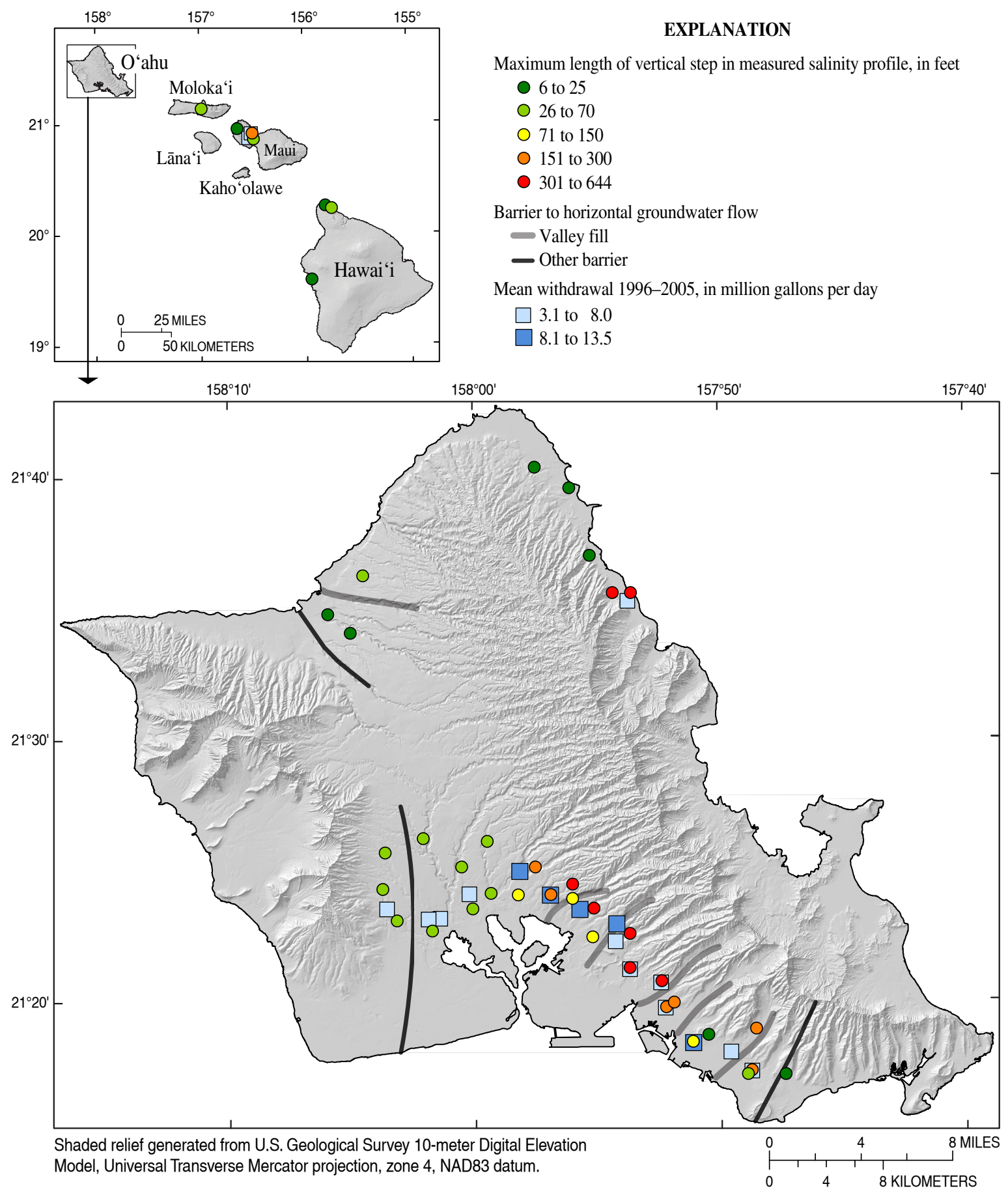

Figure 8. Maximum length of vertical step in measured salinity profiles in Hawai' $i$ and mean groundwater withdrawal rates during 1996 to 2005 from selected production wells and wellfields. The barriers to groundwater flow are modified from Oki (2005) and Rotzoll and El-Kadi (2007). 
Table 3. Specifications of the maximum vertical step of measured salinity, exclusion zones to identify the flow step, range of specific conductance above and within the vertical part of the step, and correlation coefficients and $p$ values from the regression analysis for the mean specific conductance within the vertical flow step near the apparent top of the transition zone versus nearby withdrawal rates and the depth of the apparent midpoint of the transition zone versus nearby withdrawal rates.

[ft, feet relative to mean sea level; $\mu \mathrm{S} / \mathrm{cm}$, microsiemens per centimeter; $R$, correlation coefficient between two random variables; $p$, calculated by transforming the correlation to create a $t$ statistic having $n$-2 degrees of freedom, where $n$ is the number of data points. If $p<0.05$, the hypothesis of no correlation is rejected at the $95 \%$ confidence level; --, not applicable; bold indicates statistically significant correlation at the $95 \%$ confidence level]

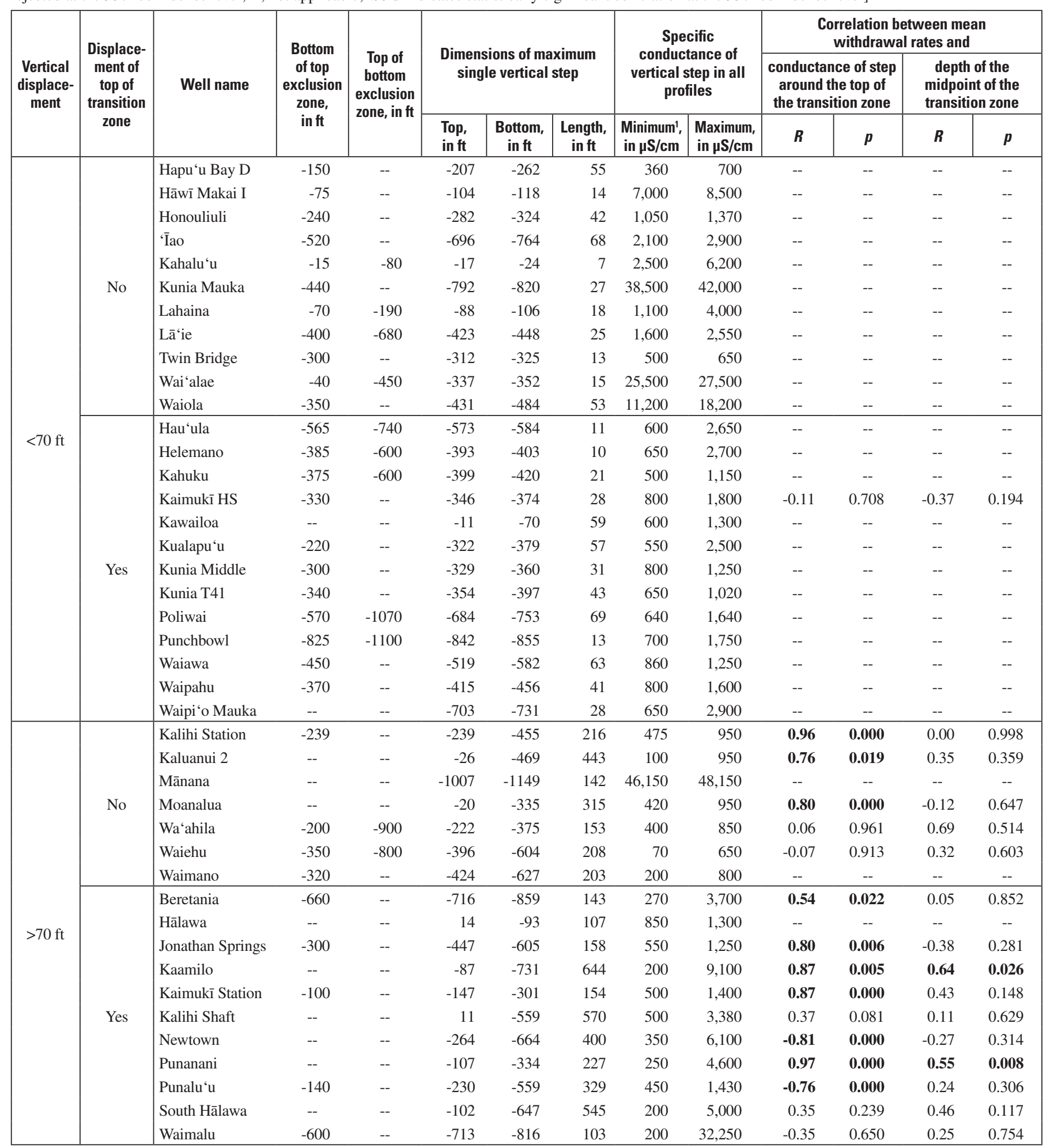

${ }^{1}$ Minimum refers to specific conductance immediately above the horizontal part of the step. 
of less than $70 \mathrm{ft}$ consistently are located greater than 1,000 ft from a production well, the opposite is not true. Monitor wells with long vertical steps in salinity profiles are located both close to production wells, for example Kalihi Shaft DMW (at $170 \mathrm{ft}$ ), and far from production wells, for example Newtown DMW or South Hālawa DMW. The latter DMWs are greater than 3,600 ft from major wellfields; other DMWs at similar distances have maximum vertical steps that are an order of magnitude shorter.

\section{Borehole-Flow Measurements}

Flow measurements within boreholes are available for several wells in Hawai 'i. Paillet and Hess (1995) measured flow with a heat-pulse flowmeter in Waipi 'o Mauka DMW, and Paillet and others (2002) used an electromagnetic flowmeter in Kaimukī Station DMW. Additional flow measurements with the electromagnetic flowmeter used by Paillet and others (2002) are available from Wai'alae DMW and Punanani DMW (D.S. Oki, U.S. Geological Survey, written commun., 2008). Data from each well are in the form of both trolling and stationary flow measurements. The stationary flow measurements were used to calibrate the continuous flow measurements collected by trolling. Although both yield comparable results (Newhouse and others, 2005), the stationary flow measurements are considered more reliable. Flow measurements are available from two monitor wells near production wells (Kaimukī Station DMW and Punanani DMW) and two monitor wells distant from production wells (Wai ‘alae DMW and Waipi'o Mauka DMW).

\section{Monitor Wells Near Production Wells}

The flow in monitor wells near production wells may be controlled directly by nearby groundwater withdrawals, which could obscure borehole flow caused by natural regional vertical hydraulic gradients in the aquifer. Flow was measured in Kaimukī Station DMW under two withdrawal rates from an adjacent production wellfield $(3.8 \mathrm{Mgal} / \mathrm{d}$ on May 22, 2001, and $7 \mathrm{Mgal} / \mathrm{d}$ on May 17, 2001). The flowmeter logs indicate high upward flow from -130 to $-380 \mathrm{ft}$ (fig. 9A). Highest upward flow occurs between -200 and $-300 \mathrm{ft}$, which overlaps the slotted interval of the production wells. In the shallowest parts of the monitor well, around $-100 \mathrm{ft}$, the flow is downward, indicating that water is converging towards the slotted interval of the production wells. Measured flow in the monitor well over the interval from -130 to $-380 \mathrm{ft}$ increased in response to an increase in withdrawal rate from the nearby wellfield. The measured flow pattern is consistent with steps observed in the specific-conductance logs (see fig. 14A). Between -530 and $-585 \mathrm{ft}$, a step consistent with diverging flow is observed in the specific-conductance profile in figure $9 A$. The flowmeter log indicates low upward flow near $-550 \mathrm{ft}$ and downward flow near $-590 \mathrm{ft}$, which is generally consistent with the steps in the conductance profile.
Additionally, between -650 and $-690 \mathrm{ft}$ a step consistent with downward flow in the specific-conductance profile coincides with downward flow near $-700 \mathrm{ft}$ in the flowmeter log. Other local spikes in the trolled flowmeter log over several tens of feet that can be attributed to changes in borehole diameter, for example at $-825 \mathrm{ft}$, are not reflected by steps in specificconductance profiles.

Flow measurements in Punanani DMW were taken when nearby groundwater withdrawal was $16.7 \mathrm{Mgal} / \mathrm{d}$. The flowmeter data indicate a similar flow pattern as in Kaimukī Station DMW. Flow is downward between -40 and $-100 \mathrm{ft}$, upward between -130 and $-450 \mathrm{ft}$, and low below $-460 \mathrm{ft}$ (fig. 9B). The observed upward flow pattern is consistent with the observed step in the specific-conductance profile over the same depth interval. Between -560 and -600 ft, a step in the specific-conductance profile coincides with downward flow between -530 and $-600 \mathrm{ft}$ in the flowmeter $\log$. The high variability in measured flow indicated by the continuous flowmeter log is attributed to variations in borehole diameter, as shown in the caliper log. Adjusting flow rates according to estimated borehole diameter did not entirely reduce the variability - the correction removed the scatter over one section but amplified it over other sections. Borehole flow can range from laminar to turbulent flow, which limits the utility of a well designed to monitor aquifer-salinity properties with depth.

\section{Monitor Wells Distant from Production Wells}

The magnitude of flow in monitor wells distant from production wells is expected to be lower than in monitor wells located near production wells, all other factors being equal. Reilly and others (1989) concluded that small vertical head gradients of $6.8 \times 10^{-5} \mathrm{ft} / \mathrm{ft}(0.4 \mathrm{ft} / \mathrm{mi})$ in the aquifer can cause borehole flow in long-screened wells. This could constrain the utility of the borehole for groundwater-quality monitoring, unless a more sophisticated approach is utilized by sampling well-bore flow and depth-dependent waterquality data (Izbicki and others, 1999). In Waipi 'o Mauka DMW, the flow measurements indicate a complex flow pattern with depth, alternating between upward and downward flow at intervals of 10-50 ft (fig. 10A). The stationary measurements indicate downward flow between -150 and -280 $\mathrm{ft}$ and between -450 and $-680 \mathrm{ft}$. Upward flow is indicated between -300 and $-400 \mathrm{ft}$ and between -720 and $-820 \mathrm{ft}$. At some depths, the stationary flow measurements are inconsistent with the continuous flowmeter measurements collected by trolling. Overall, the magnitude of the measured flow and the complex pattern of upward and downward flow indicate low overall flow in this monitor well.

Variations from upward to downward flow are less pronounced in Wai'alae DMW than in Waipi'o Mauka DMW. In Wai'alae DMW, all the flow above $-450 \mathrm{ft}$ is directed downward, an observation consistent with the regional flow concept for recharge areas (fig. 10B). The specific-conductance 
profile is characterized by an absence of long steps. A short step between -335 and $-350 \mathrm{ft}$ corresponds with downward flow in the stationary flow measurements.

\section{Comparison of Salinity and Temperature Profiles from Shallow and Deep Wells}

Comparing specific-conductance and temperature profiles from a pair of wells, one shallow and one deep, provides an indication of borehole flow in the deep wells. A shallow well that extends only into freshwater is less prone to borehole-flow effects because of its limited vertical extent. In the absence of borehole flow, the upper part of a specific-conductance profile from a DMW should be similar to the profile from a nearby shallow monitor well. Dissimilar salinity (or temperature) profiles are an indication of different flow conditions in the monitor wells. Temperature in wells unaffected by borehole flow generally decreases by several degrees Celsius with depth in the upper $50 \mathrm{ft}$ of the water column, remains nearly uniform over the next few hundred feet, and below that increases nearly linearly with depth following the geothermal
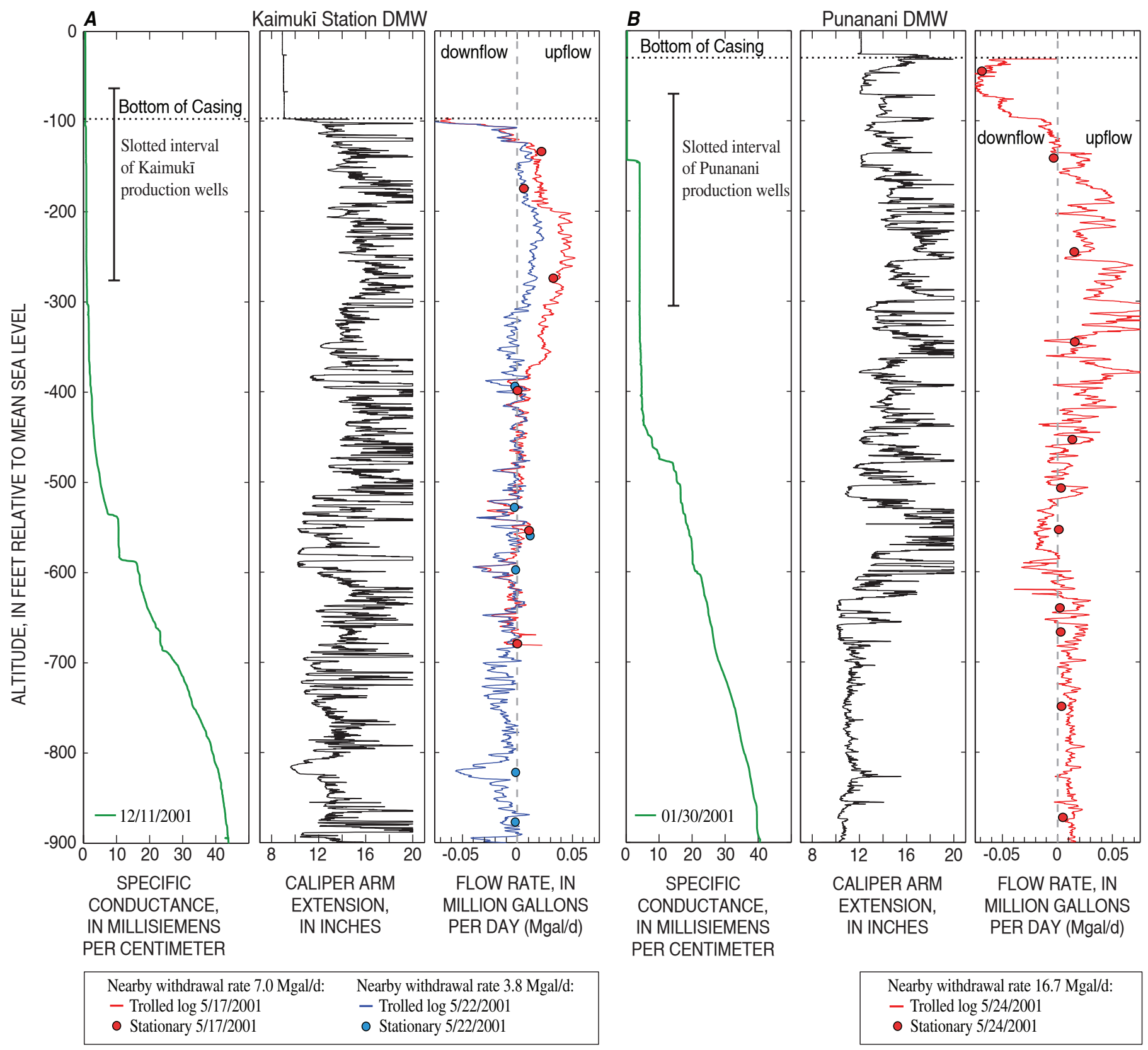

Figure 9. Specific-conductance, borehole diameter (caliper), and flowmeter measurements. A, Kaimuki Station DMW (modified from Paillet and others, 2002). B, Punanani DMW (unpub. data, USGS data files). The different pumping rates at nearby production wells at the times of the flow measurements are indicated. 
gradient. Salinity and temperature profiles from paired shallow and deep wells are available for monitor wells both near and distant from production wells (fig. 11).

Mānana DMW is located 1,200 ft from Mānana 1 (fig. 3), and the measured specific-conductance profiles from these wells generally are similar over the interval of the shallow well. The profiles were measured within 3 weeks of each other, during a period when no major changes from regional aquifer flow are expected. Small changes in specific conductance commonly are measured near the bottom of the solid casing of a monitor well. The specific-conductance profiles indicate freshwater in both wells to a depth of -140 ft (fig. $11 \mathrm{~A}$ ). The temperature is $0.25^{\circ} \mathrm{C}$ lower in the shallow well, but the shapes of the temperature profiles in the two wells are similar. The comparison of profiles from Mānana DMW and Mānana 1 indicates the absence of significant borehole flow in the upper part of the deep well, although vertical steps exist even above $-140 \mathrm{ft}$. This pair of shallow and deep wells is more than a mile away from a large wellfield.

Punanani DMW and two nearby shallow production wells, Punanani P1 and P2 located 100 and $25 \mathrm{ft}$ from Punanani DMW, were logged on the same day (fig. 11B).

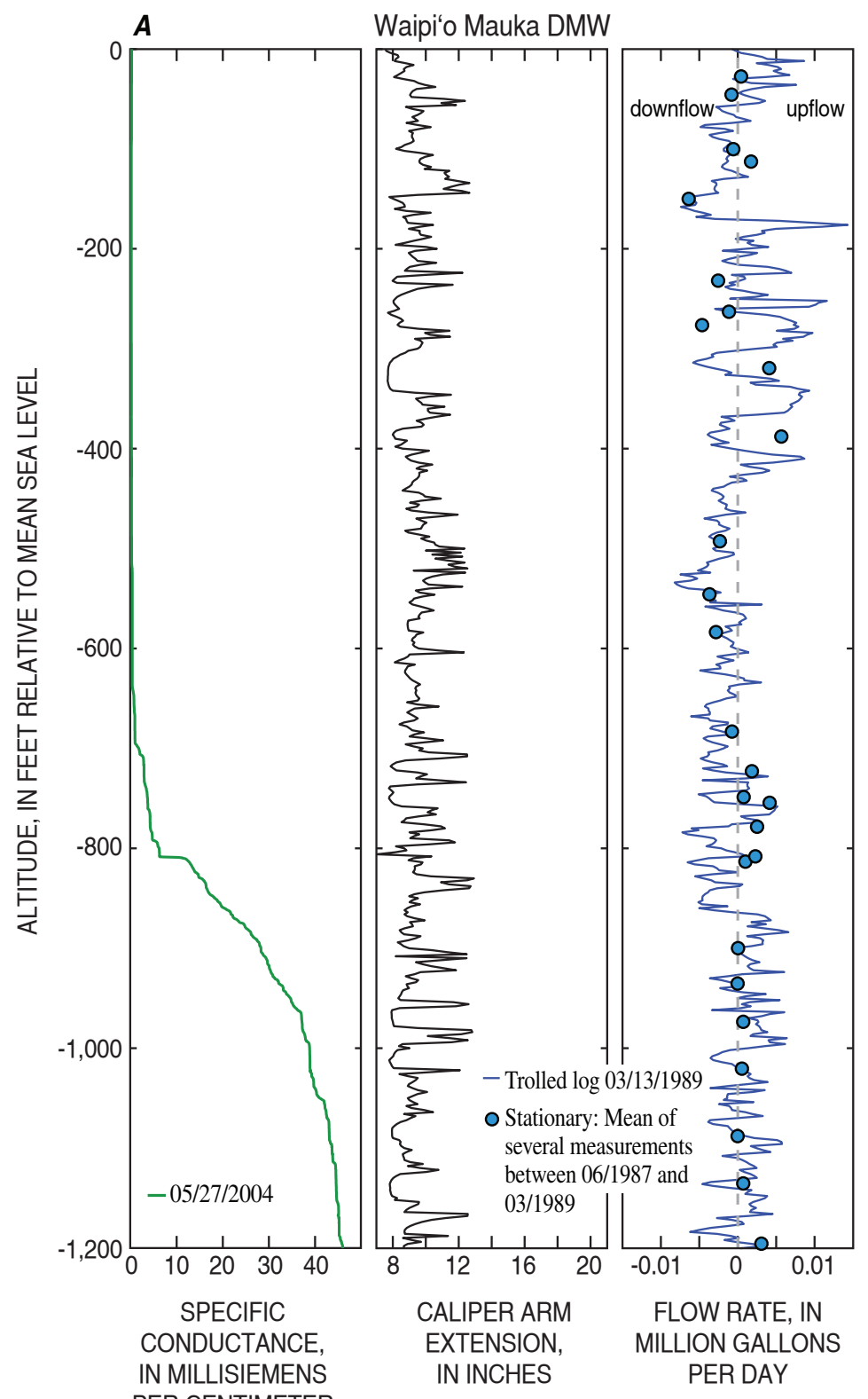

$B$

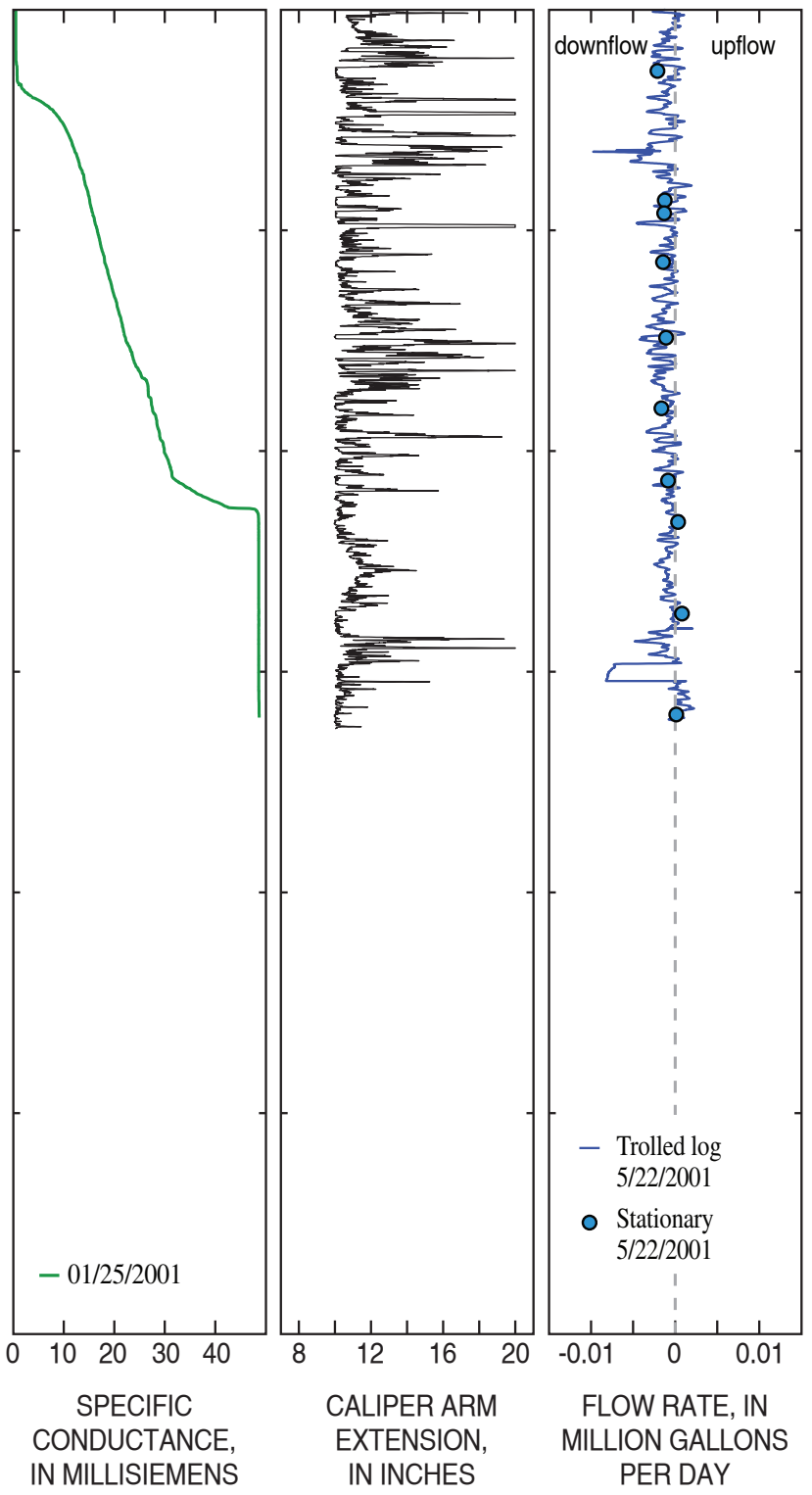

Figure 10. Specific-conductance, borehole diameter (caliper), and flowmeter measurements. $A$, Waipi'o Mauka DMW (modified from Paillet and Hess, 1995). B, Wa‘alae DMW (unpub. data, USGS data files). 
The shallow production wells were not in service during a pump-replacement period, though other wells in the Punanani wellfield were producing $6 \mathrm{Mgal} / \mathrm{d}$. The profiles from the shallow wells indicate freshwater over the entire lengths of the boreholes down to $-300 \mathrm{ft}$. However, the profile from the DMW shows a sharp specific-conductance increase at $-100 \mathrm{ft}$ to $2,100 \mu \mathrm{S} / \mathrm{cm}$, which remains nearly uniform to $-350 \mathrm{ft}$. The temperature in the shallow wells below about $-100 \mathrm{ft}$ is $0.25^{\circ} \mathrm{C}$ lower than in the deep well, indicating that warmer water from $-450 \mathrm{ft}$ is moving up the deep borehole and exiting at $-100 \mathrm{ft}$.
Thus, comparison of salinity and temperature profiles from the deep and shallow wells indicates that borehole flow is affecting the profiles from the deep well. In Punanani DMW the salinity profile is shifted to a more brackish profile, and the temperature profile is shifted to a warmer profile from the upward flow.

The same phenomenon is observed in Kaamilo DMW and the shallow Kalauao well, which is located $0.6 \mathrm{mi}$ from the Kaamilo DMW and within a production wellfield (fig. 3). The specific-conductance profile from the shallow well indicates freshwater, whereas the profile from the deep well
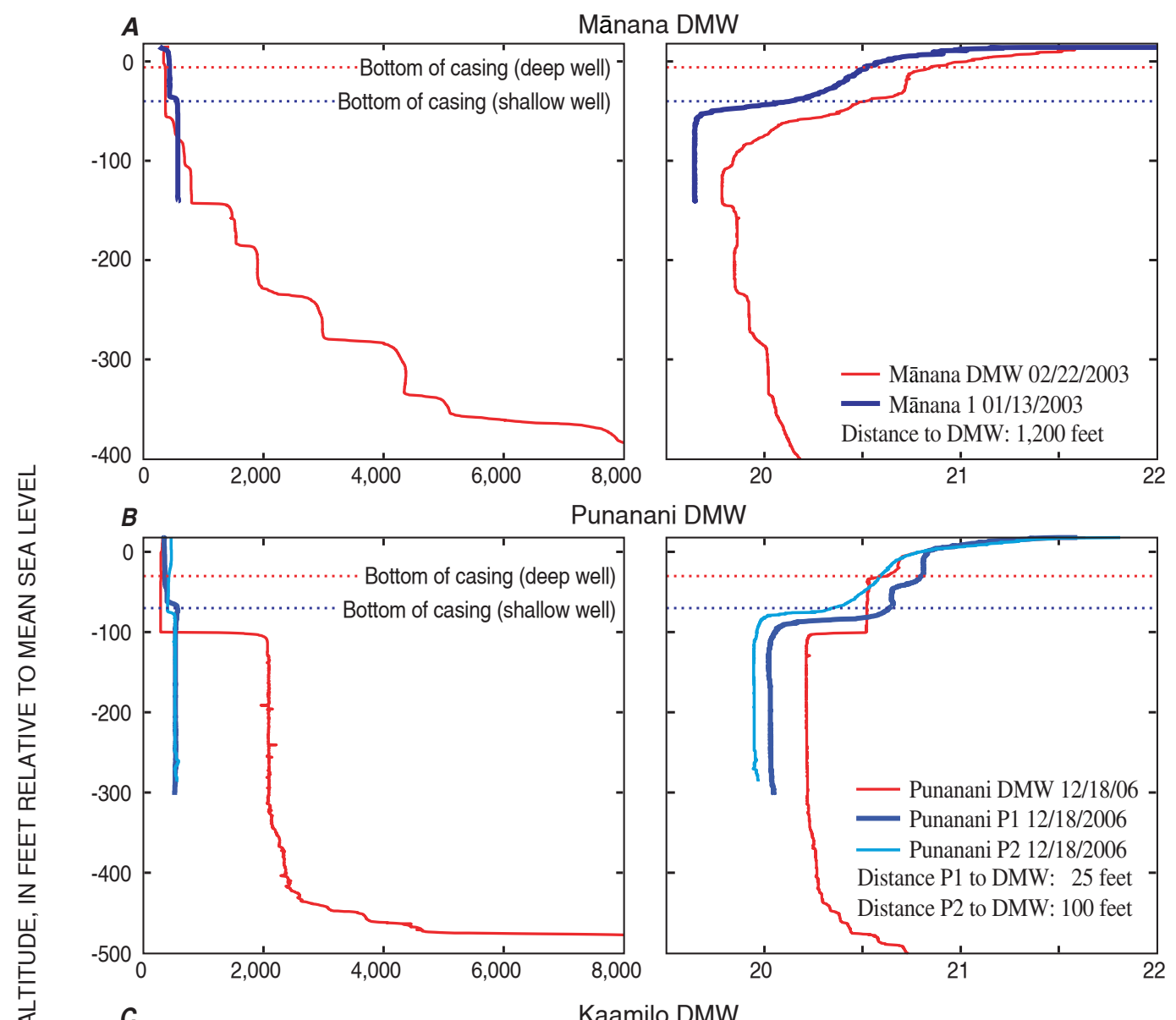

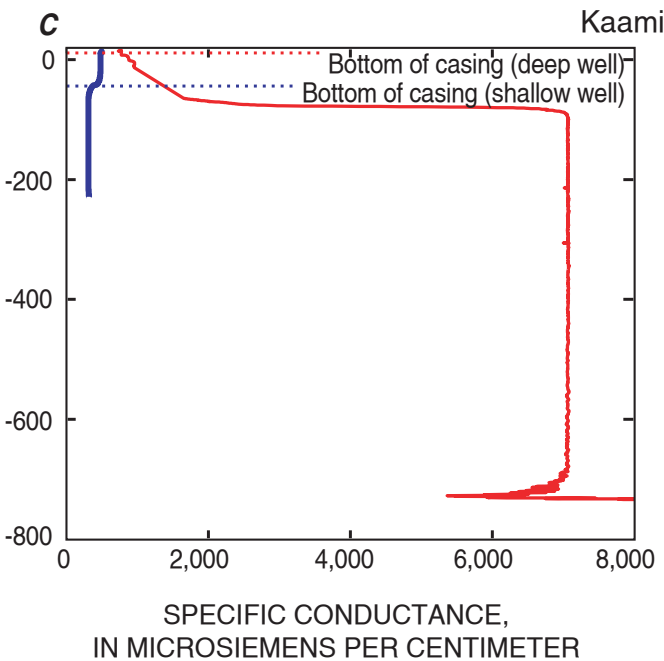

IN MICROSIEMENS PER CENTIMETER

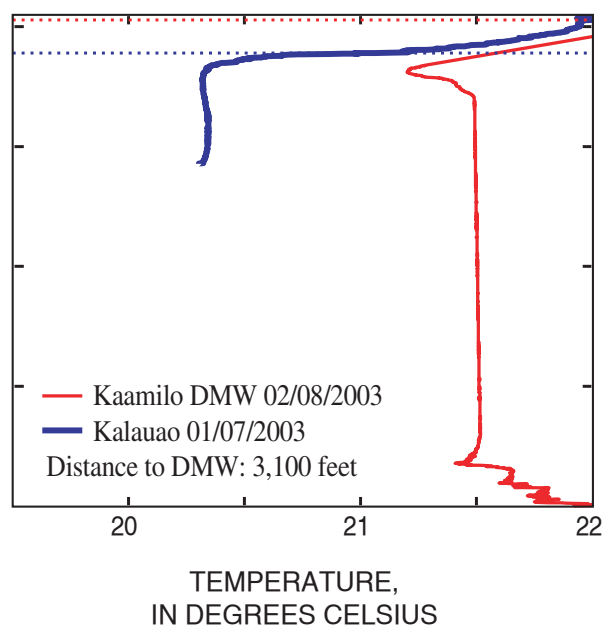

Figure 11. Paired specific-conductance and temperature profiles in shallow and deep monitor wells (DMW). A, Mānana DMW and Mānana 1. $B$, Punanani DMW and Punanani P1 and P2. C, Kaamilo DMW and Kalauao. 
indicates a salinity increase to $7,000 \mu \mathrm{S} / \mathrm{cm}$ between -80 and $-730 \mathrm{ft}$, which corresponds to brackish water (fig. $11 C$ ). The temperature profiles from the wells deviate below $-80 \mathrm{ft}$, where the temperature in the shallow well drops to $20.3^{\circ} \mathrm{C}$ and the temperature in the deep well remains nearly constant at $21.5^{\circ} \mathrm{C}$ through -730 ft. The shift in the profiles of the deep well to brackish and warmer water is another indicator of upward flow. Comparisons of profiles from shallow and deep monitor wells indicate that the measured salinities in the Punanani DMW and Kaamilo DMW are not representative of salinities in the surrounding aquifer.

\section{Effects of Groundwater Withdrawal on Salinity Profiles}

Regional groundwater withdrawals in Hawai 'i have caused a thinning of the freshwater lens over recent decades, reflected in salinity profiles by a rise of the apparent top and midpoint of the transition zone by several feet per year in many monitor wells (for example, Oki 2005; Gingerich, 2008). Salinity profiles in monitor wells also have been affected on shorter time scales by daily variations in pumping rates from nearby production wells. An example of how salinity and temperature profiles differ under nearby pumping and nonpumping conditions is available from logging done before and after a constant-rate aquifer test was conducted at Punanani wellfield (fig. 12). In this test, all pumping from production wells at the adjacent wellfield was curtailed for two days. The DMW was logged at the end of the water-level recovery phase and after pumping was resumed at the wellfield for 3.5 days at $12 \mathrm{Mgal} / \mathrm{d}$. At the end of the recovery phase, the step evident in the upper part of the salinity profile during pumping conditions (figs. $11 B, 12 A$ ) is absent (fig. 12A). Specific conductance gradually increases from $360 \mu \mathrm{S} / \mathrm{cm}$ at $-150 \mathrm{ft}$ to $2,000 \mu \mathrm{S} / \mathrm{cm}$ at $-360 \mathrm{ft}$ (fig. 12A). Similarly, the step evident in the temperature profile under pumping conditions is absent at the end of the recovery phase (figs. $11 B, 12 B$ ). Temperature gradually decreases with depth to $-300 \mathrm{ft}$ and increases nearly linearly with depth below $-450 \mathrm{ft}$ as a result of geothermal heating. After the 3.5 days of pumping, both salinity and temperature profiles indicate upward flow, because brackish and warmer water from about $-430 \mathrm{ft}$ is moved up the wellbore to $-125 \mathrm{ft}$, evident from the uniform specific conductance and isothermal conditions in this interval. Two days of recovery from pumping may not be long enough for the water column in the DMW to equilibrate to nonpumping conditions; however, the salinity and temperature profiles provide an indication of how borehole flow is affected by nearby groundwater withdrawals.

\section{Apparent Top of Transition Zone}

Steps in the upper part of specific-conductance profiles are compared to nearby withdrawal rates to investigate the influence of nearby groundwater withdrawals on the shape

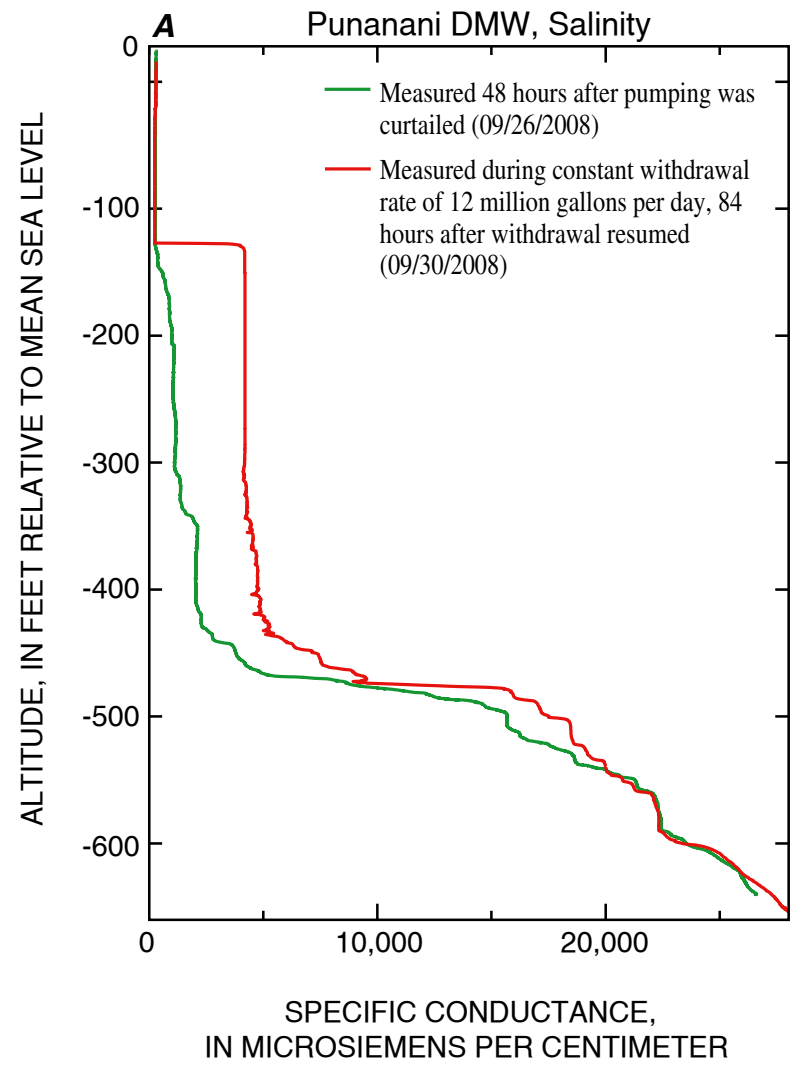

IN MICROSIEMENS PER CENTIMETER

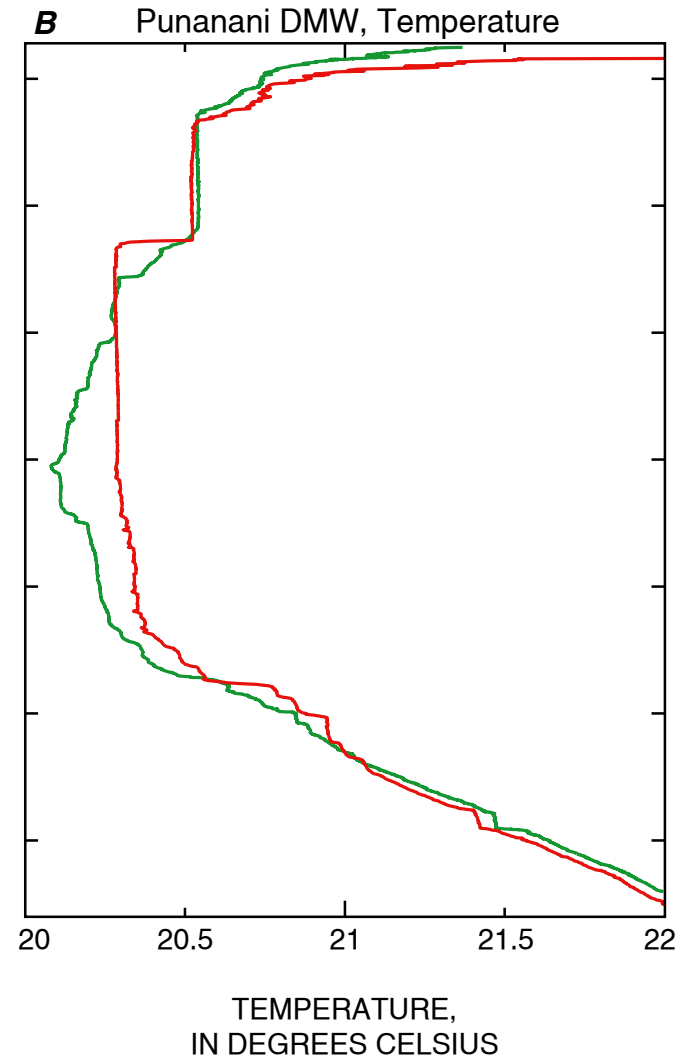

Figure 12. Salinity (A) and temperature (B) profiles obtained in Punanani DMW after pumping in the adjacent wellfield was curtailed for 48 hours and after pumping was resumed for 84 hours at a constant rate of 12 million gallons per day. 
of salinity profiles and the measured depth of the apparent top of the transition zone. The upward-flow step (fig. $6 \mathrm{~A}$ and figs. $11 B, C$ ) can be conceptually separated into horizontal and vertical parts. The vertical part, characterized by a nearly uniform specific-conductance value, is the section over which borehole flow occurs, and the horizontal part is where substantial outflow of water from the monitor well occurs. Steps in a profile can be characterized by (1) the depth of outflow, (2) the mean specific-conductance value of the vertical part, (3) the vertical distance over which borehole flow occurs, and (4) the change in specific conductance of the vertical part in different profiles. The change in specific conductance for upward flow is determined from the difference between maximum specific conductance of the vertical step and the specific conductance immediately above the horizontal part of the step (table 3). The difference represents the increase in salinity in the vertical-flow zone. The conductance above the flow step and maximum conductance of the step also define whether the $1,000 \mu \mathrm{S} / \mathrm{cm}$ specific-conductance value (corresponding to the top of the transition zone) is included in the step. For most days that a specific-conductance profile was available from a DMW, mean daily pumping rates from large nearby production wellfields were obtained to evaluate whether the average specific-conductance value of the vertical step in the profiles was significantly correlated to pumping rate. Profiles with evident vertical steps of salinity are separated into two categories - whether the apparent top of the transition zone $(1,000 \mu \mathrm{S} / \mathrm{cm}$ specific-conductance value) is included in the vertical step in the profile or not.

\section{Apparent Top of Transition Zone Not Included Within the Longest Vertical Step}

Salinity profiles from wells in this category have a vertical step of specific conductance that is longer than $70 \mathrm{ft}$, but the maximum specific conductance within the longest vertical step is less than $1,000 \mu \mathrm{S} / \mathrm{cm}$. However, this does not preclude the possibility that borehole flow may affect monitoring of the apparent top of the transition zone sometime in the future, when the specific-conductance value of the longest vertical step exceeds $1,000 \mu \mathrm{S} / \mathrm{cm}$, or even currently for a shorter vertical step occurring below the longer one.

Figures 13, 14, and 15 all have a similar layout as described here. In the large main plot for a particular well, selected specific-conductance profiles are color-coded to show extreme (minimum and maximum specific conductance) cases of the vertical step (green and red) and intermediate cases (yellow and orange). The gray box defines the common depth interval of all salinity profiles over which the nearly constant specific-conductance values of the flow step are averaged for analysis in the lower plot. The black bracketed line indicates the slotted interval of nearby production wells. The slotted intervals of the production wells were vertically shifted to account for dip of the lava flows along their principal flow direction $\left(\mathrm{O}^{\circ}\right.$ ahu $3^{\circ}$ and west Maui $\left.8^{\circ}\right)$ and the distance to the DMW. The vertical dashed line corresponds to the
$1,000 \mu \mathrm{S} / \mathrm{cm}$ specific-conductance value, indicative of the top of the transition zone. In the lower plot for each well, the mean specific conductance of the vertical flow step is plotted relative to the daily mean withdrawal rate. Data points corresponding to profiles shown in the plot immediately above are coded with the same color as the profiles, whereas other available profiles, not shown in the upper plot of profiles, are shown as blue dots. Withdrawal rates were not available for all days when profiles were collected. The black line in the lower plot is a leastsquare fit line for all data points, and the gray lines are the 95-percent confidence intervals of one standard deviation of the regression. The correlation coefficient, $R$, is shown in the corner of the plot. Additionally, to test for statistical significance of the correlation, a $p$ value is provided (table 3 ). The $p$ value is calculated by transforming the correlation between two parameters to create a t statistic having $n-2$ degrees of freedom, where $n$ is the number of data points (Helsel and Hirsch, 1992). For correlations with a $p$ value smaller than 0.05 , the hypothesis of no correlation between the parameters has to be rejected at the 95-percent confidence level. Lower $p$ values correspond to greater confidence in the correlation between the two parameters.

Three examples of DMWs are described below in which the longest vertical step in salinity profiles currently does not affect monitoring the apparent top of the transition zone. The first example is from Kalihi Station DMW (fig. 13A). A uniform specific conductance between about -240 and $-450 \mathrm{ft}$ is consistent with upward flow over about $200 \mathrm{ft}$. The upward flow terminates when it reaches the bottom of the solid casing of the monitor well at $-239 \mathrm{ft}$. The mean specific conductance of the vertical section of the step varies temporally between 475 and $950 \mu \mathrm{S} / \mathrm{cm}$, and the specific conductance and nearby withdrawal rates are strongly correlated (correlation coefficient of 0.96 and statistically significant $p$ value) (table 3 ). Although the longest vertical step does not include the apparent top of the transition zone, a second flow step between about -450 and $-485 \mathrm{ft}$ does. The depth difference of the apparent top of the transition zone in the green and the red profiles is $80 \mathrm{ft}$ (fig. 13A).

Salinity profiles from the Moanalua DMW are affected by nearby groundwater withdrawals (fig. 13B). The longest flow step stretches vertically over $315 \mathrm{ft}$, and two more steps affect $90 \mathrm{ft}$ of the profile below the main step. The mean specific conductance of the vertical section of the longest step varies temporally between 420 and $800 \mu \mathrm{S} / \mathrm{cm}$, although one profile from 2003, not shown in fig. $13 B$ because the withdrawal rate was unavailable, is at $950 \mu \mathrm{S} / \mathrm{cm}$. The correlation coefficient of the linear relation between mean specific conductance of the vertical step and daily mean withdrawal rate is lower (0.80) than that associated with Kalihi Station DMW, but it is statistically significant at the 95-percent level. The main vertical step does not affect the apparent top of the transition zone. However, the second and third step below -340 $\mathrm{ft}$ do affect the $1,000-\mu \mathrm{S} / \mathrm{cm}$ threshold. The apparent top of transition zone differs by $80 \mathrm{ft}$ between the green and the red profile (fig. 13B). 

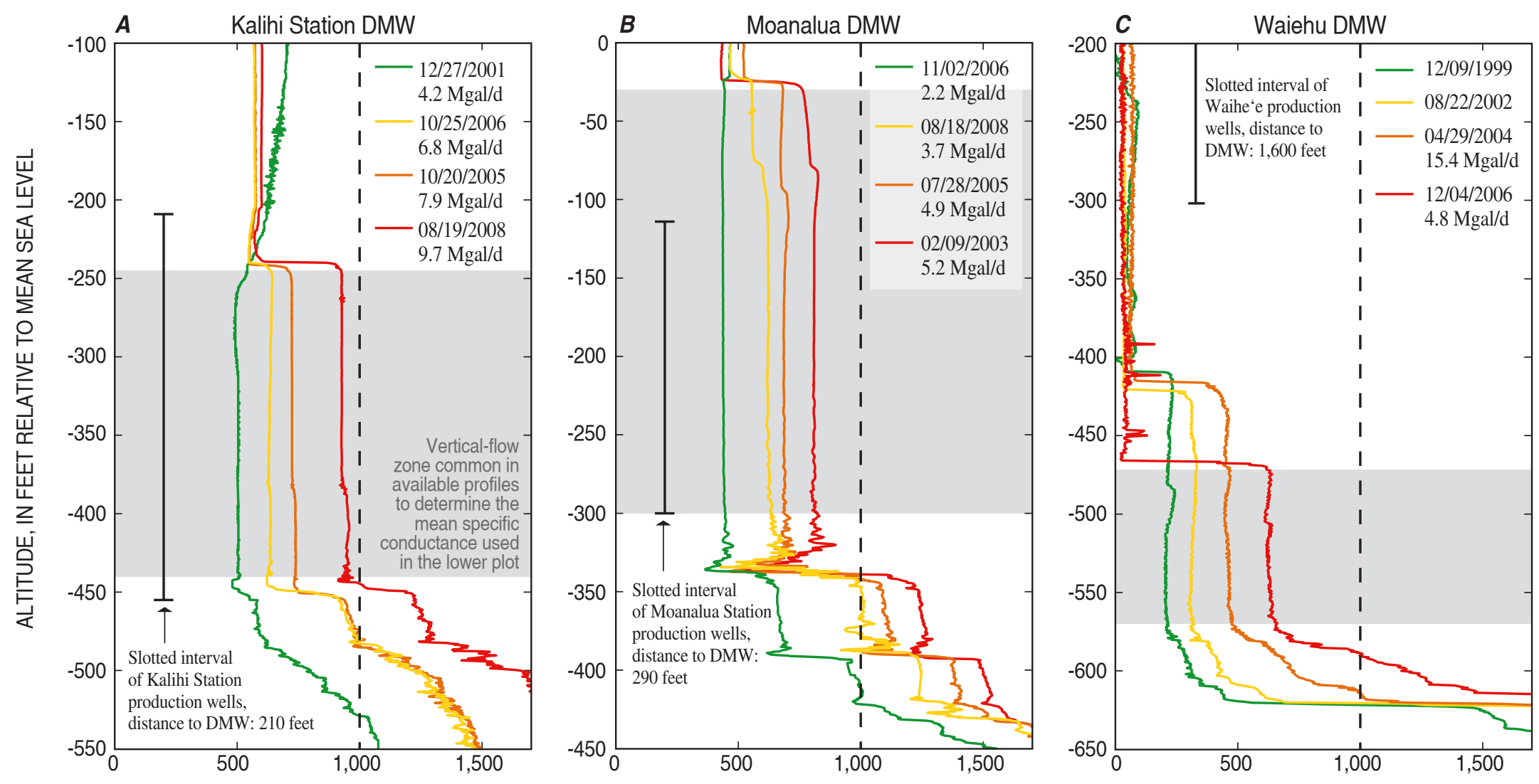

SPECIFIC CONDUCTANCE, IN MICROSIEMENS PER CENTIMETER
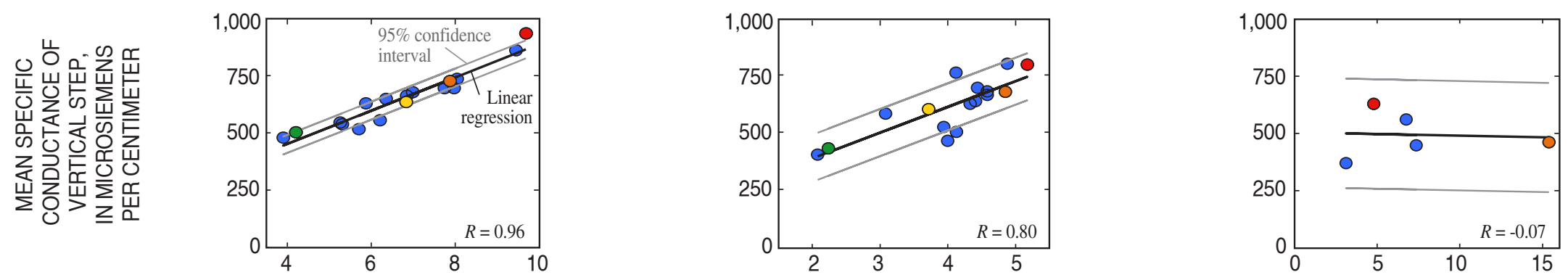

MEAN DAILY WITHDRAWAL RATE, IN MILLION GALLONS PER DAY (Mgal/d)

Figure 13. Selected profiles in which the longest vertical step in salinity does not include the 1,000 microsiemens per centimeter specific-conductance value. $A$, Kalihi Station DMW. B, Moanalua DMW. C, Waiehu DMW. See text for full explanation of plots and symbols. 
The third example is Waiehu DMW on Maui (fig. 13C). The observed specific-conductance values of the flow step show poor correlation with the available daily withdrawal rates. The upward flow step affects at least $100 \mathrm{ft}$ in most of the profiles, but currently not the apparent top of transition zone, although that depth in the red profile is $40 \mathrm{ft}$ shallower than in the green profile. The depth of the horizontal part of the step generally increases as the specific conductance of the vertical step increases. This phenomenon also occurs in other wells, for example in Kaamilo DMW and Newtown DMW. The Kalihi Station and Moanalua DMWs are less than $300 \mathrm{ft}$ from production wells, whereas the Waiehu DMW is five times farther from production wells (Kaamilo DMW and Newtown DMW are more than ten times farther). Short-term variations in withdrawal rates from production wells may not affect borehole flow in distant DMWs. The observed flow step in profiles from the Waiehu DMW could be a result of regional drawdown of the upper part of the freshwater lens over longer periods (several years to decades).

Scatter around the regression lines in the bottom plots in figures $13 A, B$ may be related to limitations of using daily mean withdrawal rates for the analysis. Because groundwater withdrawal generally is unequally distributed throughout the day, the mean value could underestimate or overestimate the withdrawal rate at the time the monitor well was logged. In addition, the withdrawal rate from nearby production wells may change while the monitor well is being logged. A few profiles may have been affected by changing withdrawal rates. These profiles indicate changes of specific-conductance values with depth over the part of the profile that otherwise has a uniform specific-conductance value in most other available profiles. Detailed data on withdrawal rates during the day were not available to evaluate whether the withdrawal rate changed during the periods when wells were logged. Nevertheless, profiles without a pronounced vertical step in specific conductance were excluded from the regression analysis.

Correlating specific-conductance values of vertical steps in profiles with daily mean withdrawal rates also may have limitations for monitor wells located distant from production wells. Variations in salinity profiles may not be related to the amount of withdrawal from a distant production well on the day the monitor well was logged. Instead, variations in salinity profiles may be affected by withdrawals on a regional scale. Regional drawdown may be enhanced in the aquifer systems of Honolulu and east Pearl Harbor because of compartmentalization by low-permeability valley fills (fig. 8), inland dikes, and the coastal caprock (fig. 5).

Although the apparent top of the transition zone is not included in the longest step for wells in this category, the maximum specific conductance of the longest step is commonly only slightly less than $1,000 \mu \mathrm{S} / \mathrm{cm}$. The longest vertical step may include the apparent top of the transition zone in the future because of increased withdrawals or decreased recharge, or because the salinity at the inflow position of the step increases because of a shrinking freshwater lens.
Moreover, monitoring the apparent top of the transition zone using profiles from Kalihi Station DMW, Moanalua DMW, and Waiehu DMW may not be appropriate because shorter steps below the longest one already include the apparent top of the transition zone.

\section{Apparent Top of Transition Zone Included Within the Longest Vertical Step}

For all available salinity profiles from wells in this category, the specific conductance above the longest vertical step is less than $1,000 \mu \mathrm{S} / \mathrm{cm}$ and the maximum observed mean specific conductance within the step is greater than $1,000 \mu \mathrm{S} / \mathrm{cm}$. Monitoring the top of the transition zone using profiles from these wells may not be appropriate. Examples of monitor wells with profiles that have vertical steps of salinity induced by nearby or regional withdrawals that include the apparent top of transition zone salinity, depending on the withdrawal rate, include Kaimukī Station DMW, Jonathan Springs DMW, and Punalu'u DMW.

Salinity profiles from the Kaimukī Station DMW indicate a vertical step with mean specific conductance greater than $1,000 \mu \mathrm{S} / \mathrm{cm}$ for high withdrawal rates from nearby production wells (fig. 14A). The longest step stretches vertically over $150 \mathrm{ft}$, although it could be extended over $200 \mathrm{ft}$ if the shorter step above it is included. Another nearly vertical step between -300 and $-370 \mathrm{ft}$ is present in some profiles (yellow, orange, and red profiles in fig. 14A) but not in others that were measured under relatively lower withdrawal rates (green profile in fig. 14A).

The specific conductance of the vertical step ranges from 500 to $1,400 \mu \mathrm{S} / \mathrm{cm}$ in available profiles. The correlation between mean specific conductance of the step and nearby withdrawal rate is statistically significant. Tracking the depth of the 1,000$\mu \mathrm{S} / \mathrm{cm}$ specific-conductance value in profiles from this well may not provide a meaningful indicator of water-quality changes in the aquifer. For the profiles measured under low nearby withdrawal rates (less than $4 \mathrm{Mgal} / \mathrm{d}$ ), the apparent top of the transition zone is between -325 and $-300 \mathrm{ft}$. For withdrawal rates greater than $4 \mathrm{Mgal} / \mathrm{d}$, the depth of the $1,000 \mu \mathrm{S} / \mathrm{cm}$ specific-conductance value occurs at a much shallower altitude near $-110 \mathrm{ft}$, within the horizontal part of the step in the profile. The change in the depth of the apparent top of the transition zone is not caused by upconing (upward movement of brackish water beneath an active production well) and does not reflect an overall change of salinity in the adjacent aquifer. Instead, it can be attributed to upward flow in the monitor well induced by nearby withdrawals from production wells located only $70 \mathrm{ft}$ away.

The apparent top of the transition zone in profiles from Jonathan Springs DMW also is affected by withdrawals (fig. $14 B$ ). The vertical step between -480 and $-580 \mathrm{ft}$ is not as pronounced as in profiles from other wells, and several smaller steps occur in the upper part of the specific-conductance profile. The monitor well is 2,300 ft from the nearest large production wells. All other factors being equal, the farther a monitor well is from production wells, the smaller is the effect 

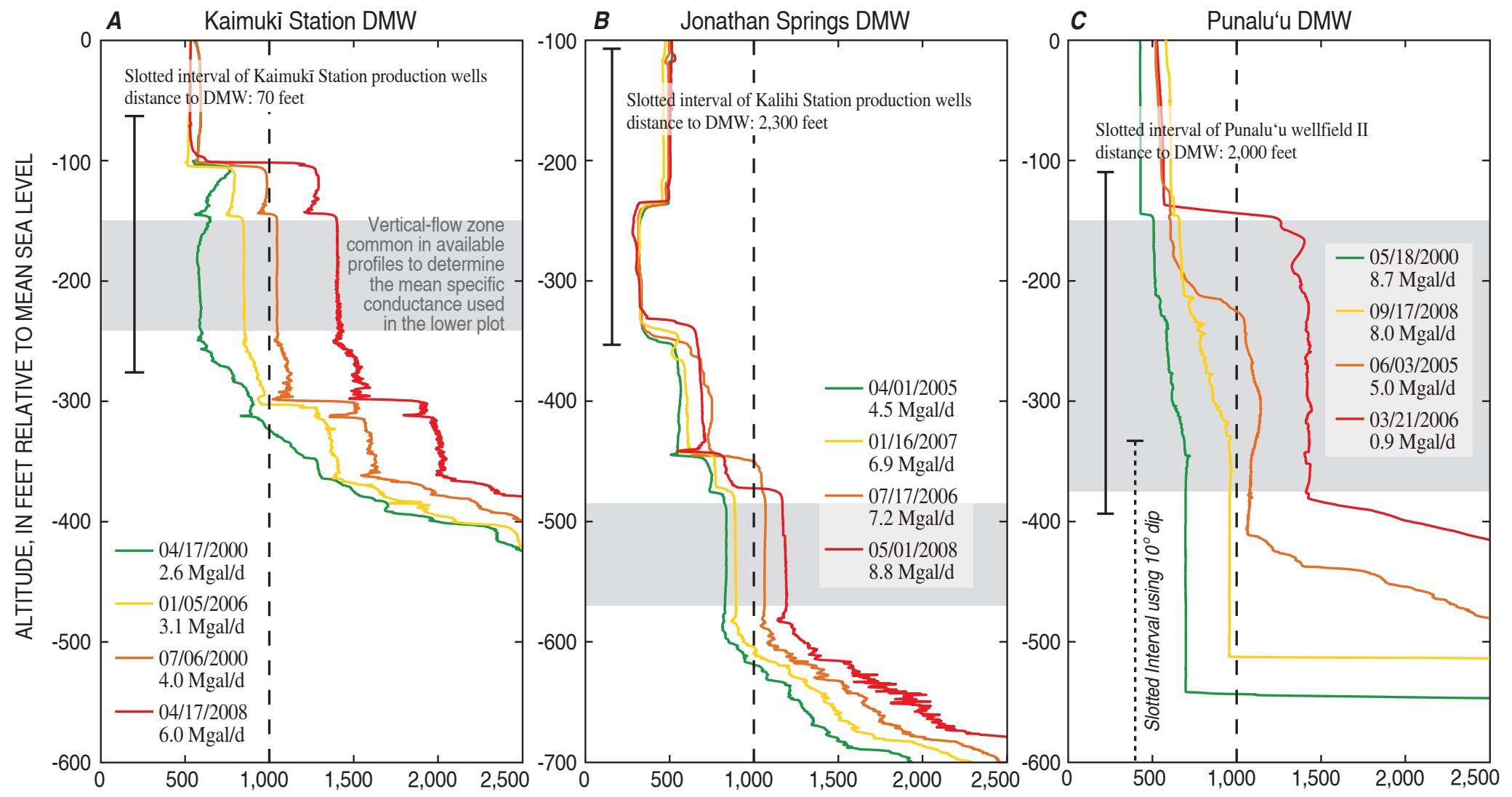

SPECIFIC CONDUCTANCE, IN MICROSIEMENS PER CENTIMETER
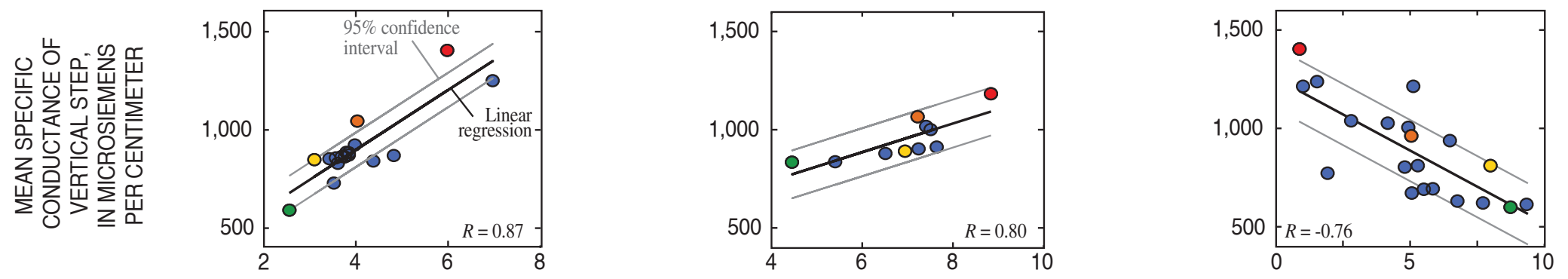

MEAN DAILY WITHDRAWAL RATE, IN MILLION GALLONS PER DAY (Mgal/d)

Figure 14. Selected profiles in which the longest vertical step in salinity includes the 1,000 microsiemens per centimeter specific-conductance value, depending on the withdrawal rate from nearby or regional withdrawals. A, Kaimuki Station DMW. B, Jonathan Springs DMW. C, Punalu'u DMW. See text for full explanation of plots and symbols. 
of withdrawals on measured salinity profiles. However, the mean specific-conductance values of the step in the profiles are significantly correlated with daily mean withdrawal rates from the nearest production wells. The specific-conductance value of the step ranges from 830 to $1,250 \mu \mathrm{S} / \mathrm{cm}$, and the depth of the apparent top of the transition zone varies by $160 \mathrm{ft}$ in profiles from this monitor well, depending on the withdrawal rate of the production wells.

The longest vertical step in some salinity profiles from Punalu' $u$ DMW is between -150 and $-400 \mathrm{ft}$ and between -250 and $-560 \mathrm{ft}$ in other profiles. The mean specific-conductance values of the extensive step are negatively correlated with daily mean withdrawal rates from nearby production wells (fig. 14C). The significant negative correlation $(R=-0.76)$ indicates that higher withdrawal rates from the production wells cause lower specific conductance in the vertical steps of the profiles and a deeper apparent top of the transition zone. In fact, the highest specific-conductance value of the longest step in the profile is associated with the lowest withdrawal rate $(0.9 \mathrm{Mgal} / \mathrm{d})$, and the lowest specific-conductance value is associated with the highest withdrawal rate $(8.7 \mathrm{Mgal} / \mathrm{d})$. The shape of the profiles may indicate upward flow (see fig. 6A) from about -400 to $-150 \mathrm{ft}$ associated with the orange and red profiles, but downward flow (see fig. $6 B$ ) from about -350 to $-560 \mathrm{ft}$ associated with the yellow and green profiles (fig. $14 C$ ). It appears that under high withdrawal rates downward flow is induced in the borehole. Punalu 'u II wellfield is located inland from the monitor well (fig. 3), and the slotted interval of the production wells may therefore affect a deeper section in the monitor well because of the dip of the lava flows. However, the assumed dip of $3^{\circ}$ is near the lower end of the range of reported angles. If the maximum reported dip of $10^{\circ}$ is assumed, the slotted interval of the production wells would affect a deeper part of the monitor well, between -330 and $-620 \mathrm{ft}$, and this is consistent with the observed depth of outflow from the profiles with a downward-flow step. The monitor well is located $420 \mathrm{ft}$ from the coast, where upward flow driven by the regional flow system is expected. Thus, during periods of low groundwater withdrawal, the natural hydraulic gradient in the aquifer may cause upward flow in the borehole, whereas during periods of high withdrawal downward borehole flow may be induced.

In the examples presented above, the apparent top of transition zone changed hundreds of feet depending on the withdrawal rate, and the specific-conductance value of the vertical step in the profile exceeded $1,000 \mu \mathrm{S} / \mathrm{cm}$ for some withdrawal rates. Cases also exist in which the $1,000-\mu \mathrm{S} / \mathrm{cm}$ depth in profiles is included in the longest vertical step for all available (nonzero) withdrawal rates. Three examples (Punanani DMW, Kaamilo DMW, and Kalihi Shaft DMW) are described below.

Specific conductance along the vertical part of the step in profiles from the Punanani DMW (fig. 15A) ranges from 300 (zero withdrawal from nearby production wells) to $4,600 \mu \mathrm{S} / \mathrm{cm}$ in available profiles and stretches over $230 \mathrm{ft}$ in some profiles. The depths of outflow from the upwardflow steps coincide with the slotted interval of the nearby production wells. The withdrawal of groundwater from the Punanani production wells started in 1972. The specificconductance profile from 1968 is therefore representative of the conditions in the monitor well before nearby groundwater withdrawal started. The profile from 1968 shows an apparent top of transition zone at $-560 \mathrm{ft}$ and no clear indication of an upward-flow step. A similar profile was available from September 2008, when pumping at the Punanani wellfield was curtailed for two days (fig. 12). Available data from the Punanani DMW indicate that upward borehole flow is directly induced by nearby withdrawals, and if nearby withdrawals cease then the upward borehole flow mainly is eliminated. The significant correlation $(R=0.97)$ between daily mean withdrawal rate and specific conductance of the vertical step is supported by little scatter around the regression (table 3 ). The slope of the regression line indicates that for a $1 \mathrm{Mgal} / \mathrm{d}$ increase in withdrawal rate the specific-conductance value of the step in the profile between -160 and $-320 \mathrm{ft}$ increases by $275 \mu \mathrm{S} / \mathrm{cm}$. The six production wells at the Punanani wellfield are located in close proximity (between 25 and $140 \mathrm{ft}$ ) to the monitor well, and withdrawals from these wells induce upward flow in Punanani DMW, which drastically shifts the depth of the apparent top of the transition zone upward and misrepresents its position in the aquifer. Despite this, monitoring the midpoint of the transition zone is still valuable.

A longer upward-flow step is observed at Kaamilo DMW. In some profiles, the step stretches over $644 \mathrm{ft}$, and the specific-conductance values increase to $9,100 \mu \mathrm{S} / \mathrm{cm}$ (fig. 15B). A profile taken under no or low withdrawal conditions does not exist to verify whether the step disappears under those conditions. The depth of outflow corresponds to the slotted intervals of Kalauao and Kaamilo production wells. Although the major production wells at Kalauao are $0.6 \mathrm{mi}$ from the monitor well, a significant relation exists between daily mean withdrawal rate and specific conductance of the vertical step in the profile from the monitor well. The aquifer between the monitor well and production wells may be hydraulically well connected, for example by a lava tube, or the aquifer may be compartmentalized to an extent that causes regional drawdown to extend to the monitor well. Available data appear to fall into two separate groups (see small plot fig. $15 B$ ). The data collected during 2001 to 2003 indicates a separate relation relative to the data collected since 2005, although the relations have similar slopes. The separate relations may be associated with separate factors, including nearby withdrawal, regional drawdown, or changes in recharge. Regional pumping effects in compartmentalized aquifers can cause a hydraulic gradient that induces upward flow in a distant monitor well. The apparent midpoint of the transition zone between freshwater and saltwater has risen several feet per year in the Kaamilo DMW because of long-term regional withdrawals and low recharge (Rotzoll and others, 2010). Hence, the uniform specific conductance of the flow step increases over time, because of a rise of the transition zone in the aquifer and because the inflow at the bottom of the flow step remains at the same altitude because of geologic constraints. 

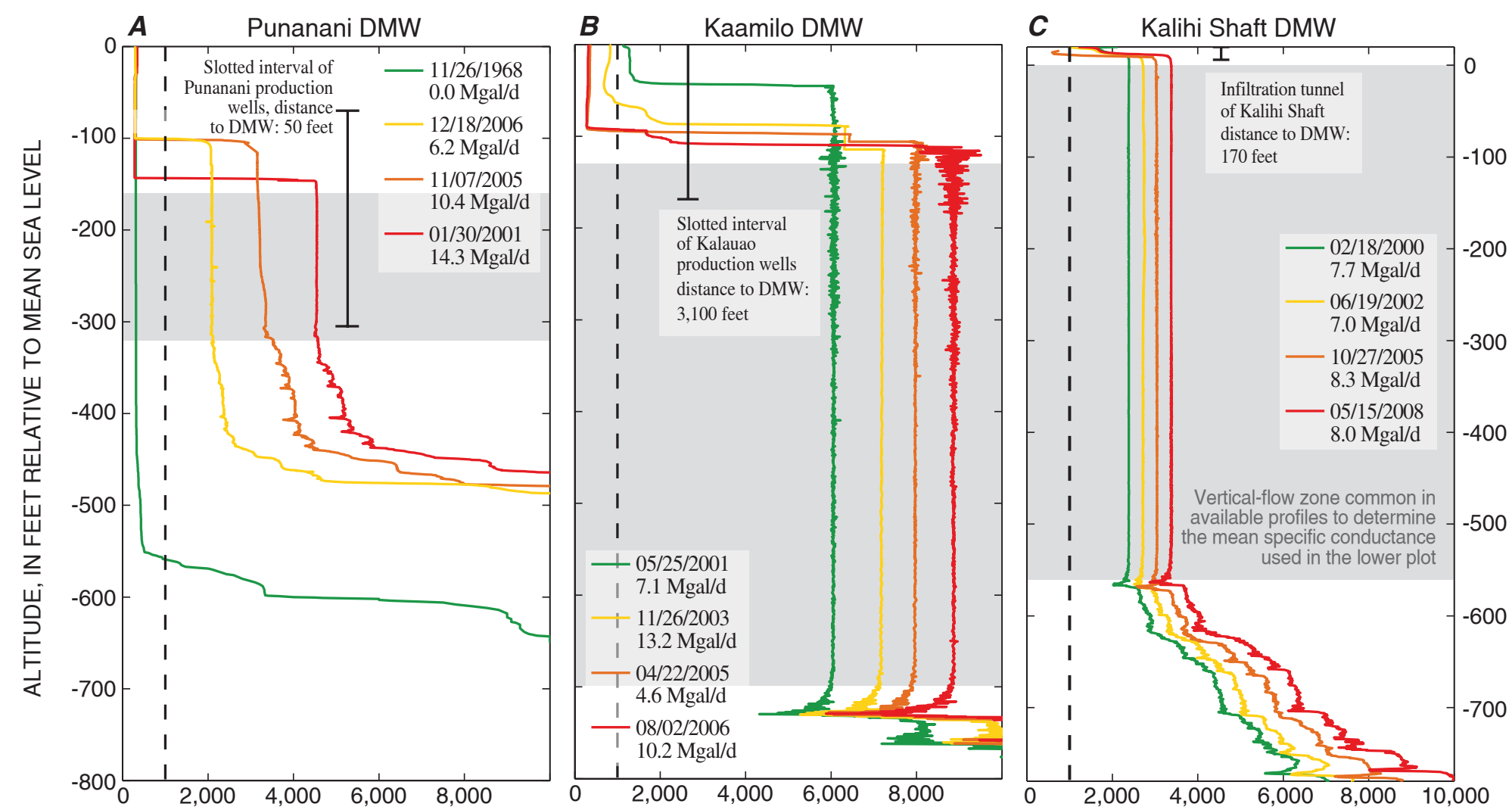

SPECIFIC CONDUCTANCE, IN MICROSIEMENS PER CENTIMETER
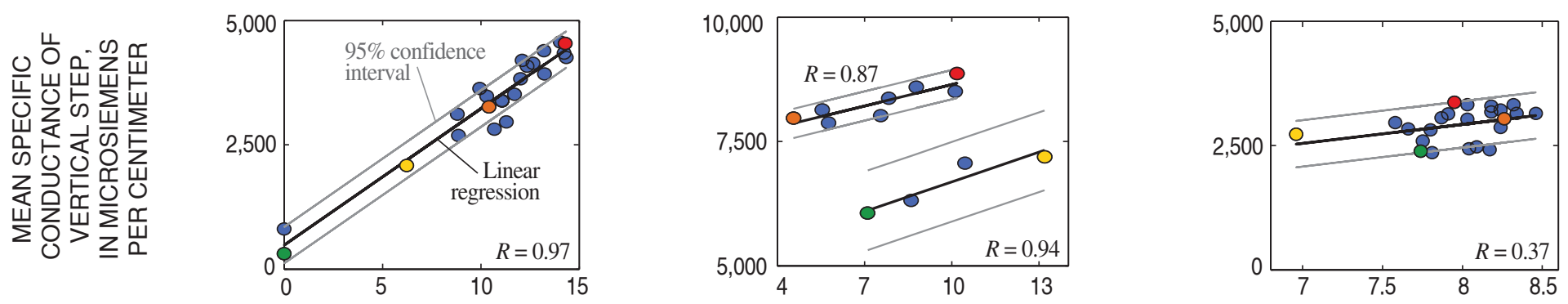

MEAN DAILY WITHDRAWAL RATE, IN MILLION GALLONS PER DAY (Mgal/d)

Figure 15. Selected profiles in which the longest vertical step in salinity, induced by nearby or regional withdrawal, is persistent and includes the 1,000 microsiemens per centimeter specific-conductance value. A, Punanani DMW. B, Kaamilo DMW. C, Kalihi Shaft DMW. See text for full explanation of plots and symbols. 


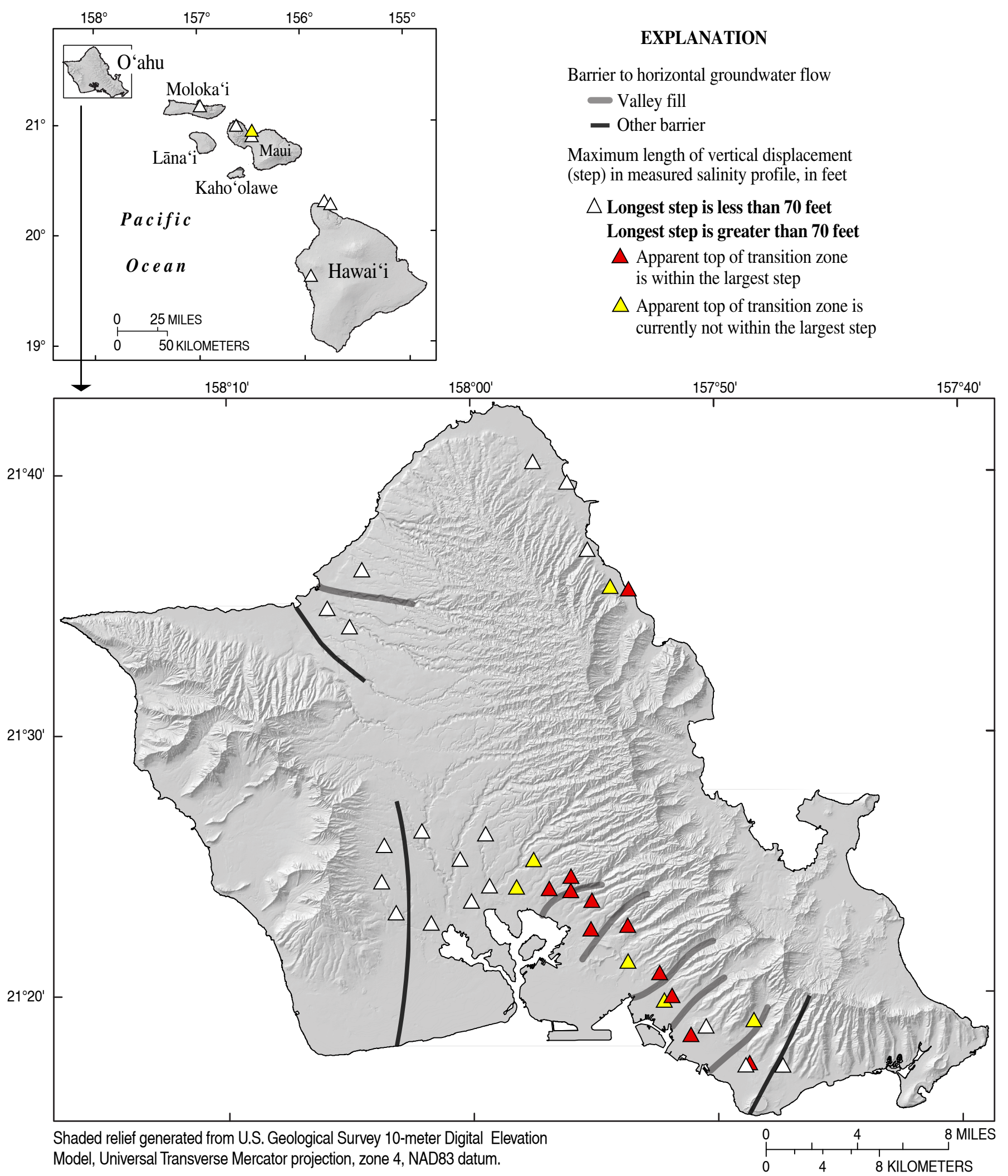

Figure 16. Maximum length of vertical step in measured salinity profiles from deep monitor wells in Hawaií. Steps longer than 70 feet may be related to nearby withdrawal or other factors, including regional drawdown in compartmentalized aquifers and natural hydraulic gradients at depth. The top of the transition zone is defined as having a specific conductance of 1,000 microsiemens per centimeter. The barriers to groundwater flow are modified from Oki (2005) and Rotzoll and El-Kadi (2007). 
Profiles from the Kalihi Shaft DMW indicate persistent vertical steps in salinity profiles that include the apparent top of the transition zone. Vertical steps in the Kalihi Shaft DMW are almost $600 \mathrm{ft}$ long (fig. 15C). The depth of outflow from Kalihi Shaft DMW coincides with the infiltration tunnel of Kalihi Shaft. The uniform specific conductance of the flow step increases over time, partly because withdrawal rates are consistently between 7 and $8.5 \mathrm{Mgal} / \mathrm{d}$ and for similar reasons to those stated for Kaamilo DMW above. A profile taken under no or low withdrawal conditions does not exist to verify whether the step disappears under those conditions. By collecting salinity profiles under consistent withdrawal rates, changes in specific conductance over time may be more readily detectable in wells that are affected by nearby or regional withdrawals.

Profiles from some wells indicate changes in specific conductance of the vertical flow step that are correlated significantly to daily mean withdrawal rates at nearby production wells. However, profiles from other wells may indicate changes in specific conductance of the flow step that are not correlated significantly to daily mean withdrawal rates (table 3 ). For these latter cases, the changes in specific conductance may be related to regional withdrawals or natural changes in the vertical hydraulic gradient. Vertical steps less than $70 \mathrm{ft}$ long that include the $1,000 \mu \mathrm{S} / \mathrm{cm}$ specific-conductance value exist in 13 DMWs (table 3). A vertical step less than $70 \mathrm{ft}$ may be related more to the presence of a massive lava flow than to high rates of borehole flow, because the step may not exceed the thickness of the massive flow. Vertical steps less than $70 \mathrm{ft}$ commonly are persistent, which is consistent with a step that is related mainly to the local geology. Nevertheless, monitoring the top of the transition zone in these wells may not be appropriate.
In general, wells with profiles having flow steps that exceed massive lava-flow thicknesses of $70 \mathrm{ft}$ and that include the $1,000-\mu \mathrm{S} / \mathrm{cm}$ specific-conductance value are concentrated from east Pearl Harbor to Honolulu (fig. 16). Additional wells with profiles having flow steps that exceed $70 \mathrm{ft}$ exist in the Punalu' $u$ area and near Waiehu on Maui. Although the longest vertical step in profiles from some wells may not include the $1,000 \mu \mathrm{S} / \mathrm{cm}$ specific-conductance value, the maximum specific conductance of the flow step may exceed $1,000 \mu \mathrm{S} / \mathrm{cm}$ in the future or the depth of that value is currently already included in shorter steps below the longest one. Because salinity profiles without steps are not available for many wells, it is difficult to determine where the $1,000-\mu \mathrm{S} / \mathrm{cm}$ depth is in the aquifer and how much the monitored apparent top of the transition zone in the well differs from the true location of the top of the transition zone in the aquifer.

Low-permeability valley fills, dike zones, and the caprock impede horizontal flow in aquifers in Honolulu and east Pearl Harbor. The locations of wells with profiles that have long vertical steps not directly related to changes in daily withdrawal rates coincide with the aforementioned area of aquifers with barriers to horizontal flow. Profiles from these wells may be affected by regional withdrawals in the compartmentalized aquifers and provide a poor estimate of the top of transition zone in the aquifer. Withdrawal from production wells more than $0.5 \mathrm{mi}$ from a monitor well may affect salinity profiles in the monitor well (for example, South Hālawa DMW and Newtown DMW), although not necessarily on a short-term, daily time scale. Profiles from a few monitor wells (Punchbowl DMW and Kaimukī HS DMW) in compartmentalized aquifers have short vertical steps. Low-permeability feeder dikes associated with a rejuvenated-stage volcanic vent (Punchbowl
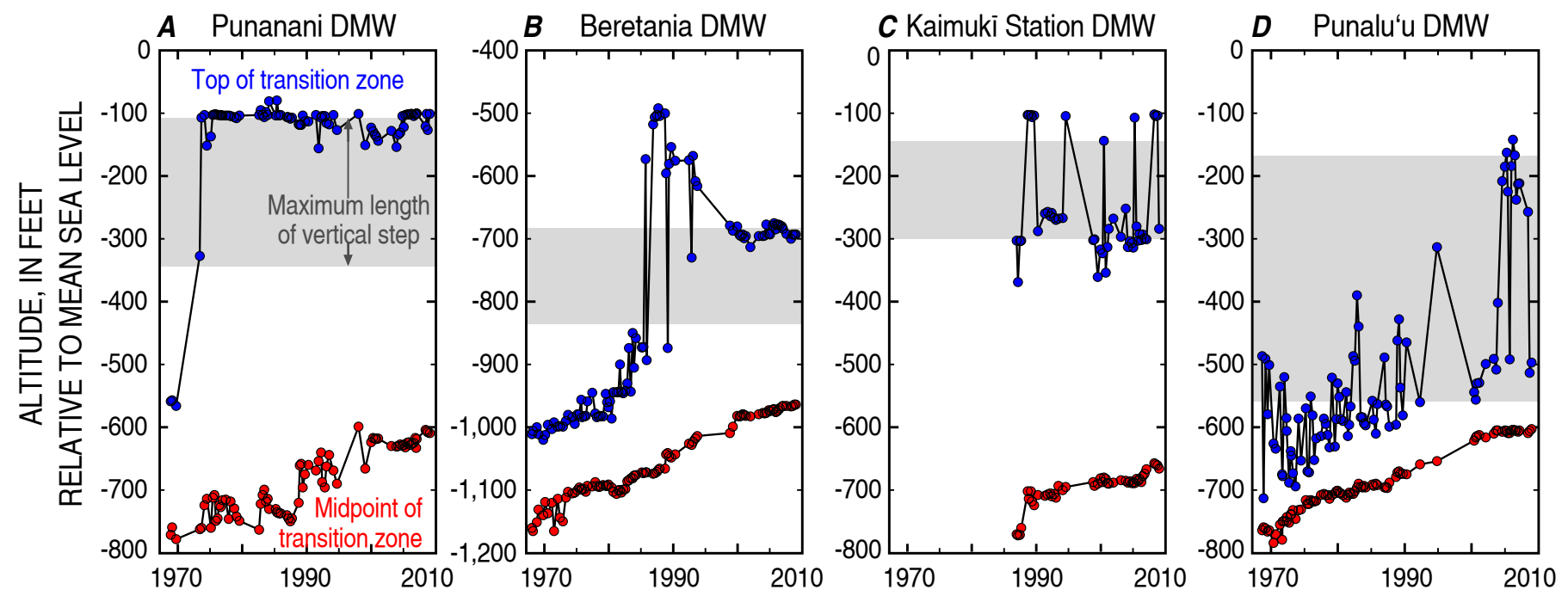

Figure 17. Changes from 1968 to 2009 in the depths of the apparent top and midpoint of the transition zone between fresh and saltwater measured in deep monitor wells, and longest vertical step (gray bands). A, Punanani DMW. B, Beretania DMW. C, Kaimukī Station DMW. D, Punalu‘u DMW. 
Crater) intrude the aquifer near the Punchbowl DMW, and these dikes may impede regional drawdown from extending to the monitor well. Vertical steps that include the $1,000 \mu \mathrm{S} / \mathrm{cm}$ specific-conductance value exist in profiles from Kaimukī HS DMW, although the maximum vertical extension of the steps is only $28 \mathrm{ft}$. Monitor wells located outside the compartmentalized aquifers of Honolulu and the east Pearl Harbor area and far from any major production wells generally have profiles with vertical steps of salinity less than $70 \mathrm{ft}$ or that are largely unaffected by changes in withdrawal rates.

Time series of the measured depths of the apparent top and midpoint of the transition zone illustrate the potential problem of misinterpreting aquifer water-quality changes from profiles (fig. 17). The longest vertical step in salinity profiles (table 3 ) is shown as a gray box on figure 17. The production wells at Punanani were not completed and used before 1971. Three of the six production wells are slotted between -70 and $-220 \mathrm{ft}$, and the others are slotted between $-150 \mathrm{ft}$ and $-310 \mathrm{ft}$. After 1972, groundwater was withdrawn from the Punanani production wells continuously (see fig. 21A). The effect of the vertical step is evident when the measured depth of the apparent top of the transition zone changes from $-560 \mathrm{ft}$ to $-100 \mathrm{ft}$ within 4 years from 1969 to 1973 (fig. 17A). The apparent midpoint depth rose several feet per year, whereas the depth of the apparent top of the transition zone rose rapidly after 1972 and then fluctuated between -80 and $-156 \mathrm{ft}$, depending on whether the shallow or the deep production wells were pumped. The apparent top of the transition zone in the Beretania DMW rose slowly until the mid 1980s, because the step in the profiles did not include the $1,000-\mu \mathrm{S} / \mathrm{cm}$ specific-conductance value before then. In about 1985, the apparent top of the transition zone rose rapidly from $-850 \mathrm{ft}$ to $-500 \mathrm{ft}$ (fig. $17 B$ ). Since 1998 , the depth of the apparent top of the transition zone has remained nearly stationary at about $-680 \mathrm{ft}$, although the apparent midpoint has risen continuously over the past 40 years. Both these examples show that the measured depth of the apparent top of the transition zone may shift rapidly to a shallower depth when the horizontal part of the step includes the $1,000-\mu \mathrm{S} / \mathrm{cm}$ specific-conductance value. Because of upward borehole flow, monitoring the depth of the apparent top of the transition zone in these monitor wells may not accurately reflect conditions in the aquifer, because it underestimates the $1,000-\mu \mathrm{S} / \mathrm{cm}$ specificconductance depth in the aquifer.

In the next two examples (figs. $17 C, D$ ), nearby withdrawals affect borehole flow and the depth of the apparent top of the transition zone (see also fig. 14). The depth of the apparent top of the transition zone $(1,000-\mu \mathrm{S} / \mathrm{cm}$ specific conductance) in Kaimukī Station DMW is near -260 to $-375 \mathrm{ft}$ when nearby withdrawal from Kaimukī Station is less than $4 \mathrm{Mgal} / \mathrm{d}$ and near -100 to $-150 \mathrm{ft}$ when withdrawal rates are higher (fig $17 C$ ). Thus, when nearby groundwater withdrawals are high, monitoring salinity profiles from this DMW underestimates the top of transition zone. In Punalu'u DMW, nearby withdrawal induces downward flow in the monitor well, which counteracts the natural upward flow associated with the discharge zone of the aquifer. Under low withdrawal rates, the apparent top of the transition zone is near a depth of $-170 \mathrm{ft}$, whereas when withdrawal rates are high it is below $-500 \mathrm{ft}$ (fig 17D). The top of the transition zone in the aquifer is most likely between these extremes, but salinity profiles underestimate or overestimate the measured depth, depending on the nearby withdrawal rates. Both examples show a progressively shallower apparent midpoint depth over time but large fluctuations of the depth of the apparent top of the transition zone because of borehole flow induced by nearby groundwater withdrawal. Because of upward and downward borehole flow (fig. 6), monitoring the depth of the apparent top of the transition zone in these monitor wells also may not accurately reflect conditions in the aquifer.

\section{Apparent Midpoint of Transition Zone}

\section{Steps at the Apparent Midpoint}

Vertical steps at the apparent midpoint of the transition zone (defined as the level at which specific conductance equals $25,000 \mu \mathrm{S} / \mathrm{cm}$ ) occur in several DMWs. The longest vertical step of $120 \mathrm{ft}$ at the apparent midpoint occurs in Waimalu DMW. Steps at the apparent midpoint in other monitor wells range in length from a few tens of feet in Jonathan Springs DMW, Newtown DMW, and Poliwai DMW to $65 \mathrm{ft}$ in Waimano DMW. However, all steps are persistent over time because they are evident in all available profiles at the same interval. The steps may be related to the presence of massive lava flows rather than to high rates of borehole flow. Nevertheless, the measured apparent midpoint of the transition zone in these boreholes may consistently underestimate the midpoint depth in the aquifer.

\section{Relation Between Daily Withdrawal Rates and Apparent Midpoint of Transition Zone}

The depth of the apparent midpoint of the transition zone between freshwater and saltwater in salinity profiles was compared to daily mean withdrawal rates from the largest production wells near the DMW. The rise of the apparent midpoint depth between 1999 and 2009 (Rotzoll and others, 2010) was removed, assuming a linear trend that was determined using the nonparametric Mann-Kendall test (Helsel and Hirsch, 1992). Although it is recognized that the movement of the transition zone is transient, available data of the apparent midpoint depth show almost no response to seasonal or interannual recharge and discharge variations in the past 10 years (fig. 17). Thus, using a simplified linear trend was justified.

The depth of the apparent midpoint of the transition zone and daily mean withdrawal rate generally do not show a statistically significant correlation, indicated by $p$ values much larger than 0.1 (table 3). The effects of nearby withdrawals apparently are more pronounced in upper levels of the monitor wells. However, two cases show a statistically significant relation ( $p$ values $<0.03$ ) between withdrawal rate and depth of the apparent midpoint. The first case is Punanani DMW, with 
a correlation coefficient of 0.55 . The apparent midpoint depth in Punanani DMW shows the largest fluctuations (compared to apparent midpoint depths that rise more smoothly in other wells; see fig. 17A), which may indicate that withdrawal also affects the apparent midpoint depth. The slope of the regression equation between depth of the apparent midpoint and daily mean withdrawal rate is $1.5 \mathrm{ft} / \mathrm{Mgal} / \mathrm{d}$. Considering that withdrawal rates can be as high as $16 \mathrm{Mgal} / \mathrm{d}$, the apparent midpoint could theoretically be displaced more than $22 \mathrm{ft}$ compared to zero-withdrawal conditions. However, comparing two salinity profiles under nonpumping and pumping conditions (fig 12A), the apparent midpoint at zero withdrawal is only $4 \mathrm{ft}$ deeper compared to the apparent midpoint under $12 \mathrm{Mgal} / \mathrm{d}$ withdrawal (not $18 \mathrm{ft}$, as indicated by the slope of the regression). The second case is Kaamilo DMW, with a correlation coefficient of 0.64 and a slope of the regression between apparent midpoint depth and nearby withdrawals of $0.65 \mathrm{ft} / \mathrm{Mgal} / \mathrm{d}$. This slope translates into an $8.5-\mathrm{ft}$ displacement under high withdrawal conditions of $13 \mathrm{Mgal} / \mathrm{d}$ at the nearby wellfield. The effects of withdrawals on the apparent midpoint depth are reasonable, given the very large flow step extending over $686 \mathrm{ft}$. The bottom of the step and recent apparent midpoint depths are only $85 \mathrm{ft}$ apart, and nearby withdrawal may plausibly affect more than the apparent top of transition zone. The relation between apparent midpoint depth and withdrawal rate can be verified by installing a CTD sensor near the depth of the apparent midpoint and monitoring salinity under variable withdrawal rates. For all other monitor wells, no significant relation exists between daily mean withdrawal rate from nearby production wells and apparent midpoint depth.

\section{OCEAN TIDE, IN FEET RELATIVE TO MEAN SEA LEVEL}

\section{BAROMETRIC PRESSURE, IN FEET OF WATER}

BERETANIA PUMPAGE, IN MILLION GALLONS PER DAY

\section{WATER LEVEL, IN FEET RELATIVE TO MEAN} SEA LEVEL

SPECIFIC
CONDUCTANCE,
IN MILLISIEMENS
PER CENTIMETER
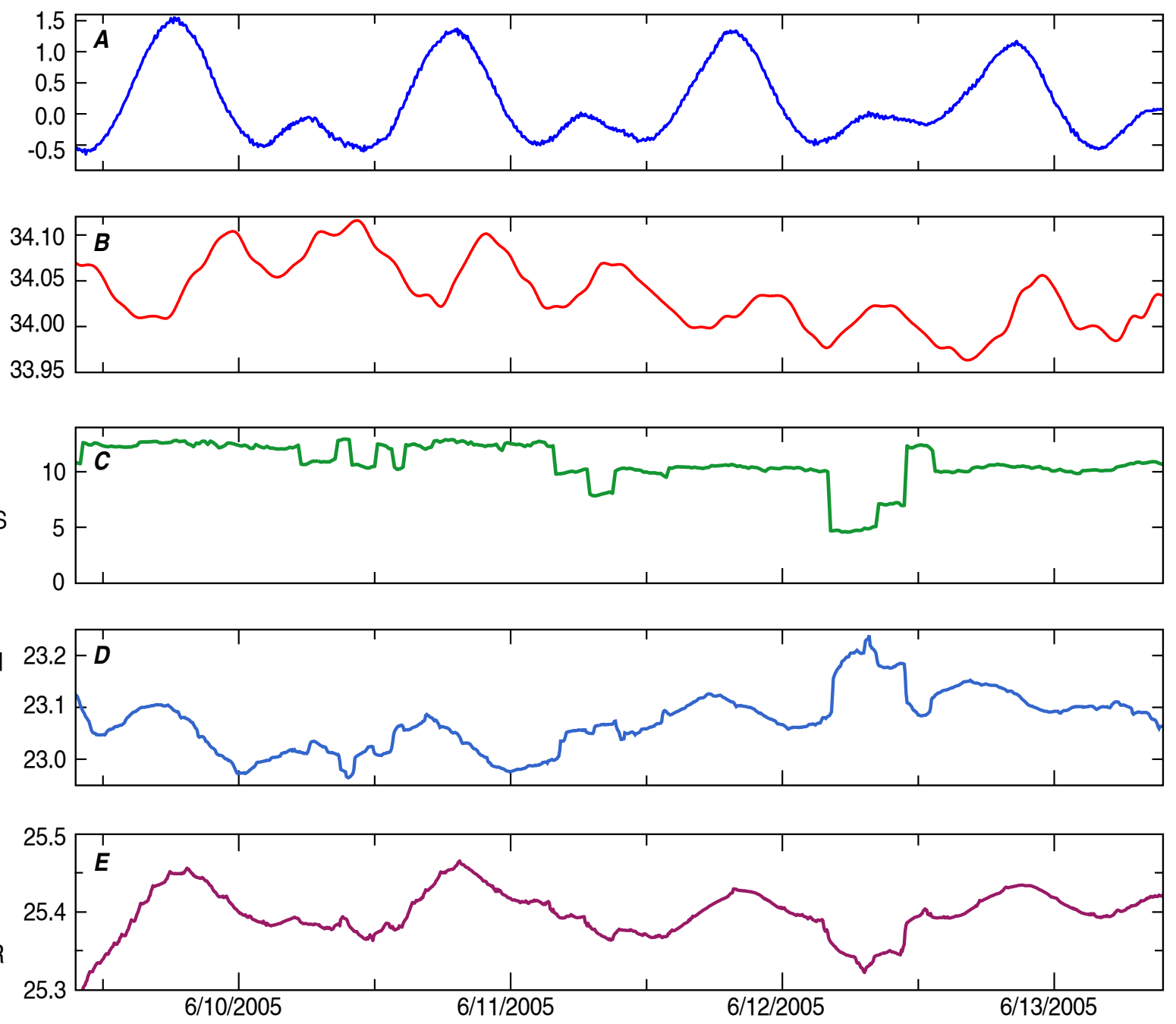

Figure 18. Influence of natural and human-induced stresses on the salinity profile in a deep monitor well. $A$, Honolulu ocean tide. $B$, Honolulu Airport barometric-pressure oscillations. $C$, Groundwater withdrawal rates at Beretania pumping center. $D$, Water level in Beretania Deep Monitor Well (DMW). E, Specific conductance near the apparent midpoint of the transition zone in Beretania DMW. 


\section{Case Study: Beretania DMW}

The following case study illustrates small effects of nearby withdrawals in the Beretania DMW near the apparent midpoint depth of the transition zone. Beretania DMW is located 3,600 ft inland in the $\mathrm{Nu}$ 'uanu area (fig. 1), $270 \mathrm{ft}$ from the Beretania production wells. A CTD data logger installed in the DMW near the altitude of the apparent midpoint at $-982 \mathrm{ft}$ measured and recorded fluid specific conductance, temperature, and water level every second for more than 4.5 days starting June 10, 2005. Ocean tides, barometric pressure, and nearby withdrawals affect water levels and water quality in the DMW (fig. 18). The ocean tide was recorded at the Honolulu Harbor tide gage, and the atmospheric pressure was monitored at the Honolulu airport. The head fluctuations in Beretania DMW indicate a tidal efficiency (ratio of tidal amplitude in well to tidal amplitude in ocean) of only 3.6 percent and a tidal lag of 0.5 hour. The amplitude of the tidal response is greatly attenuated compared to the response in other wells in Hawai' $i$ at comparable distances inland (Oki, 1997; Rotzoll and others, 2008), mainly because of the thick low-permeability sedimentary coastal caprock confining the highly permeable basalt aquifer (Li and others, 2007; Rotzoll and others, 2008). Barometric efficiency (ratio of barometric-pressure amplitude in well to atmospheric-pressure amplitude), as indicated by the response

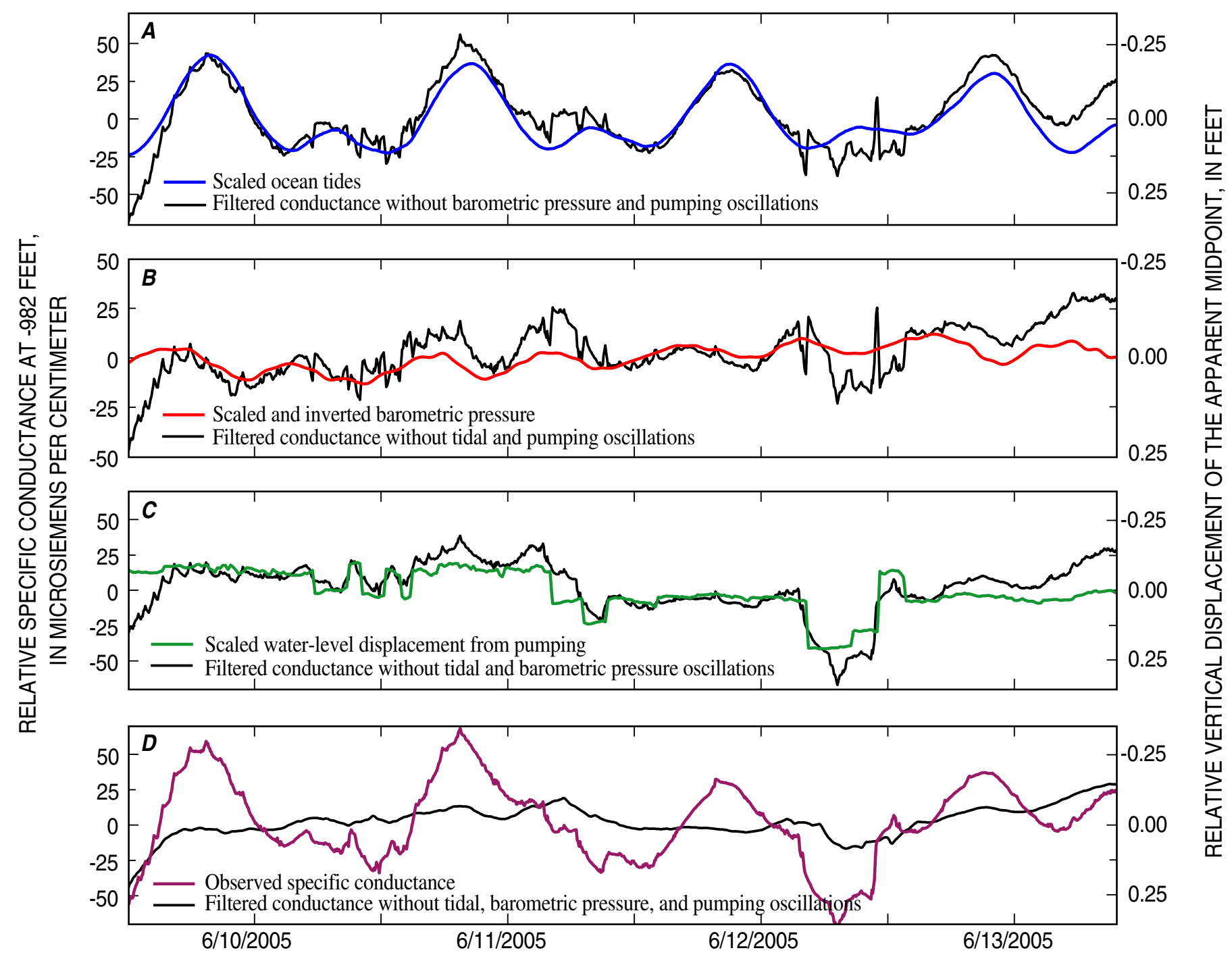

Figure 19. Observed and estimated specific-conductance changes and relative vertical displacement of the apparent midpoint of the transition zone in Beretania DMW attributed to $(A)$ ocean tides, $(B)$ barometricpressure oscillations, $(C)$ nearby groundwater withdrawal, and $(D)$ all three stresses combined. 
of the water level in the DMW, is 66 percent, and drawdown in the monitor well did not exceed $0.25 \mathrm{ft}$ (during the period of measurement) for a withdrawal rate of $12.3 \mathrm{Mgal} / \mathrm{d}$ at the Beretania production wells.

Each of the three stresses-ocean tides, barometric pressure, and nearby groundwater withdrawals-is isolated by regressing the two other stresses onto the observed specific-conductance time series, including the time lag for each stress by cross correlation, and subtracting both time series from the observed one. The filtering procedure is outlined as follows (see, for example Rotzoll and El-Kadi, 2008): (1) estimate the time lag of specific conductance to each stress (table 4) and shift the stress time series accordingly, (2) subtract the mean value of each stress from each stress time series, (3) estimate the scaling coefficient of each stress by linear regression of the stress onto the specificconductance time series and multiply each stress time series by its coefficient, and (4) subtract the time-lag-corrected, zero mean, and scaled stress time series from the observed specific-conductance time series. The result is a filtered time series that shows the computed specific-conductance variations attributed to each of the three stresses (fig. 19). The filtered time series contains small-scale fluctuations caused by incomplete accounting of all factors that may affect the observed variations in specific conductance. The removal of withdrawal effects assumes instantaneous response with change in discharge and does not account for the transient response of drawdown and recovery. Furthermore, the removal of specific-conductance variations caused by barometric pressure could be improved by accounting for air flow

Table 4. Effect of stresses from ocean tides, barometric pressure, and nearby groundwater withdrawals on specific conductance recorded at the apparent midpoint of the transition zone in Beretania Deep Monitor Well.

[Mgal/d, million gallons per day; $\mu \mathrm{S} / \mathrm{cm}$, microsiemens per centimeter; $\mathrm{ft}$, feet]

\begin{tabular}{lccc}
\hline Stress & $\begin{array}{c}\text { Time lag } \\
\text { of specific } \\
\text { conductance } \\
\text { to stress, in } \\
\text { hours }\end{array}$ & $\begin{array}{c}\text { Specific } \\
\text { conductance } \\
\text { change at } \\
\text { midpoint of } \\
\text { transition } \\
\text { zone, in } \mathbf{\mu S / c m}\end{array}$ & $\begin{array}{c}\text { Vertical } \\
\text { displacement } \\
\text { of midpoint of } \\
\text { transition zone } \\
\text { in response to } \\
\text { stress, in ft }\end{array}$ \\
\hline $\begin{array}{l}\text { Ocean tide } \\
\text { Barometric } \\
\text { pressure } \\
\text { Withdrawal at }\end{array}$ & 1.5 & 70 & 0.36 \\
$\begin{array}{l}\text { 4.7 Mgal/d } \\
\text { Withdrawal at }\end{array}$ & 0.0 & 30 & 0.15 \\
$7.1 \mathrm{Mgal} / \mathrm{d}$ & 0.5 & 20 & 0.10 \\
$\begin{array}{l}\text { Withdrawal at } \\
10.2 \mathrm{Mgal} / \mathrm{d}\end{array}$ & 0.5 & 41 & 0.21 \\
$\begin{array}{l}\text { Withdrawal at } \\
12.3 \mathrm{Mgal} / \mathrm{d}\end{array}$ & 0.5 & 105 & 0.42 \\
\hline
\end{tabular}

in the unsaturated zone and vertical flow in the aquifer (Oki, 1997; Spane, 2002).

Other stresses that are not considered here may influence the water level and specific conductance at the apparent midpoint depth. However, for identifying the general effects of the three main stresses, the technique used in this study is satisfactory. If the effects of all stresses are completely removed, the filtered time series should be a horizontal line (fig. 19D). Because the filtering method did not completely remove the effects of all stresses, the filtered time series is not a horizontal line and represents the residual or part of the specific-conductance variations unexplained by or improperly attributed to tidal, barometric-pressure, and nearby groundwater-withdrawal variations. Nevertheless, variations of specific conductance at the apparent midpoint depth in the profile caused by the three stresses can be evaluated.

The stationary data logger at the apparent midpoint of the transition zone reveals the effects of ocean tides, barometric pressure, and nearby withdrawals. Table 4 lists the maximum variation of specific conductance caused by the individual stresses. The specific-conductance changes are converted to vertical displacements by using the slope of specificconductance profiles at the apparent midpoint. The average slope of three salinity profiles in Beretania DMW from 2005 at the apparent midpoint (between 23,000 and 27,000 $\mu \mathrm{S} / \mathrm{cm}$ ) is $0.0051 \mathrm{ft} / \mu \mathrm{S} / \mathrm{cm}$. The vertical displacement caused by any single stress does not exceed $0.5 \mathrm{ft}$. For an extreme scenario of coinciding high tides, low barometric pressure, and withdrawal of $12.3 \mathrm{Mgal} / \mathrm{d}$, the vertical displacement would be about 1 $\mathrm{ft}$. Therefore, these stresses cause only small specific-conductance fluctuations near the apparent midpoint of the profile in Beretania DMW. Although this response may be relevant only to the Beretania DMW, a similar observation was made in Kaimukī Station DMW. Paillet and others (2002) compared fluid-column resistivity profiles taken on consecutive days in 2001 under different nearby withdrawal rates of 3.8 and 7 $\mathrm{Mgal} / \mathrm{d}$. The apparent midpoint was located near $-690 \mathrm{ft}$ in both profiles, although the upper part of the profiles (above $-470 \mathrm{ft}$ ) changed in response to nearby withdrawals (fig. $9 A$ ). This indicates that nearby withdrawals (70 ft distant) may mainly affect the upper part of the salinity profiles from the Kaimukī Station DMW.

\section{Effects of Withdrawal on Water Quality}

\section{Deep Monitor Wells Acting as Brackish-Water Conduits}

Deep wells were drilled close to production wells to monitor upconing caused by the pumped wellfield. However, the DMW may provide a conduit for brackish water to flow upwards into parts of the aquifer from which production wells withdraw groundwater (fig. 20). Drawdown near a pumped well propagates horizontally more readily than vertically in the anisotropic aquifers in Hawai' $i$. Conceptually, therefore, 
drawdown near the Punanani production wells extends farther in a horizontal direction than a vertical direction because of the aquifer anisotropy. Water from deeper parts of the aquifer moves upward inside the borehole and exits the well at depths corresponding to the slotted interval of the production wells. Water flows vertically with less resistance inside an open borehole than through the layered basalt aquifer. This is evident by the observed upward flow (fig. $9 B$ ) and the steps in the specific-conductance and temperature profiles between -140 and $-450 \mathrm{ft}$ (fig. 11B).

Because of upward borehole flow in a DMW, the quality of water discharged at nearby production wells may be impaired by brackish water from deeper parts of the aquifer. The Punanani DMW is located within the compound of the Punanani production wells (fig. 3). Water samples from individual production wells indicate higher chloride concentrations and specific-conductance values from wells closest to the monitor well, such as P1 and P2 (fig. 21). Wells P1 and P2 are slotted between $-150 \mathrm{ft}$ and $-310 \mathrm{ft}$, deeper than the slotted interval of P3, P4, and P5. The chloride concentrations of water samples from $\mathrm{P} 1$ are higher than those from P2 (fig. 21A), although P2 is located closer to the monitor well. P1 may withdraw higher salinity water from deeper in the aquifer than P2. P6 is slotted at the same interval as P1 and P2 but is farther from the monitor well. Water from P6 has the lowest chloride and specific-conductance values, indicating that water quality in P6 may not be affected much by upward flow of brackish water in the DMW.

Because water quality from P1 did not meet the EPA standard for drinking water, $\mathrm{P} 1$ has been used rarely since May 2001. Overall withdrawal rates at the wellfield declined

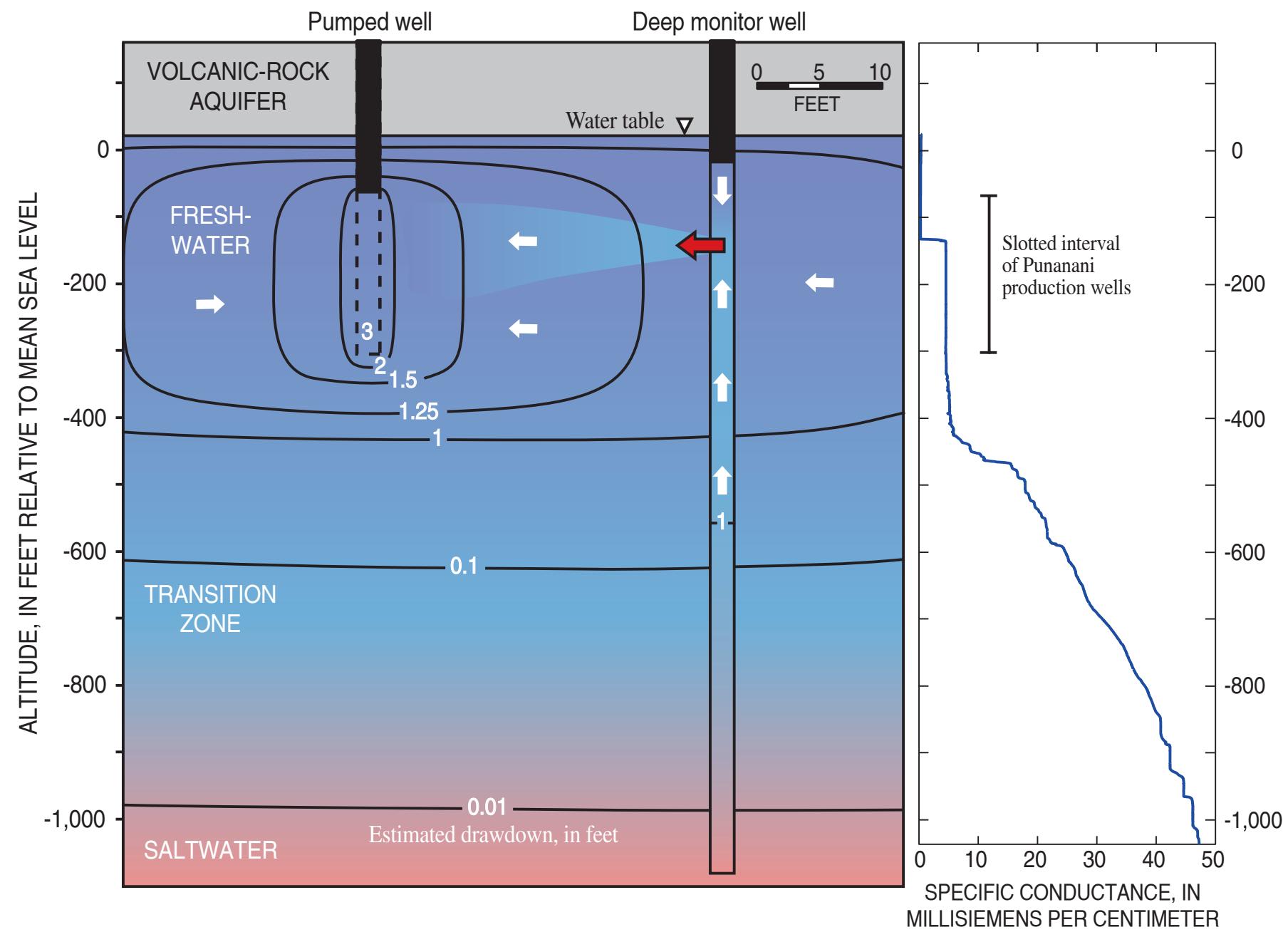

Figure 20. Conceptual cross section between production well and nearby monitor well and specific-conductance profile in Punanani DMW. The contours represent conceptual drawdown in an anisotropic basalt aquifer caused by groundwater withdrawals that induce upward flow of brackish water in the upper part of the monitor well. The arrows are principal pathways of groundwater flowing towards the production well. 
from $14 \mathrm{Mgal} / \mathrm{d}$ to $10 \mathrm{Mgal} / \mathrm{d}$ between 2001 and 2007, resulting in a decrease of chloride concentrations in water from all remaining wells except $\mathrm{P} 4$. When $\mathrm{P} 2$ is pumped, the depth of outflow from the upward-flow step in the monitor well is between -125 and $-150 \mathrm{ft}$. When P2 is not pumped, the depth of outflow is shallower at $-100 \mathrm{ft}$. In addition, the conductance of water from $\mathrm{P} 4$ increases when $\mathrm{P} 2$ is not in use. All specific-conductance values from $\mathrm{P} 4$ that are greater than $400 \mu \mathrm{S} / \mathrm{cm}$ were sampled on days that $\mathrm{P} 2$ was not sampled and therefore not pumped (D. Wong, Honolulu Board of Water Supply, written commun., 2008) (fig. 21B). This may indicate that brackish water flowing out of the monitor well, which usually flows to P2, is extracted by $\mathrm{P} 4$. Water from the production wells downgradient of the monitor well and closer to the ocean has higher salinity (fig. $21 C$ ). Another source of brackish water in the Pearl
Harbor aquifer is return water from irrigation (Eyre, 1983, 1987). The effects of nutrient-rich irrigation water on water quality in the aquifer generally are reduced after several years (Eyre, 1983), and because sugarcane agriculture upgradient from Punanani ceased in the mid-1970s (Oki, 2005), irrigation return water cannot explain the recent elevated salinity in the aquifer near Punanani.

Water sampled from wells near the South Hālawa DMW also has elevated salinities that may be related to borehole flow in the DMW. Water samples collected in two Red Hill monitor wells in 2005 (fig. 3) at the same altitude as South Hālawa DMW have mean specific-conductance values of $744 \mu \mathrm{S} / \mathrm{cm}$ and $701 \mu \mathrm{S} / \mathrm{cm}$. For comparison, water from a monitor well upgradient of South Hālawa DMW had a specific conductance of $461 \mu \mathrm{S} / \mathrm{cm}$, and water from a well downgradient had a specific conductance of $561 \mu \mathrm{S} / \mathrm{cm}$ (TEC Inc., 2007). Brackish
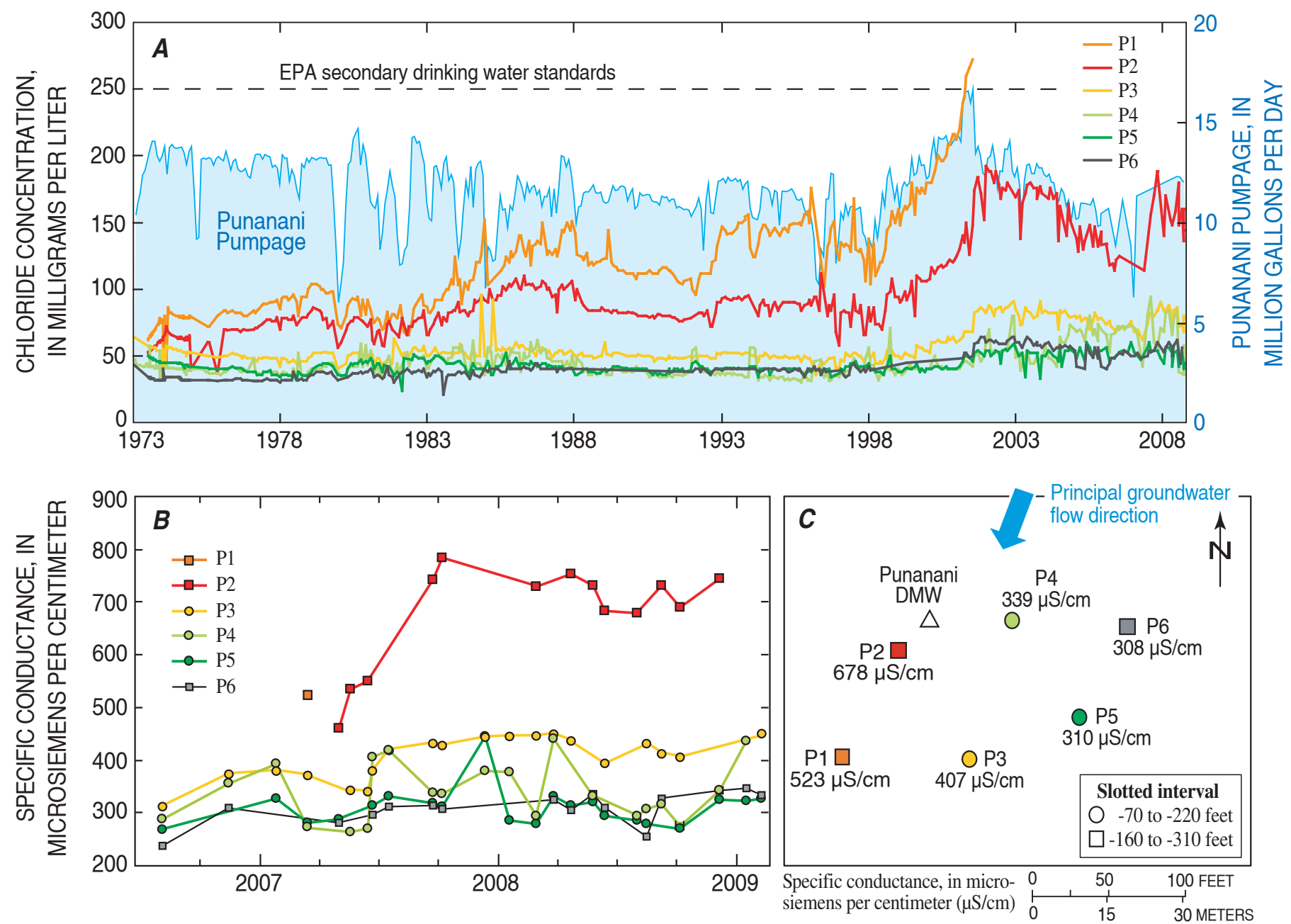

Figure 21. Salinity of water in Punanani production wells. A, Time series of chloride concentration of water samples and Punanani pumping rates. $B$, Time series of specific conductance of water samples. $C$, Map view of shallow (circles) and deep (squares) slotted production wells adjacent to Punanani DMW and mean specific conductance of samples between August 2006 and February 2009. 
water transported through the DMW may be the source for the elevated salinities in the monitor wells close to the DMW.

\section{Mass Balance}

A simple mass balance based on proportional mixing is used to estimate the contribution of brackish water from Punanani monitor well to the production wells, according to the following relation (Izbicki and others, 1999; Sukop, 2000):

$$
C_{\text {total }}=\frac{C_{A q} Q_{A q}+C_{M W} Q_{M W}}{Q_{\text {total }}}
$$

where $C_{\text {total }}$ and $Q_{\text {total }}$ are the solute concentration of water that was withdrawn by the production well and total rate of withdrawal by the production well, $C_{A q}$ and $Q_{A q}$ are the background concentration in the surrounding aquifer and the part of total withdrawal by the production well contributed by the surrounding aquifer, and $C_{M W}$ and $Q_{M W}$ are the solute concentration of water from the monitor well and the part of total withdrawal by the production well contributed by the monitor well, respectively. The calculation assumes conservative mixing and conservation of mass.

On June 10, 2008, four production wells (P2, P3, P5, and P6, fig. 21C) were being pumped while Punanani DMW was logged. The capacity of each pump is $2.7 \mathrm{Mgal} / \mathrm{d}$. The ambient background specific-conductance level in the Punanani area is $300 \mu \mathrm{S} / \mathrm{cm}$, which is taken from the specific-conductance profile before withdrawals began in 1968. On June 10, 2008, the specific conductance of water within the interval of the upward-flow step in the monitor well was $4,100 \mu \mathrm{S} / \mathrm{cm}$, and in P2 it was $684 \mu \mathrm{S} / \mathrm{cm}$. Flow measurements from 2001 indicate upward flow in the monitor well that did not exceed $0.053 \mathrm{Mgal} / \mathrm{d}$. Using equation 3 and assuming all water exiting the monitor well was extracted by the closest production well, the elevated specific conductance in the monitor well would only raise the specific conductance of the pumped water from 300 to $376 \mu \mathrm{S} / \mathrm{cm}$. To account for the observed $684 \mu \mathrm{S} / \mathrm{cm}$ in $\mathrm{P} 2$, the contribution from the monitor well must be 10 percent of the total pumped water and the necessary upflow in the monitor well would have to be five times higher $(0.27 \mathrm{Mgal} / \mathrm{d})$ than observed. Because other production wells also may capture water from the monitor well and not all water exiting the monitor well is captured by the production wells, the required flow is even greater.

Upward borehole flow in the DMW may not fully account for the enhanced salinity in the nearby production wells from mass-balance considerations because (1) available flow measurements may underestimate the flow in the monitor well, (2) upconing of the transition zone under the production wells may contribute to elevated salinity in the production wells, and (3) additional salinity may be contributed from wellbore flow in unused production wells of the wellfield. Because water from the production wells closest to the monitor well have the highest specific-conductance values and water from the farthest production well (slotted at the same interval) has specific-conductance values as low as the background salinity, brackish water pumped by some wells may originate from the monitor well. However, upconing beneath the production wells and borehole flow in the unused production wells also may contribute to enhanced salinity of water pumped by some wells.

\section{Ground water Management Implications}

Borehole flow affects some DMWs, but may not affect all wells in the same way. Vertical steps in salinity profiles are indicative of borehole flow (fig. 6), and the longest steps occur in monitor wells located in south-central O'ahu (fig. 8), which coincides with the most heavily developed part of the aquifer, and in monitor wells located close to production wells or within compartmentalized aquifers. Hence, in many DMWs in the Honolulu and east Pearl Harbor areas, the salinity profiles provide poor estimates of the top of the transition zone in the aquifer (fig. 16). Withdrawals may cause a rise of the apparent top of the transition zone of several hundred feet in some wells (table 3), which is not representative of the top of the transition zone in the aquifer. Monitoring salinity profiles in these wells can be improved by logging under consistent withdrawal conditions or deploying CTD sensors at multiple depths with variable nearby groundwater withdrawals to estimate the direct influence of pumping on measured water quality near the apparent top and midpoint

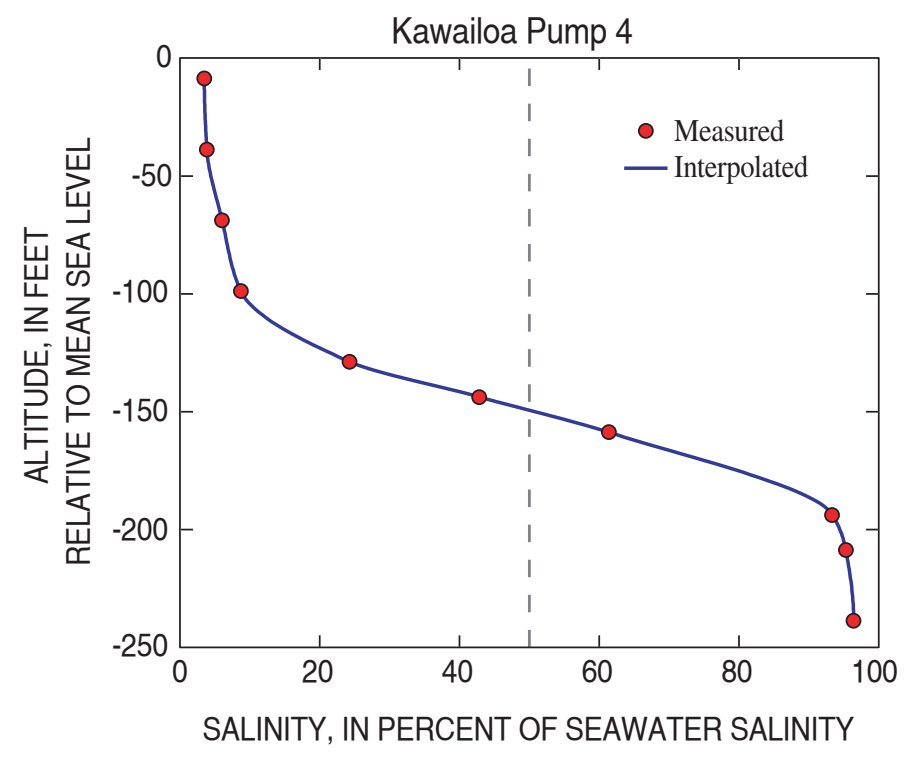

Figure 22. Salinity of water from point piezometers through the freshwater-saltwater transition zone in Kawailoa Pump 4, northern O'ahu, Hawai'i, measured on March 12, 1956 (unpub. data, USGS data files). 
of the transition zone. In contrast to the apparent top of the transition zone, the effects of nearby withdrawals may be inconsequential at the measured midpoint. Monitoring the apparent midpoint depth as a proxy for freshwaterlens thickness therefore may be more useful for evaluating movement of the transition zone and shrinking or expanding of the freshwater lens.

Quality assurance and quality control are important to enable meaningful comparisons of salinity profiles from successively logged monitor wells, particularly for data compiled from different sources. Piezometers installed at different depths will provide the best information on aquifer salinity, because they are not affected by borehole flow. Piezometers are open to the aquifer over short depth intervals and water samples collected from the piezometer tube represent water from the aquifer at the slotted interval. Generally, several piezometers at different depths facilitate monitoring the freshwater lens. Ten piezometers (plastic tubes) were installed through the transition zone near Kawailoa Pump 4 of northern $\mathrm{O}$ 'ahu (fig. 3). Water quality at discrete depths was used to define a profile (unpub. data, USGS data files), and the apparent midpoint of the transition zone between freshwater and saltwater was determined by interpolation (fig. 22). The apparent midpoint is estimated to be at $-150 \mathrm{ft}$ using a piecewise cubic Hermite interpolating polynomial (Fritsch and Carlson, 1980). The water level was $3.8 \mathrm{ft}$ and the theoretical midpoint according to the Ghyben-Herzberg relation should be at $-152 \mathrm{ft}$, which agrees with the observed midpoint. Repeated salinity measurements in the piezometers allow tracking the movement of the transition zone over time, without any borehole-flow effects.

Using misrepresentative indicators of the position of the transition zone between freshwater and saltwater has implications for groundwater management. Most DMWs that are affected by borehole flow have vertical steps in measured salinity profiles that include the apparent top of the transition zone. In these cases, the indicators, if followed, could lead to overly conservative groundwater-management decisions because the top of the transition zone is deeper in the aquifer than measured in the DMW - a thicker freshwater lens exists in the aquifer than indicated by the salinity profile. One well (Punalu'u DMW) is partly affected by downward borehole flow. In this case, misinterpretations are consequential for groundwater management, because a thinner freshwater lens exists in the aquifer than indicated by the salinity profile. Although the depth of the apparent top of the transition zone from DMWs may not accurately reflect the top of the transition zone in the aquifer, monitoring is still valuable because the measured apparent midpoint of the transition zone may provide a useful indicator of the freshwater-lens thickness.

It would be useful to identify deep zones in existing boreholes that contribute salinity to the freshwater resource and target these zones for sealing. The shallower parts of these boreholes may be used for future production. This could be an economical way to reduce contamination by brackish water and improve production.

\section{Summary and Conclusions}

Vertical flow in a deep monitor well (DMW) may cause measured salinity profiles to reflect inaccurately the water quality in the adjacent aquifer. Such borehole flow is caused by natural or anthropogenically induced head gradients. Indicators of borehole flow include differences in salinity and temperature between adjacent shallow and deep monitor wells, flow measurements, and stepwise increases of salinity and temperature with depth. The vertical part of steps may represent depth intervals over which water is transported vertically in a well, and salinity and temperature of the water remain nearly uniform over that section. Because of borehole flow and the vertical heterogeneity and anisotropy of layered Hawaiian basalt aquifers, many steps of different magnitude occur in salinity profiles for different reasons. Persistent steps that are shorter than $70 \mathrm{ft}$ may be related more to the presence of massive low-permeability layers and less to substantial borehole flow. Vertical steps longer than $70 \mathrm{ft}$, which exceeds the typical thickness of dense lava flows, are indicative of borehole flow. The longest vertical step in salinity in one borehole is $644 \mathrm{ft}$. Substantial borehole flow is induced locally by nearby groundwater withdrawals or through effects of regional withdrawals within compartmentalized aquifers near Honolulu and the east Pearl Harbor area, and it may affect long sections of a salinity profile that could result in underestimation of the freshwater storage in the aquifer by several hundred feet.

The effect of groundwater withdrawal on measured salinity is commonly observed near the apparent top of the transition zone (taken to be at $1,000 \mu \mathrm{S} / \mathrm{cm}$ specific conductance). Nearby groundwater withdrawal may induce mostly upward borehole flow in DMWs and cause an increase in specific conductance in the upper part of the profile, which commonly is positively correlated with increases in withdrawal rates. The vertical steps that are evident in salinity profiles are consistent with both steps in temperature profiles and flow measurements in monitor wells near production wells. The depth of the apparent top of the transition zone in a DMW may differ from the depth of the top of the transition zone in the aquifer by several hundred feet. Most of the monitor wells with profiles having vertical steps that include the apparent top of the transition zone are located in the Honolulu and east Pearl Harbor areas. No significant correlation exists between the proximity of monitor wells to production wells and the length of vertical steps of salinity in profiles. However, borehole flow in monitor wells near production wells commonly is affected by daily variations in withdrawals. Profiles from monitor wells located farther from production wells within compartmentalized aquifers indicate that changes in specific conductance may be controlled by regional drawdown. DMWs located in compartmentalized 
aquifers or near large groundwater withdrawals may provide a poor estimate of the top of transition zone. In contrast, the apparent midpoint of the transition zone $(25,000 \mu \mathrm{S} / \mathrm{cm}$ specific conductance) in DMWs is less affected by daily variations in nearby withdrawal rates. Water quality measured for several days near the apparent midpoint in one monitor well indicated inconsequential depth displacements of less than $1 \mathrm{ft}$ in response to barometric pressure and tidal fluctuations and to withdrawal from the nearby wellfield. Hence, the apparent midpoint depth may be more useful than the apparent top of transition zone to monitor changes in freshwater-lens thickness.

Production wells that withdraw water with elevated chloride concentrations and specific-conductance values and that are near a DMW may be affected by upward flow of brackish water within the monitor well. A DMW may act as a conduit that transports brackish water from deeper to shallower zones in an aquifer, which may impair the water quality in nearby production wells. A simple mass-balance computation associated with brackish water upflow in Punanani DMW could not account for the entire increase in salinity in pumped water relative to background concentrations. Additional salinity may be contributed from upconing beneath production wells and potential borehole flow in unused production wells of the wellfield. The longest vertical steps in salinity occur in profiles from monitor wells located in south-central $\mathrm{O}^{`} \mathrm{ahu}$, which coincides with the most heavily developed part of the aquifer, near production wells, and within compartmentalized aquifers.

Piezometers at different depths can provide the best information on aquifer salinity because they are not affected by borehole flow, although they are a more expensive alternative to uncased DMWs. Despite the effects of borehole flow, salinity measurements in DMWs may be useful for observing long-term trends in thickness of the upper part of the transition zone by monitoring the depth of the apparent midpoint of the transition zone between freshwater and saltwater. An understanding of borehole flow is critically important for proper interpretation of salinity profiles and evaluation of the amount of fresh groundwater that can be developed for future needs.

\section{References Cited}

Andrews, C.B., 1909, The structure of the southeastern portion of the island of Oahu: Terre Haute, Indiana, Rose Polytechnic Institute, Master's thesis, $18 \mathrm{p}$.

Badon Ghyben, W., 1889, Nota in verband met de voorgenomen putboring nabij Amsterdam: Tijdschrift van het Koninklijk Instituut van Ingenieurs, p. 8-22.

Bredehoeft, J.D., and Papadopulos, I.S., 1965, Rates of vertical groundwater movement estimated from the Earth's thermal profile: Water Resources Research, v. 1, no. 2, p. 325-328.

Britt, S.L., 2005, Testing the in-well horizontal laminar flow assumption with a sand-tank well model: Ground Water Monitoring \& Remediation, v. 25, no. 3, p. 73-81.
Cartwright, K., 1970, Groundwater discharge in the Illinois Basin as suggested by temperature anomalies: Water Resources Research, v. 6, no. 3, p. 912-918.

Chung, S.-O., Lau, L.S., Liu, C.C.K., and Gee, H.K., 1982, Formation of transition zone in a basal aquifer under pumping stresses: University of Hawai ' $i$, Water Resources Research Center Technical Memorandum Report 66, 21 p, accessed March 17, 2010 at http://scholarspace.manoa. hawaii.edu/handle/10125/2646.

Church, P.E., and Granato, G.E., 1996, Bias in ground-water data caused by well-bore flow in long-screen wells: Ground Water, v. 34, no. 2, p. 262-273.

Clesceri, L.S., Greenberg, A.E., and Eaton, A.D., 1998, Standard methods for the examination of water and wastewater (20th ed.): Washington, D.C., American Public Health Association, $1220 \mathrm{p}$.

Cooper, H.H., Jr., 1959, A hypothesis concerning the dynamic balance of fresh water and salt water in a coastal aquifer: Journal of Geophysical Research, v. 64, p. 461-467.

Corcho Alvarado, J.A., Barbecot, F., and Purtschert, R., 2009, Ambient vertical flow in long-screen wells; a case study in the Fontainebleau Sands Aquifer (France): Hydrogeology Journal, v. 17, no. 2, p. 425-431.

Cox, D.C., 1954, Shape of the mixing curve in a GhybenHerzberg lens, in Hawaiian Academy of Science Proceedings, 29th Annual Meeting, Honolulu, Hawai 'i.

Cox, D.C., and Lao, C., 1967, Development of deep monitoring stations in the Pearl Harbor ground water area on Oahu: University of Hawai' $i$, Water Resources Research Center Technical Report 4, 34 p.

Doell, R.R., and Dalrymple, G.B., 1973, Potassium-argon ages and paleomagnetism of the Waianae and Koolau Volcanic Series, Oahu, Hawaii: Geological Society of America Bulletin, v. 84, no. 4, p. 1217-1242.

Drury, M.J., 1984, Perturbations to temperature gradients by water flow in crystalline rock formations: Tectonophysics, v. 103, nos. 1-4, p. 19-32.

Drury, M.J., and Jessop, A.M., 1982, The effect of a fluidfilled fracture on the temperature profile in a borehole: Geothermics, v. 11, no. 3, p. 145-152.

Elci, A., Molz, F.J., III, and Waldrop, W.R., 2001, Implications of observed and simulated ambient flow in monitoring wells: Ground Water, v. 39, no. 6, p. 853-862.

Elci, A., Gregory, P.F., and Molz, F.J., 2003, Detrimental effects of natural head gradients on chemical and water level measurements in observation wells; identification and control: Journal of Hydrology, v. 281, nos. 1-2, p. 70-81. 
Engott, J.A., and Vana, T.T., 2007, Effects of agricultural land-use changes and rainfall on ground-water recharge in central and west Maui, Hawai 'i, 1926-2004: U.S. Geological Survey Scientific Investigations Report 2007-5103, 56 p. (Also available at http://pubs.usgs.gov/sir/2007/5103/.)

Eyre, P.R., 1983, The effects of pumpage, irrigation return, and regional ground-water flow on the water quality at Waiawa water tunnel, Oahu, Hawaii: U.S. Geological Survey WaterResources Investigations Report 83-4097, 49 p. (Also available at http://pubs.er.usgs.gov/usgspubs/wri/wri834097.)

Eyre, P.R., 1987, Source of salts in the Waianae part of the Pearl Harbor aquifer near Barbers Point water tunnel, Oahu, Hawaii: U.S. Geological Survey Water-Resources Investigations Report 87-4247, 48 p. (Also available at http://pubs.er.usgs.gov/ usgspubs/wri/wri874247.)

Fritsch, F.N., and Carlson, R.E., 1980, Monotone piecewise cubic interpolation: Society for Industrial and Applied Mathematics Journal on Numerical Analysis, v. 17, no. 2, p. 238-246.

Giambelluca, T.W., Lau, L.S., Fok, Y.S., and Schroeder, T.A., 1984, Rainfall frequency study for Oahu: State of Hawai' $i$ Department of Land and Natural Resources, Division of Water and Land Development, Report R73, 232 p.

Giambelluca, T.W., Nullet, M.A., and Schroeder, T.A., 1986, Rainfall Atlas of Hawai' $i$ : State of Hawai'i Department of Land and Natural Resources, Division of Water and Land Development Report R76, 267 p.

Giddings, T., 1987, What is an adequate screen length for monitoring wells? Opinion 1: Ground Water Monitoring \& Remediation, v. 7, no. 2, p. 96-97.

Gingerich, S.B., 2008, Ground-water availability in the Wailuku area, Maui, Hawai ‘i: U.S. Geological Survey Scientific Investigations Report 2008-5236, 95 p. (Also available at http:// pubs.usgs.gov/sir/2008/5236/.)

Gingerich, S.B., and Oki, D.S., 2000, Ground water in Hawaii: U.S. Geological Survey Fact Sheet 126-00, 6 p. (Also available at http://pubs.usgs.gov/fs/2000/126.)

Glover, R.E., 1959, The pattern of fresh-water flow in a coastal aquifer: Journal of Geophysical Research, v. 64, no. 4, p. 457-459.

Hanson, R.T., 2005, The significance of wellbore flow in the Santa Clara Valley, California [abs.]: Eos (American Geophysical Union Transactions), v. 86 (52) Fall meeting supplement, abs. H13L-01.

Hanson, R.T., Everett, R.R., Newhouse, M.W., Crawford, S.M., Pimentel, M.I., and Smith, G.A., 2002, Geohydrology of a deep-aquifer system monitoring-well site at Marina, Monterey County, California: U.S. Geological Survey Water-Resources Investigations Report 2002-4003, 73 p. (Also available at http:// pubs.usgs.gov/wri/wri024003/.)
Hayashi, M., 2004, Temperature-electrical conductivity relation of water for environmental monitoring and geophysical data inversion: Environmental Monitoring and Assessment, v. 96, nos. 1-3, p. 119-128.

Helsel, D.R., and Hirsch, R.M., 1992, Statistical methods in water resources: Amsterdam, The Netherlands, Elsevier, 522 p.

Herzberg, A., 1901, Die Wasserversorgung einiger Nordseebāder: Journal fūr Gasbeleuchtung und Wasserversorgung, v. 44 , no. 44,45 , p. $815-819,842-844$.

Hubbert, M.K., 1940, The theory of ground-water motion: The Journal of Geology, v. 48, no. 8, p. 785-944.

Hunt, C.D., Jr., 1996, Geohydrology of the island of Oahu, Hawaii: U.S. Geological Survey Professional Paper 1412-B, 55 p. (Also available at http://pubs.er.usgs.gov/usgspubs/pp/ pp1412B.)

Hutchins, S.R., and Acree, S.D., 2000, Ground water sampling bias observed in shallow, conventional wells: Ground Water Monitoring \& Remediation, v. 20, no. 1, p. 86-93.

Izbicki, J.A., Christensen, A.H., Hanson, R.T., Martin, P., Crawford, S.M., and Smith, G.A., 1999, U.S. Geological Survey combined well-bore flow and depth-dependent water sampler: U.S. Geological Survey Fact Sheet 196-99, 2 p. (Also available at http://pubs.usgs.gov/fs/1999/fs19699/.)

Izbicki, J.A., Christensen, A.H., Newhouse, M.W., Smith, G.A., and Hanson, R.T., 2005, Temporal changes in the vertical distribution of flow and chloride in deep wells: Ground Water, v. 43 , no. 4 , p. $531-544$.

Izuka, S.K., and Gingerich, S.B., 1998, Estimation of the depth to the fresh-water/salt-water interface from vertical head gradients in wells in coastal and island aquifers: Hydrogeology Journal, v. 6, no. 3, p. 365-373.

Kim, K.-Y., Seong, H., Kim, T., Park, K.-H., Woo, N.-C., Park, Y.-S., Koh, G.-W., and Park, W.-B., 2006, Tidal effects on variations of fresh-saltwater interface and groundwater flow in a multilayered coastal aquifer on a volcanic island (Jeju Island, Korea): Journal of Hydrology, v. 330, nos. 3-4, p. $525-542$.

Kim, K.-Y., Chon, C.-M., Park, K.-H., Park, Y.-S., and Woo, N.-C., 2008, Multi-depth monitoring of electrical conductivity and temperature of groundwater at a multilayered coastal aquifer; Jeju Island, Korea: Hydrological Processes, v. 22, no. 18, p. 3724-3733.

Kim, K.-Y., Park, Y.-S., Kim, G.-P., and Park, K.-H., 2009, Dynamic freshwater-saline water interaction in the coastal zone of Jeju Island, South Korea: Hydrogeology Journal, v. 17, no. 3, p. 617-629.

Konikow, L.F., and Hornberger, G.Z., 2006, Modeling effects of multinode wells on solute transport: Ground Water, v. 44, no. 5, p. 648-660. 
Lacombe, S., Sudicky, E.A., Frape, S.K., and Unger, A.J.A., 1995, Influence of leaky boreholes on cross-formational groundwater flow and contaminant transport: Water Resources Research, v. 31, no. 8, p. 1871-1882.

Langenheim, V.M., and Clague, D.A., 1987, The HawaiianEmperor volcanic chain, Part II, Stratigraphic framework of volcanic rocks of the Hawaiian Islands, chap. 1 of Decker, R.W., Wright, T.L., and Stauffer, P.H., eds., Volcanism in Hawaii: U.S. Geological Survey Professional Paper 1350, vol. 1, p. 55-84. (Also available at http://pubs.er.usgs.gov/ usgspubs/pp/pp1350.)

Lao, C., 2005, Determining island fresh water availability with deep monitor wells penetrating into salt water, in Institutions for sustainable watershed management; reconciling physical and management ecology in the Asia-Pacific: AWRA's 2006 Summer Specialty Conference, American Water Resources Association, Middleburg, Virginia, TPS-05-2.

Lao, C., Peterson, F.L., and Cox, D.C., 1969, Application of electric well logging and other well logging methods in Hawaii: University of Hawai 'i, Water Resources Research Center Technical Report 21, 108 p., accessed March 17, 2010, at http:// scholarspace.manoa.hawaii.edu/handle/10125/7603.

Lau, L.S., 1964, Research in seawater encroachment and groundwater development: Water and Sewage Works, v. 111 , no. 7, p. 308-312.

Lau, L.S., 1967, Dynamic and static studies of seawater intrusion: University of Hawai ' $i$, Water Resources Research Center Technical Report 3, 31 p., accessed March 17, 2010, at http://scholarspace.manoa.hawaii.edu/handle/10125/15245.

Lau, L.S., and Mink, J.F., 2006, Hydrology of the Hawaiian Islands: Honolulu, University of Hawai'i Press, 274 p.

Li, H.L., Li, G., Cheng, J., and Boufadel, M.C., 2007, Tideinduced head fluctuations in a confined aquifer with sediment covering its outlet at the seafloor: Water Resources Research, v. 43, p. W03404, doi:03410.01029/02005WR004724.

Lindgren, W., 1903, The water resources of Molokai, Hawaiian Islands: U.S. Geological Survey Water Supply Paper 77, 62 p. (Also available at http://pubs.er.usgs.gov/usgspubs/wsp/wsp77.)

Liu, C.C.K., 2006, Analytical groundwater flow and transport modeling for the estimation of sustainable yield of Pearl Harbor aquifer: University of Hawai' $i$, Water Resources Research Center Project Report PR-2006-06, 53 p., accessed March 17, 2010, at http://scholarspace.manoa. hawaii.edu/handle/10125/4074.

Liu, C.C.K., 2007, RAM2 modeling and determination of sustainable yields of Hawaii basal aquifers: University of Hawai 'i, Water Resources Research Center Project Report PR-2008-06, 81 p., accessed March 17, 2010, at http:// hawaii.gov/dlnr/cwrm/publishedreports/PR200806.pdf.
McDonald, J.P., and Smith, R.M., 2009, Concentration profiles in screened wells under static and pumped conditions: Ground Water Monitoring \& Remediation, v. 29, no. 2, p. 78-86.

Meinzer, O.E., 1930, Ground water in the Hawaiian Islands, in Stearns, H.T., and Clark, W.O., eds., Geology and water resources of the Kau District, Hawaii: U.S. Geological Survey Water-Supply Paper 616, p. 1-28. (Also available at http://pubs.er.usgs.gov/usgspubs/wsp/wsp616.)

Meyer, W., and Presley, T.K., 2001, The response of the Iao aquifer to ground-water development, rainfall, and land-use practices between 1940 and 1998, island of Maui, Hawaii: U.S. Geological Survey Water-Resources Investigations Report 2000-4223, 60 p. (Also available at http://pubs.usgs. gov/wri/wri00-4223/.)

Meyer, W., and Souza, W.R., 1995, Factors that control the amount of water that can be diverted to wells in a high-level aquifer, in Hermann, R., Back, W., Sidle, R.C., and Johnson, A.I., eds., Water resources and environmental hazards; emphasis on hydrologic and cultural insight in the Pacific Rim: Honolulu, Hawai 'i, Proceedings of the American Water Resources Association Annual Summer Symposium, June 25-28, p. 207-216.

Mink, J.F., 1980, State of the groundwater resources of southern Oahu: Honolulu Board of Water Supply, 83 p.

Mink, J.F., 1981, Determination of sustainable yields in basal aquifer, in Fujimura, F.N., and Chang, W.B.C., eds., Groundwater in Hawaii-a century of progress: Honolulu, University of Hawai' $i$, Water Resources Research Center, p. 101-116.

Mink, J.F., and Lau, L.S., 1990, Aquifer identification and classification for $\mathrm{O}^{\text {‘ }} \mathrm{ahu}$; groundwater protection strategy for Hawai ‘i: University of Hawai'i, Water Resources Research Center Technical Report 179, 28 p., accessed March 17, 2010, at http://scholarspace.manoa.hawaii.edu/handle/10125/1961.

Newhouse, M.W., and Hanson, R.T., 2002, Three-dimensional measurements of flow in uncased wells completed in basalt, Mountain Home Air Force Base, Idaho, March 2000: U.S. Geological Survey Water-Resources Investigations Report 2001-4259, 13 p. (Also available at http://idaho.usgs.gov/ PDF/wri014259/mhafb.pdf.)

Newhouse, M.W., Izbicki, J.A., and Smith, G.A., 2005, Comparison of velocity-log data collected using impeller and electromagnetic flowmeters: Ground Water, v. 43, no. 3, p. 434-438.

Nichols, W.D., Shade, P.J., and Hunt, C.D., Jr., 1996, Summary of the Oahu, Hawaii, regional aquifer-system analysis: U.S. Geological Survey Professional Paper 1412-A, 71 p. (Also available at http://pubs.er.usgs.gov/usgspubs/pp/ pp1412A.) 
Oki, D.S., 1997, Modeling the effects of pumping, barometric pressure and ocean tides on ground-water levels in northern Oahu, Hawaii: Honolulu, University of Hawai 'i, Ph.D. dissertation, $321 \mathrm{p}$.

Oki, D.S., 1998, Geohydrology of the central Oahu, Hawaii, ground-water flow system and numerical simulation of the effects of additional pumping: U.S. Geological Survey Water-Resources Investigations Report 97-4276, 132 p. (Also available at http://pubs.er.usgs.gov/usgspubs/wri/ wri974276.)

Oki, D.S., 2002, Reassessment of ground-water recharge and simulated ground-water availability for the Hawi area of north Kohala, Hawaii: U.S. Geological Survey WaterResources Investigations Report 2002-4006, 62 p. (Also available at http://pubs.usgs.gov/wri/wri02-4006/.)

Oki, D.S., 2005, Numerical simulation of the effects of low-permeability valley-fill barriers and the redistribution of ground-water withdrawals in the Pearl Harbor area, Oahu, Hawaii: U.S. Geological Survey Scientific Investigations Report 2005-5253, 111 p. (Also available at http://pubs. usgs.gov/sir/2005/5253/.)

Oki, D.S., and Meyer, W., 2001, Analytical versus numerical estimates of water-level declines caused by pumping, and a case study of the Iao Aquifer, Maui, Hawaii: U.S. Geological Survey Water-Resources Investigations Report 20004244, 31 p. (Also available at http://pubs.usgs.gov/wri/ wri00-4244/.)

Oki, D.S., and Presley, T.K., 2008, Causes of borehole flow and effects on vertical salinity profiles in coastal aquifers, in 20th Salt Water Intrusion Meeting, Naples, Florida, USA, June 23-27, 2008, Proceedings, p. 170-173.

Oki, D.S., Souza, W.R., Bolke, E.L., and Bauer, G.R., 1998, Numerical analysis of the hydrogeologic controls in a layered coastal aquifer system, Oahu, Hawaii, USA: Hydrogeology Journal, v. 6, no. 2, p. 243-263.

Paillet, F.L., and Hess, A.E., 1995, Geophysical log data from basalt aquifers near Waipahu on the island of Oahu and Pahoa on the island of Hawaii, Hawaii: U.S. Geological Survey Open-File Report 95-383, 62 p. (Also available at http://pubs.er.usgs.gov/usgspubs/ofr/ofr95383.)

Paillet, F.L., Williams, J.H., Oki, D.S., and Knutson, K.D., 2002, Comparison of formation and fluid-column logs in a heterogeneous basalt aquifer: Ground Water, v. 40, no. 6, p. 577-585.

Palmer, H.S., 1927, The geology of the Honolulu artesian system: Honolulu Sewer and Water Commission, 68 p.

Peterson, F.L., 1972, Water development on tropic volcanic islands, type example-Hawaii: Ground Water, v. 10, no. 5 , p. 18-23.
Peterson, F.L., 1993, Hydrogeology of volcanic oceanic islands, in Sakura, Y., ed., Selected papers on environmental hydrogeology—hydrogeology, selected paper 4, IAH: Hannover, Heise, p. 163-171.

Peterson, F.L., and Lao, C., 1970, Electric well logging of Hawaiian basaltic aquifers: Ground Water, v. 8, no. 2, p. 11-18.

Peterson, F.L., and Seghal, M.M., 1974, Determining porosity with neutron logs from Hawaiian basaltic aquifers: University of Hawai 'i, Water Resources Research Center Technical Report 80, 37 p., accessed March 17, 2010, at http://scholarspace.manoa.hawaii.edu/handle/10125/15112.

Presley, T.K., and Oki, D.S., 1996, Drilling, construction, and caliper-log data for wells 3-3406-14 and -15, Helemano exploratory wells I and II, Oahu, Hawaii: U.S. Geological Survey Open-File Report 96-425, 14 p. (Also available at http://pubs.er.usgs.gov/usgspubs/ofr/ofr96425.)

Presley, T.K., Sinton, J.M., and Pringle, M., 1997, Postshield volcanism and catastrophic mass wasting of the Waianae Volcano, Oahu, Hawaii: Bulletin of Volcanology, v. 58, p. 597-616.

Reilly, T.E., Franke, O.L., and Bennett, G.D., 1989, Bias in groundwater samples caused by wellbore flow: Journal of Hydraulic Engineering, v. 115, no. 2, p. 270-276.

Robbins, G.A., 1989, Influence of using purged and partially penetrating monitoring wells on contaminant detection, mapping, and modeling: Ground Water, v. 27, no. 2, p. 155-162.

Rotzoll, K., 2007, Hydraulic parameter estimation using aquifer tests, specific capacity, ocean tides, and wave setup for Hawai 'i aquifers: Honolulu, University of Hawai 'i, Ph.D dissertation, 160 p., accessed July 09, 2010, at http://www. soest.hawaii.edu/asp/GG/academics/theses/Rotzoll_2007_ Dissertation_hi.pdf.

Rotzoll, K., and El-Kadi, A.I., 2007, Numerical ground-water flow simulation for Red Hill fuel storage facilities, NAVFAC Pacific, Oahu, Hawaii: University of Hawai 'i, Water Resources Research Center, prepared for TEC Inc., $74 \mathrm{p}$.

Rotzoll, K., and El-Kadi, A.I., 2008, Estimating hydraulic properties of coastal aquifers using wave setup: Journal of Hydrology, v. 353, nos. 1-2, p. 201-213.

Rotzoll, K., El-Kadi, A.I., and Gingerich, S.B., 2008, Analysis of an unconfined aquifer subject to asynchronous dual-tide propagation: Ground Water, v. 46, no. 2, p. 239-250.

Rotzoll, K., Oki, D.S., and El-Kadi, A.I., 2010, Changes of freshwater-lens thickness in basaltic island aquifers overlain by thick coastal sediments: Hydrogeology Journal, v. 18, no. 6 , p. $1425-1436$ 
Shalev, E., Lazar, A., Wollman, S., Kington, S., Yechieli, Y., and Gvirtzman, H., 2009, Biased monitoring of fresh water-salt water mixing zone in coastal aquifers: Ground Water, v. 47, no. 1, p. 49-56.

Shosky, D.J., Jr., 1987, What is an adequate screen length for monitoring wells? Opinion 2: Ground Water Monitoring \& Remediation, v. 7, no. 2, p. 98-103.

Sorey, M.L., 1971, Measurement of vertical groundwater velocity from temperature profiles in wells: Water Resources Research, v. 7, no. 4, p. 963-970.

Souza, W.R., and Meyer, W., 1995, Numerical simulation of regional changes in ground-water levels and in the freshwater-saltwater interface induced by increased pumpage at Barbers Point Shaft, Oahu, Hawaii: U.S. Geological Survey Water-Resources Investigations Report 95-4206, 47 p. (Also available at http://pubs.er.usgs.gov/usgspubs/wri/wri954206.)

Souza, W.R., and Voss, C.I., 1987, Analysis of an anisotropic coastal aquifer system using variable-density flow and solute transport simulation: Journal of Hydrology, v. 92, no. 1, p. 17-41.

Spane, F.A., 2002, Considering barometric pressure in groundwater flow investigations: Water Resources Research, v. 38, no. 6, p. 1078, doi:1010.1029/2001WR000701.

Stallman, R.W., 1963, Computation of ground-water velocity from temperature data, in Bentall, R., ed., Methods of collecting and interpreting ground-water data: U.S. Geological Survey Water Supply Paper, 1544-H, p. 36-46. (Also available at http://pubs.er.usgs.gov/usgspubs/wsp/wsp1544H.)

Stearns, H.T., 1940, Supplement to the geology and groundwater resources of the island of Oahu, Hawaii: Hawai 'i Division of Hydrography Bulletin 5, 164 p.

Stearns, H.T., 1941, Salt-water invasion in Hawaii, in U.S. Geological Survey Conference on the ground water division, April 28-May 3, 1941, 8 p.

Stearns, H.T., and Macdonald, G.A., 1942, Geology and groundwater resources of the island of Maui, Hawaii: Hawai' $i$ Division of Hydrography Bulletin 7, 334 p.

Stearns, H.T., and Vaksvik, K.N., 1935, Geology and groundwater resources of the island of Oahu, Hawaii: Hawai ' $\mathrm{i}$ Division of Hydrography Bulletin 1, 479 p.

Sukop, M.C., 2000, Estimation of vertical concentration profiles from existing wells: Ground Water, v. 38, no. 6, p. 836-841.

Takasaki, K.J., and Mink, J.F., 1985, Evaluation of major dikeimpounded ground-water reservoirs, island of Oahu: U.S. Geological Survey Water-Supply Paper 2217, 77 p. (Also available at http://pubs.er.usgs.gov/usgspubs/wsp/wsp2217.)

TEC Inc., 2007, Red Hill bulk fuel storage facility final technical report, Pearl Harbor, Hawaii: Prepared for Department of the Navy, Naval Facilities Engineering Command, Pacific Contract Number N62742-02-D-1802, CTO 007, 168 p.
Tóth, J., 1962, A theory of groundwater motion in small drainage basins in central Alberta, Canada: Journal of Geophysical Research, v. 67, no. 11, p. 4375-4387.

U.S. Environmental Protection Agency, 2006, Secondary drinking water regulations; guidance for nuisance chemicals: U.S. Environmental Protection Agency, accessed March 17, 2010, at http://www.epa.gov/safewater/consumer/2ndstandards.html.

U.S. Geological Survey, variously dated, National field manual for the collection of water-quality data: U.S. Geological Survey Techniques of Water-Resources Investigations book 9, chaps. A1-A9, accessed March 17, 2010, at http://pubs.water. usgs.gov/twri9A.

Underwood, M.R., Meyer, W., and Souza, W.R., 1995, Groundwater availability from the Hawi aquifer in the Kohala area, Hawaii: U.S. Geological Survey Water-Resources Investigations Report 95-4113, 57 p. (Also available at http://pubs. er.usgs.gov/usgspubs/wri/wri954113.)

Visher, F.N., and Mink, J.F., 1964, Ground-water resources in southern Oahu, Hawaii: U.S. Geological Survey Water Supply Paper 1778, 133 p. (Also available at http://pubs.er.usgs. gov/usgspubs/wsp/wsp1778.)

Voss, C.I., and Souza, W.R., 1987, Variable density flow and solute transport simulation of regional aquifers containing a narrow freshwater-saltwater transition zone: Water Resources Research, v. 23, no. 10, p. 1851-1866.

Voss, C.I., and Wood, W.W., 1994, Synthesis of geochemical, isotopic and groundwater modeling analysis to explain regional flow in a coastal aquifer of southern Oahu, Hawaii, in Proceedings of Mathematical models and their applications to isotope studies in groundwater hydrology, International Atomic Energy Agency, Vienna, Austria, June 1-4, 1993, p. 147-178.

Wentworth, C.K., 1938, Geology and ground-water resources of the Palolo-Waialae district: Honolulu Board of Water Supply, 274 p.

Wentworth, C.K., 1942, Storage consequences of the GhybenHerzberg theory: American Geophysical Union Transactions, v. 23, p. 683-693.

Wentworth, C.K., 1947, Factors in the behavior of groundwater in a Ghyben-Herzberg system: Pacific Science, v. 1, no. 3, p. 172-184.

Wentworth, C.K., 1948, Growth of the Ghyben-Herzberg transition zone under a rinsing hypothesis: American Geophysical Union Transactions, v. 29, no. 1, p. 97-98.

Wentworth, C.K., 1951, Geology and ground-water resources of the Honolulu-Pearl Harbor area, Oahu, Hawaii: Honolulu Board of Water Supply, 111 p.

Zinn, B.A., and Konikow, L.F., 2007, Effects of intraborehole flow on groundwater age distribution: Hydrogeology Journal, v. 15 , no. 4 , p. 633-643. 
Produced in the Western Region, Menlo Park, California Manuscript approved for publication, March 15, 2010

Text edited by Peter H. Stauffer

Layout and design by Jeanne S. DiLeo 
